\title{
56. PALEOGENE GLACIAL HISTORY OF ANTARCTICA IN LIGHT OF LEG 120 DRILLING RESULTS ${ }^{1}$
}

\author{
Sherwood W. Wise, Jr., ${ }^{2}$ James R. Breza, ${ }^{2,3}$ David M. Harwood, ${ }^{4}$ Wuchang Wei, ${ }^{2}$ and James C. Zachos ${ }^{5}$
}

\begin{abstract}
The Paleogene glacial history of Antarctica has been inferred largely from indirect evidence of glaciation gathered from the oceans beyond that remote, ice-shrouded, and inhospitable continent. This evidence includes the "proxy" stable isotopic record from the world's oceans; the occurrence of ice-rafted debris (IRD) in the Southern Ocean; inflections in sea-level curves; the presence of hiatuses in the deep-sea record; and changes in clay mineral assemblages, in the diversities of microfossil assemblages, and in the steepness of latitudinal biotic gradients. Ocean Drilling Program Leg 120 has added an important dimension to this growing body of evidence through the discovery of lowest Oligocene IRD at Site 748 on the Southern Kerguelen Plateau at a record distance north of the Antarctic continent $\left(58^{\circ} \mathrm{S}\right.$ latitude) and within a pelagic biosiliceous-carbonate ooze sequence that has yielded a complementary oxygen isotope record of the cryospheric event. We deduce that an ice sheet reached sea level during the earliest Oligocene (35.8-36.0 Ma) and that the effect was immediate and profound. In addition to the IRD, this event was manifested at Site 748 by a dramatic cooling of the surface waters surrounding the continent as indicated by a sharp increase in the percentage of cold-water calcareous nannoplankton, an increase in planktonic foraminiferal $\delta^{18} \mathrm{O}$ values, and an increase in the percentage of biosiliceous material in the sediment. The temperature of the bottom waters over the plateau also decreased, and the volume of ice on the continent increased.

We have reviewed the accumulated evidence from this and other investigations of the past two decades on and around Antarctica, and have concluded that ice sheets were present on the continent during the Oligocene, including the earliest Oligocene. Not necessarily permanent features, they probably went through many advances and contractions and may have disappeared completely at times. The rapid ice advance during the earliest Oligocene reached sea level at several widely scattered localities around the continent, but only for a brief period of time at some of these localities. Differences of opinion among investigators concern primarily the size and persistence of the Oligocene ice sheet(s).

Tantalizing evidence of undated till deposits subjacent to well-dated Oligocene glaciomarine sequences along the Antarctic margin and possible occurrences of IRD beyond suggest the presence of glaciers during the late Eocene and possibly even during the early-middle Eocene. Included among the studies in this Scientific Results volume are new age calibrations from Eltanin piston cores taken at relatively low latitudes ( $38^{\circ}$ to $58^{\circ} \mathrm{S}$ ) in the southeast Pacific from which Eocene IRD has been reported. There is little agreement, however, among investigators as to whether an ice sheet was present at any time during the Eocene, particularly during early-middle Eocene times.
\end{abstract}

\section{INTRODUCTION}

A major discovery of Ocean Drilling Program (ODP) Leg 120 to the Kerguelen Plateau was the occurrence of lowest Oligocene ice-rafted debris (IRD) at $58^{\circ} \mathrm{S}$ latitude, a record distance from the Antarctic continent (Breza et al., 1988, 1989; Schlich, Wise, et al., 1989; Breza and Wise, this volume). The IRD occurred within a pelagic carbonate ooze sequence that yielded a complementary stable isotope record of the cryospheric event (Zachos et al., 1989, this volume). This discovery has important implications for the interpretation of the Cenozoic glacial history of Antarctica, particularly the history of ice sheets on that continent. The purpose of this synthesis is to discuss these implications in view of other exploratory efforts over the past 2 decades that have sought to elucidate Paleogene glacial history.

\footnotetext{
${ }^{1}$ Wise, S. W., Jr., Schlich, R., et al., 1992. Proc. ODP, Sci. Results, 120: College Station, TX (Ocean Drilling Program).

2 Department of Geology, Florida State University, Tallahassee, FL 32306, U.S.A.

${ }^{3}$ New address: Woodward-Clyde Consultants, 3676 Hartsfield Plaza, Tallahassee, FL 32303, U.S.A.

${ }^{4}$ Department of Geology, 214 Bessey Hall, University of NebraskaLincoln, Lincoln, NE 68588-0340, U.S.A.

5 Department of Geological Sciences, 1006 C. C. Little Building, University of Michigan, Ann Arbor, MI 48109-1063, U.S.A.
}

An understanding of the glacial history of Antarctica is fundamental to understanding the forces and processes that have determined climate change on this planet during much of the Cenozoic. Today, the presence and extent of the Antarctic ice sheet exert a dominant control on global atmospheric and oceanic circulation patterns through its influence on ocean surface temperatures; the albedo effect of its ice surface; the production of dense, cold oceanic bottom waters; its influence on precipitation and evaporation; and the effect of the ice margin on the position of the subpolar zone and its associated eastward-moving depression systems (Kemp, 1978; Webb, 1990). Expansions and contractions of the polar ice margin may have led to shifts in the position of the circumpolar zonal westerlies, thereby narrowing or expanding the equatorial Trade Wind zone (Kemp, 1978).

Little of the history of the Antarctic ice sheet, however, can be read directly from the limited geologic record of that continent, $98 \%$ of which is buried under the present-day ice carapace. Instead, it has been necessary, for the most part, to read the history of Antarctic glaciation indirectly from the more accessible and complete sedimentary and paleobiological record of the adjacent Southern Ocean through such indexes as the occurrence of IRD or changes in the nature of the sediments and in the diversity of the pelagic calcareous and siliceous microfossil assemblages that make up much of those sediments. Antarctic cryospheric history can also be read, albeit more indirectly, from the stable isotope record of 
the world's oceans, and from changes in eustatic sea levels recorded along continental margins or on carbonate banks or atolls of the tropical latitudes. In some instances hiatuses in ocean basin sediments can be tied to cryospheric events.

All of these indirect or proxy indicators of Antarctic glacial history are subject to widely varying interpretations and, hence, have long provided fertile ground for spirited debate and controversy (Mercer, 1983). In recent years, therefore, greater efforts on an international scale have been made to obtain more direct physical evidence of Antarctic glacial history. During the past $5 \mathrm{yr}$, major initiatives have included four ODP cruises to the Southern Ocean (Legs 113, 114, 119, and 120 ) in addition to land expeditions in search of evidence for the older (pre-Quaternary) glacial history. The key questions to be answered are:

1. When did a Cenozoic continental ice sheet first form on Antarctica?

2. Once formed, was it a permanent feature? If not, what is the timing of the glacial/preglacial phases?

3. What has been its nature at various times: "temperate" or "polar" ice?

As a result of this new surge of exploration, detailed glacial histories have been written for various regions (e.g., Barrett et al., 1989; Barron, Larsen, et al., 1989; Kennett and Barker, 1990; Barron et al., 1991a). A comprehensive summary of these studies will not be rendered here. Instead, we wish to place the Leg 120 drilling results and associated studies reported in this volume in a historical context so that we can relate them to two main issues: (1) the existence and extent of a continental ice sheet(s) during the early Oligocene, and (2) the existence and extent of glacial ice on Antarctic during the Eocene.

\section{PALEOGENE GLACIATION}

With the discovery of 25-m.y. old (upper Oligocene) and younger glaciomarine sediments in the Ross Sea during Deep Sea Drilling Project (DSDP) Leg 28 in 1973 (Hayes, Frakes, et al., 1975), it became clear that the Cenozoic glacial history of Antarctica extended well back into the Tertiary. This evidence was in accord with an earlier report of Paleogene hyaloclastite rocks erupted under ice in Marie Byrd Land (now dated at about $25 \mathrm{Ma}$; LeMasurier and Rex, 1982, 1983). Thus, it was demonstrated that the Pliocene/Quaternary "Ice Age" of the Northern Hemisphere is but a latter-day manifestation of a major glacial episode in Earth history that had begun in the Southern Hemisphere tens of millions of years earlier (Kennett, 1977, and references therein).

The Leg 28 drill site (DSDP 270; Fig. 1) had been located well out into the Ross Sea, off the edge of the present Ross Ice Shelf. High sedimentation rates and the presence of a predominantly Nothofagus (Southern Beech) palynomorph assemblage within the upper Oligocene glacial sequence led Kemp and Barrett (1975, p. 508) to envision "an environment with wet-based, 'temperate' glaciers calving bergs into a relatively open sea; by contrast, periods of intense cold, with the major development of ice shelves are distinguished by slow sedimentation and erosion by currents beneath the ice." They hypothesized that a limited vegetation of beech forests persisted through the Oligocene in coastal enclaves between glaciers that reached sea level from Marie Byrd Land.

Immediately after the discovery in the Ross Sea of direct physical evidence of late Oligocene glacial activity on Antarctica, DSDP Leg 29 recovered long Cenozoic carbonate sections at Sites 277, 279 and 281 to the north on the Campbell Plateau and South Tasman Rise (Fig. 1), which yielded the first detailed stable isotopic deep-sea record from the subant-

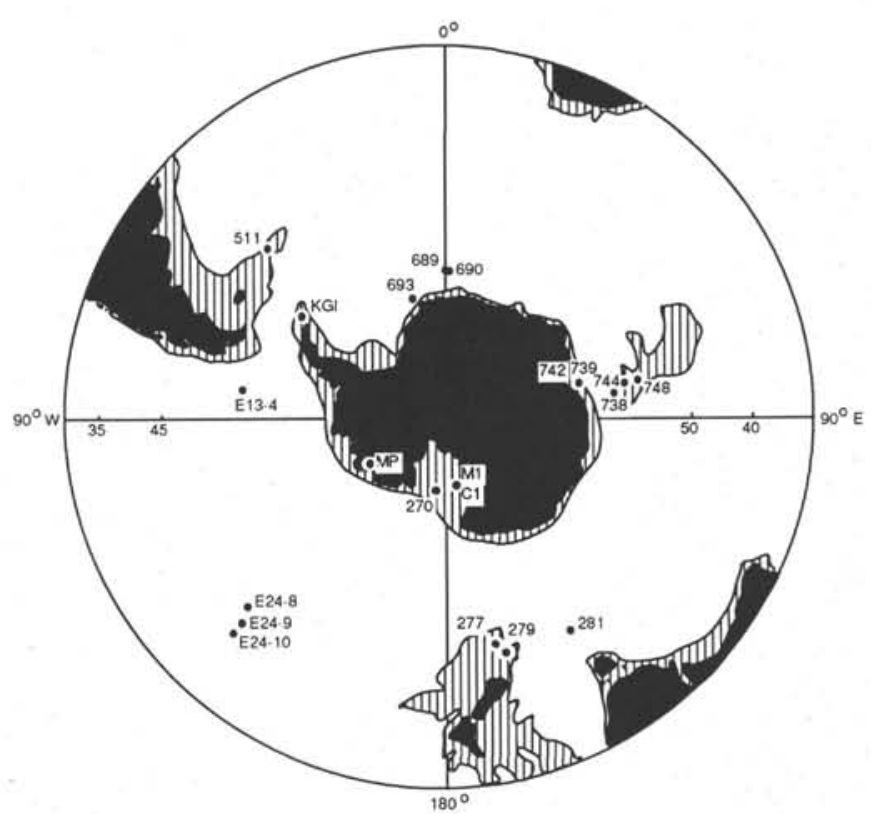

Figure 1. Location of drill sites and outcrop localities discussed in this paper. $\mathrm{Cl}=\mathrm{CIROS}-1, \mathrm{E}=$ Eltanin, $\mathrm{KGI}=$ King George Island, $\mathrm{M1}$ $=$ MSSTS-1, MP $=$ Mt. Petras.

arctic (Fig. 2, after Shackleton and Kennett, 1975). These records indicated that in concert with the final dispersal of the Gondwana continents and the concomitant thermal isolation of Antarctica (Kennett, 1977), surface temperatures had declined during the Cenozoic in a series of steps from very high values in the early Eocene.

The most prominent of these steps was in the earliest Oligocene, not the middle or late Oligocene as the Leg 28 drilling results might have indicated. Because the cooling event was also mirrored in the benthic foraminifer oxygen isotopic record, Shackleton and Kennett (1975) thought that the profound change in the cryosphere indicated that a major threshold had been crossed in the evolution of Cenozoic climate. Kennett and Shackleton (1976) reasoned that it signaled the production of cold bottom waters in the high southern latitudes, which in turn led to the development of a two-layered, "psychrospheric'" ocean (Brunn, 1957; Benson, 1975), at least on a permanent basis. ${ }^{6}$ Kennett and Shackleton (1976) attributed this event to major cryospheric development that resulted in the initial formation of sea ice around Antarctica. Although Shackleton and Kennett (1975) believed that Antarctica was heavily glaciated during Oligocene times, the ice would have been in the form of mountain glaciers, not an ice sheet. They did not believe that a permanent ice sheet formed until middle Miocene times, as indicated by another major positive inflection in their isotopic curves (Fig. 2).

Savin et al. (1975) published similar conclusions based on their interpretation of tropical Pacific isotopic records. Calculating paleotemperatures for an "ice-free" Oligocene world, both groups suggested that the earliest Oligocene oceanic

\footnotetext{
${ }^{6}$ Benson et al. (1985) maintained that the psychrosphere developed earlier (at ca. $40 \mathrm{Ma}$ ), as indicated by faunal turnover, diversification, and modernization of benthic ostracode assemblages. Thomas (1990, in press) drew a similar conclusion based on her analysis of high-latitude benthic foraminifer assemblages. On the basis of new isotopic data from ODP Leg 113, Kennett and Stott (1990) have developed a model for a three-layered Oligocene ocean ("Protooceanus") and a two-layered thermospheric one ("Proteus") for the PaleoceneEocene.
} 


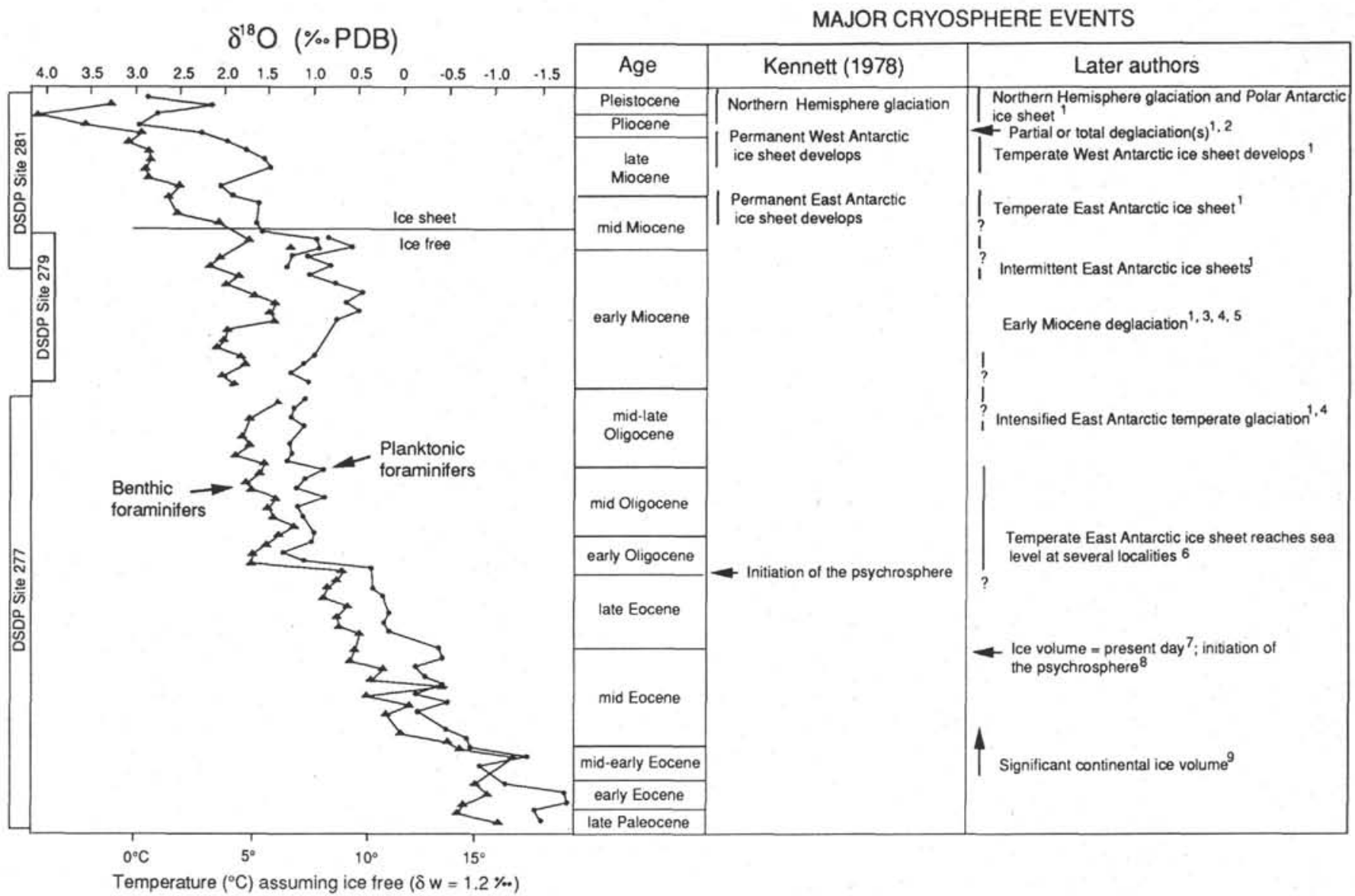

Figure 2. Oxygen isotopic curves for planktonic and benthic foraminifers from subantarctic DSDP Sites 277, 279, and 281 (from Shackleton and Kennett, 1975) correlated with major events in the evolution of Cenozoic climate as interpreted by Kennett (1978) and various subsequent authors. 1 = Harwood et al. (in press); 2 = Breza (this volume); $3=$ Kemp and Barrett (1975); $4=$ Miller et al. (1987); $5=$ Harwood et al. (1989b); 6 = Leg 119 Shipboard Scientific Party (1988), Leg 120 Scientific Drilling Party (1988), and Barrett et al. (1989); $7=$ Prentice and Matthews (1988); 8 = Benson (1975) and Benson et al. (1985); 9 = Matthews and Poore (1980) and Prentice and Matthews (1988); $10=$ IRD reported by Ehrmann (1991) but considered in this paper to be Neogene downhole contaminants.

temperatures were comparable with those of the present day at their respective sites. Savin et al. (1975) and Savin (1977) considered the values in the tropical Pacific too warm for the formation of sea ice around Antarctica, but Shackleton and Kennett (1975) extrapolated an earliest Oligocene surfacewater paleotemperature of about $0^{\circ} \mathrm{C}$ for waters along the margins of Antarctica, sufficient in their estimation to allow the formation of sea ice.

Although the above authors agreed in principle, their paleoenvironmental reconstructions diverged somewhat. The stage was being set for deeper disagreements to come, based largely on conflicting interpretations of paleotemperatures derived from the measurements of ${ }^{18} \mathrm{O} /{ }^{16} \mathrm{O}$ ratios. Although the oxygen isotopic compositions of skeletal calcite secreted by organisms vary with temperature, conflicting interpretations of oxygen isotopic paleotemperatures arise because several poorly constrained assumptions must be made. In addition, there are pitfalls in obtaining proper sample material. These problems are discussed in some detail by Shackleton and Kennett (1975), and more recently by Mix and Ruddiman (1984) and Mix (1987), and will only be outlined here.

To make useful measurements for paleotemperatures, one must first ensure that there has been no diagenetic alteration of the calcite, either by postdepositional overgrowths or by dissolution. The condition of the material is usually checked via the scanning electron microscope (SEM). Next', one must assume that the organism being measured secreted calcite in equilibrium with ocean water; if not, an estimate must be made of any biologic effect, the so-called "vital effect." For planktonic foraminifers, an estimate must also be made of the average water depth at which the species lived, because temperature varies considerably with depth in the upper $600 \mathrm{~m}$ of the oceans. Seasonality for certain species might also have to be considered as water temperatures vary by season.

The most difficult factor to constrain is, in most cases, the isotopic composition of the seawater in which the organism lived. This varies locally with excessive rainfall or evaporation (during evaporation, the lighter ${ }^{16} \mathrm{O}$ evades preferentially to the atmosphere at a greater rate), or it can vary globally if precipitation over the polar regions develops an ice sheet. This process locks up more of the lighter isotope on the continent(s) to leave the oceans enriched in ${ }^{18} \mathrm{O}$. This creates an "ice-volume effect" that makes oceanic isotopic values more "positive." The isotopic composition of ice sheets is not constant, however, and becomes increasingly more "negative" during glacial buildups. The largest ice sheet today, which is on Antarctica, is the most negative. Thus, models of ice-sheet isotopic composition must be constructed if one is to estimate the ice-volume component (see discussion by Shackleton and Kennett, 1975). In view of the wide latitude of 


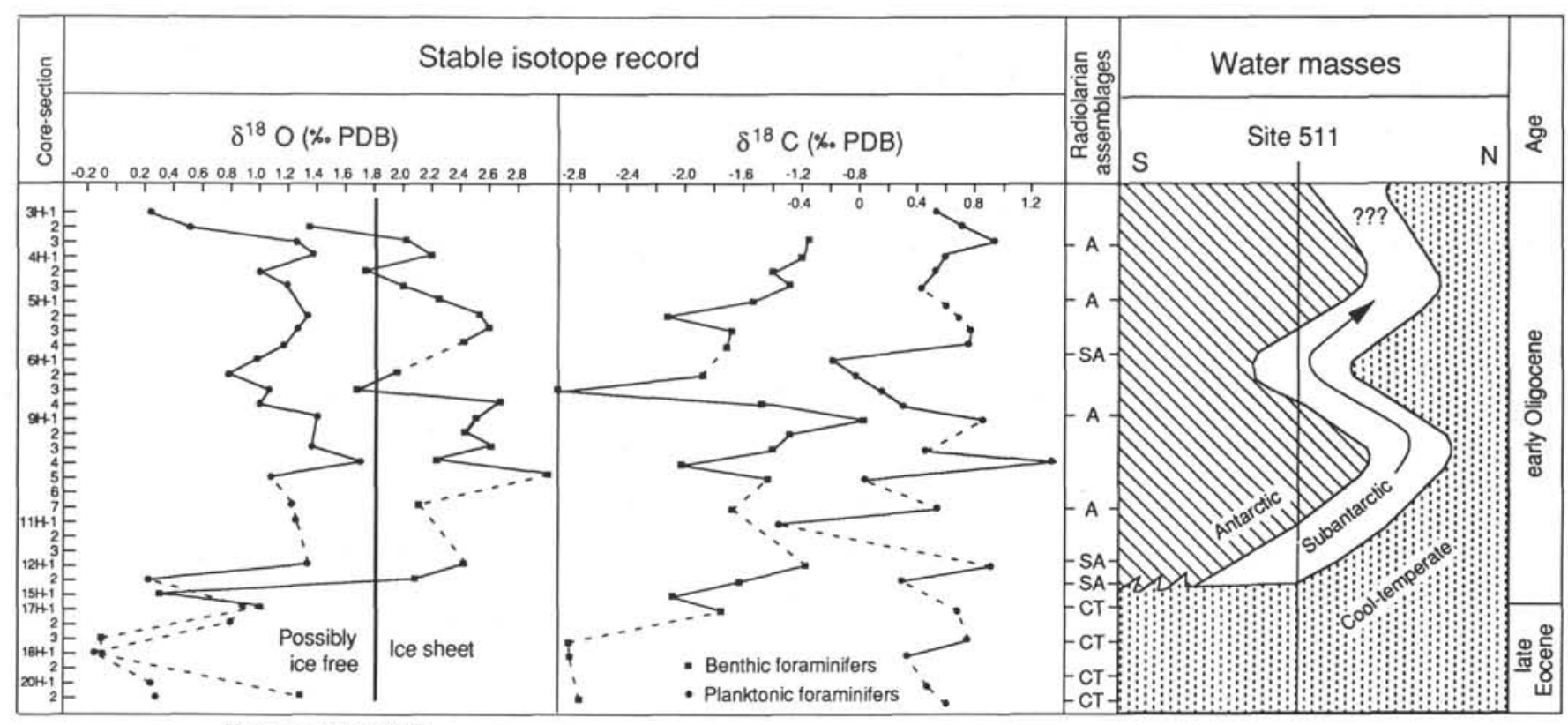

Temperature $\left({ }^{\circ} \mathrm{C}\right)$

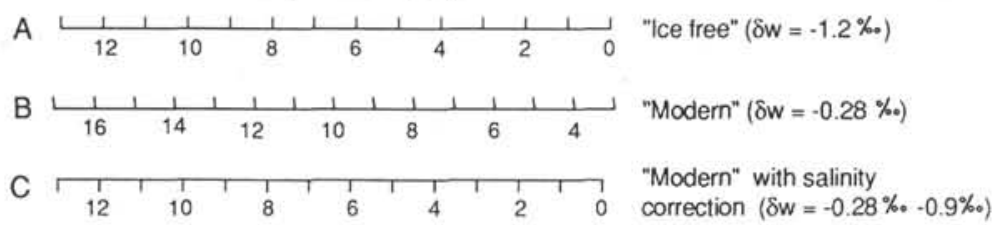

Figure 3. Correlation of stable isotope record, radiolarian assemblages, and inferred water masses for upper Eocene-lower Oligocene interval of Site 511 (after Wise et al., 1985). The vertical line drawn through $1.8 \%$ delineates times when ice sheets were probably present in the world, according to Miller et al. (1987). The upper paleotemperature scale (A) assumes no significant ice sheets, the middle scale (B) assumes an ice volume equivalent to modern values (cf. with Miller et al. curve in Fig. 13 below), and the bottom scale (C) contains a correction for ice volume and salinity.

interpretations that can be made from the stable isotopic record and the paucity of direct physical evidence of Paleogene glaciation to constrain speculation, it is not surprising that disagreements have developed over the time of formation of the first Cenozoic ice sheet.

\section{An Early Oligocene Antarctic Ice Sheet?}

The debate has centered on a paradox. Kemp and Barrett (1975) and others thought that the Leg 28 results indicated that ice-rafting from Antarctica had commenced during the late Oligocene, and, in apparent support of such an event, the most profound eustatic sea-level drop for the Cenozoic was dated as mid-Oligocene ( $29 \mathrm{Ma}$ ) by Vail et al. (1977). On the other hand, the most profound positive shift in the benthic foraminiferal oxygen isotope record for the entire Cenozoic occurred during the very earliest Oligocene, not mid way through that epoch (Fig. 2). This isotopic event, which was evident in earlier curves for Australia (Dorman, 1966) and New Zealand (Devereux, 1967), was eventually correlated in open-marine drill sections around the globe, including Site 511 on the Falkland Plateau (Fig. 3).

Although Kemp (1978) noted that the extent of Antarctic glaciation during the Oligocene was problematic, she indicated on her paleogeographic reconstructions limited "ice cover" over East Antarctica during the early Oligocene and an "ice cap" with evidence of sea-level ice for the late Oligocene (Kemp, 1978, figs. 6 and 7). That same year, Kennett (1978) summarized his interpretations, suggesting prolonged Antarctic glaciation during the Oligocene, the development of sea ice, but no ice sheet.
A major reinterpretation of the stable isotopic record was rendered 2 yr later by Matthews and Poore (1980), who concluded that Paleogene temperatures calculated for an "ice-free world" produced unreasonably low tropical and mid-latitude sea-surface temperatures, and that a significant ice-volume correction is necessary to yield realistic Paleogene temperature values. They felt that, in all probability, the earth has been glaciated since at least the Eocene (see also Poore and Matthews, 1984; Prentice and Matthews, 1988). For the early Oligocene, Poore and Matthews (1984) concluded that the isotopic temperatures recorded not only an ice-volume effect (which would raise the interpreted paleotemperatures), but also an influence of low salinity values in the surface-water higher latitudes (which would lower the interpreted paleotemperatures). In their estimation, a permanent ice sheet of present-day size has existed from at least the early Oligocene.

With the study of additional deep-sea drill sections and the innovation of new ways to compare multiple isotopic records, a number of other investigators agreed in principle with the suggestion by Matthews and his colleagues of the presence of a continental Paleogene ice sheet, at least at times during the Oligocene (Miller and Fairbanks, 1983; Keigwin and Keller, 1984; Hsü et al., 1984; Shackleton et al., 1984; Wise et al., 1985; Miller and Thomas, 1985; Keigwin and Corliss, 1986; Shackleton, 1986). There was no uniform agreement, however, on the magnitude of the ice-volume correction to be applied or, by inference, on the size and nature of the Antarctic ice sheet.

Of these various analyses, Miller et al. (1987) summarized the benthic foraminiferal record from the Atlantic and Pacific, 


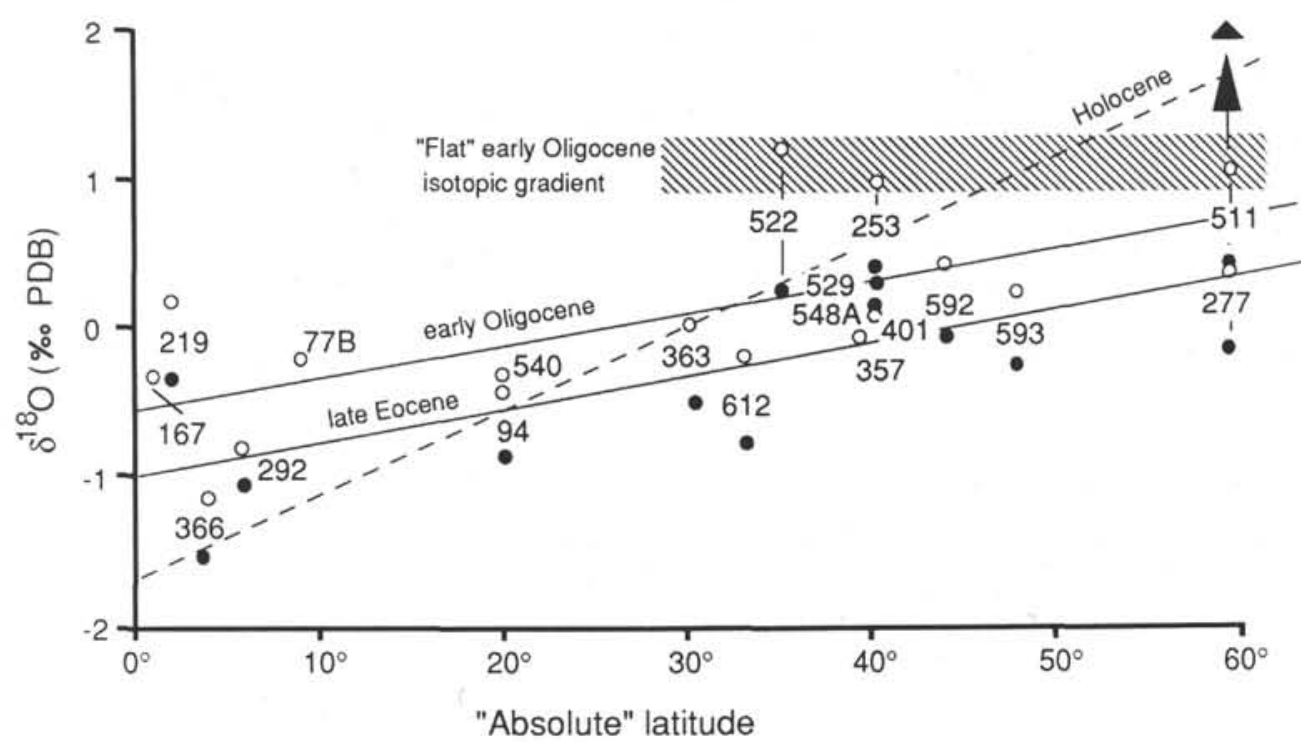

Figure 4. Average oxygen isotopic values of planktonic foraminifers of the late Eocene (solid circles) and early Oligocene (open circles) from DSDP sites plotted vs. "absolute" latitude (after Keigwin and Corliss, 1986). Regression lines are those drawn by Keigwin and Corliss (1986) to indicate isotopic gradients for the Holocene and early Oligocene. Note that the high-latitude sites ( 277 and 511$)$ have very similar values as the mid-latitude sites, producing a nearly flat isotopic gradient (highlighted by the hatched line). This would imply a flat paleotemperature gradient if no correction is considered for local salinity variations. Black triangle $=$ value for Site 511 if a correction is made for salinity of $0.9 \%$ based on present-day surface-water values at these latitudes (after Wise et al., 1991). Such a correction would yield a significantly steeper isotopic gradient for the early Oligocene.

and found for the Atlantic that during three intervals in the Oligocene, bottom-water paleotemperatures were unreasonably low (below that of the present-day oceans) if calculated on the basis of an ice-free world. They, therefore, established an ice-volume correction factor that yielded higher paleotemperatures than those derived for an ice-free world, and suggested that benthic $\delta^{18} \mathrm{O}$ values above a $1.8 \%$ (PDB) threshold indicated the presence of an ice sheet on Antarctica. They concluded that such an ice sheet must have been present during each of their three events (ca. 35, 31, and $25 \mathrm{Ma}$ ), which included the sharp positive shift during the earliest Oligocene. They noted that the ice sheet may have disappeared during portions of the Oligocene and early Miocene.

Wise et al. (1985) had reached a similar conclusion for the earliest Oligocene based on their analysis of cores from Site 511 on the Falkland Plateau, the deepest subantarctic site analyzed at that time. They noted that if an ice-volume effect were not taken into consideration, the benthic isotopic paleotemperatures for the earliest Oligocene would equal those of the present day, thereby implying a present-day temperature/circulation regime for that region. Bottom temperatures at that depth would have fluctuated between about $0^{\circ}$ and $4^{\circ} \mathrm{C}$ (paleotemperature scale "A" in Fig. 3). They reasoned that such an oceanographic regime today should produce a sedimentary record with abundant IRD, dropstones, carbonate-free sediments at comparable depths, and very low diversities of calcareous planktonic microfossils, none of which was the case for the Oligocene sediments of this plateau, which consist primarily of nannofossil diatomaceous ooze (see also Muza et al., 1983).

Wise et al. (1985) were constrained to use mixed benthic assemblages because of the scarcity of foraminifers in their sequence. Nevertheless, if the criteria suggested by Miller et al. (1987) were applied to this site, continental glacial conditions would have existed during the earliest Oligocene, and paleotemperature scale "B" in Figure 3 would be the more applicable.
However, as the ice sheet waxed and waned on the continent, the amount of correction would have to vary as well, according to the volume and nature of the ice sheet. For that reason, a sliding scale would in theory be necessary if one could constrain by independent evidence the size and nature of the ice sheet.

Although the isotopic curves for both the benthic and planktonic foraminifers would be similarly affected by icevolume effects, the planktonic curve would also be subject to a "salinity effect" if salinity values were lower in the high southern latitudes than in the lower latitudes. A linear relationship exists between salinity and the isotopic composition of the water (Epstein and Mayer, 1953; Craig and Gordon, 1965 ). A $1 \%$ salinity change causes a $0.5 \%$ change in $\delta^{18} \mathrm{O}$ of the water (Rye and Sommer, 1980; Broecker, 1989). Modern surface waters of the Atlantic and Pacific Oceans yield salinity values up to $1.8 \%$ lower in the high latitudes relative to the low latitudes (Broecker, 1989). Lower salinity values might be produced by excessive precipitation and run off from continents or by the melting of glacial ice. This would drive the surface-water readings in the negative direction, thus balancing out some of the ice-volume effect.

Poore and Matthews (1984) argued for the presence of a salinity effect in the high latitudes for the early Oligocene because they found that surface-water isotopic values at the mid-latitude Walvis Ridge Sites 522 and the subantarctic Sites 277 and 511 were essentially the same. Without a correction for salinity differences, this would imply similar paleotemperatures, but the absence of a significant temperature gradient over $20^{\circ}$ of latitude seemed quite improbable to these authors.

The isotopic gradient between these regions is also flat in the data compiled by Keigwin and Corliss (1986) for the uppermost surface dwelling planktonic foraminifers, as pointed out by Wei and Wise (1990b; see hatched line in Fig. 4). This, however, contradicts evidence for a strong lower Oligocene biological gradient between these regions. For 


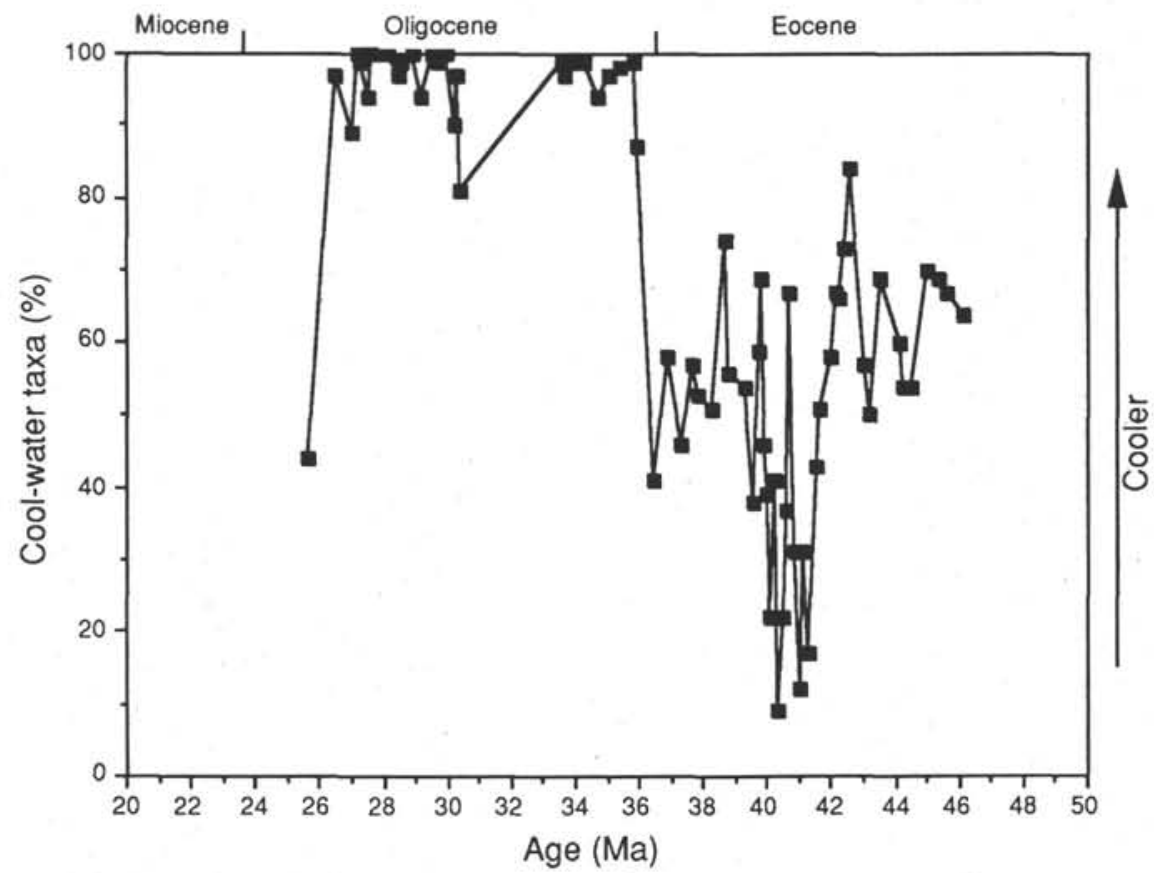

Figure 5. Changes of relative abundances of cool-water calcareous nannofossil taxa (percent of total) across the Eocene/Oligocene boundary at Site 689 in the Weddell Sea (from Wei and Wise, 1990b).

instance, Wei and Wise (1990b) showed that a steep latitudinal gradient among the calcareous nannoflora was established between the Walvis Ridge/Rio Grande Rise (about $30^{\circ} \mathrm{S}$ ) and the Falkland Plateau/Maud Rise $\left(50^{\circ}\right.$ to $\left.65^{\circ} \mathrm{S}\right)$ during the earliest Oligocene. To demonstrate this, they first plotted the percentages of cool- and warm-water nannofossil taxa at various sites along a latitudinal traverse through the South Atlantic (Fig. 5). Then they applied a polar ordination technique to compare the assemblages at each site through time (Fig. 6). Polar ordination is an axial method for putting samples in order according to their similarity values along an axis defined by two end member samples (see Cisne and Rabe, 1978, for a detailed description of the method). Next, Wei and Wise (1990b) established the degree of similarity of the nannoflora of the different sites in relation to Site 689 for 3 time intervals to illustrate the dramatic shift that occurred at the earliest Oligocene (Fig. 7). In Figure 7, the similarity is expressed as correlation coefficients. Wei and Wise (1990b) then scaled their biological gradient against low-latitude isotopic paleotemperature curves corrected for ice volume in order to derive the isotherms shown in Figures $8 \mathrm{~A}$ and $8 \mathrm{~B}$ for the late Eocene and early Oligocene respectively. This yielded lower Oligocene surface-water values at the Falkland Plateau (Site 511) and Maud Rise (Site 689) of about $7^{\circ}$ and $3^{\circ} \mathrm{C}$, respectively; paleotemperatures along the margins of Antarctica close to $0^{\circ} \mathrm{C}$ would seem feasible.

The above approach appears to be valid in that the order of the sites along the nannofossil biological gradients for each time slice indicated in Figure 7 is the same as for their geographic positions along latitude. This would not always be the case if the sites were ordered according to their isotopic values. As noted by Wei and Wise (1990b), the average $\delta^{18} \mathrm{O}$ value of the early Oligocene planktonic foraminifers (Globigerina ampliapertura) from Site 516 is about $-0.7 \%$ (Williams et al., 1985), whereas at the lower latitude Site 522 (Poore and Matthews, 1984), it is about $0.7 \%$. This would suggest surface-water temperatures up to $6^{\circ} \mathrm{C}$ warmer at Site 516 than at the lower latitude Site 522. The quantitative nannofossil data, however, indicate that the nannoflora at Sites 516 and 522 have similar temperature characteristics, but that the surface waters at the higher latitude Site 516 were slightly cooler.

Wei and Wise (1990b) argued that it was quite likely that precipitation exceeded evaporation during the Oligocene in the high latitudes, as suggested by evidence for rain forests in those regions (Kemp, 1978). A salinity effect might also explain the fact that the $\delta^{18} \mathrm{O}$ values of Devereux (1967) from New Zealand are over 1\%o lower than those reported from the nearby open ocean drill sites on the Campbell Plateau and Macquarie Ridge by Shackleton and Kennett (1975). Assuming a correction for salinity of $0.9 \%$ in $\delta^{18} \mathrm{O}$ (about half that for present-day surface-water values at these latitudes), the paleotemperature curve in Figure 3 (or for any other high latitude site) could be rescaled, thus arriving at the bottom scale ("C") in Figure 3. This scale indicates an average surface-water paleotemperature of about $7^{\circ} \mathrm{C}$ for the early Oligocene at Site 511 , which agrees with that derived from the biogeographic gradient for the calcareous nannofossils (Fig. 8). Previously, Wise et al. (1991) used a salinity correction of $1.3 \%$, which we now consider excessive. Alternative explanations can be postulated to account for the flat isotopic gradient depicted in Figure 4. The burial depth of the lowermost Oligocene at Site 516 is in excess of 500 mbsf (Barker, Carlson, Johnson, et al., 1983), thus diagenesis may be a factor. On the other hand, excessive evaporation in the mid latitudes could have increased the $\delta^{18} \mathrm{O}$ values there. Model simulations by Barron and Peterson (1991) show surface salinity values of $37.5 \%$ extending out from the Southwest African coast and over Site 522 from the Paleocene through the Miocene. This, combined with excessive precipitation in the high latitudes, could have produced the flat isotopic gradient noted in Figure 4.

Ironically, Shackleton and Kennett (1975), using no corrections for either ice volume or surface-water salinity values, derived surface-water paleotemperatures similar to those of Wei and Wise (1990b) for the subantarctic region and the margin of 


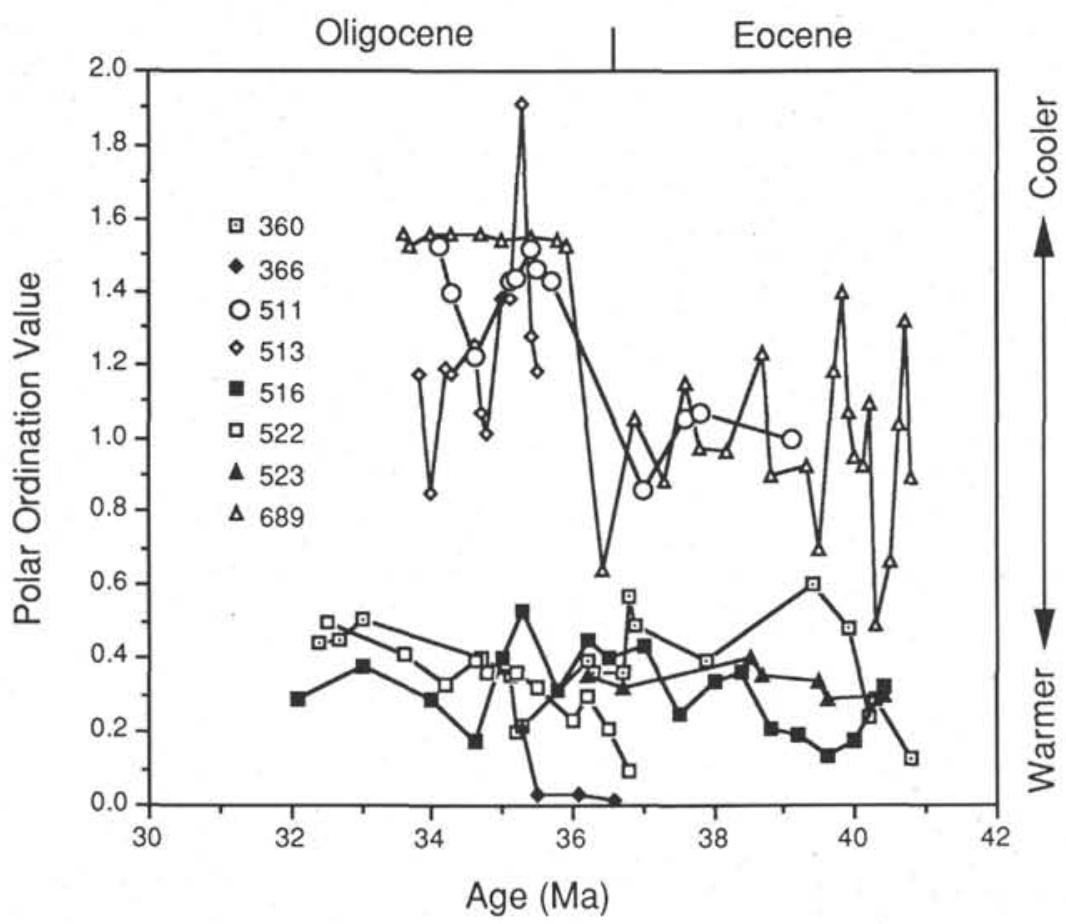

Figure 6. Changes in nannofossil assemblage characteristics across the Eocene/ Oligocene boundary expressed by polar ordination values for assemblages at sites along a latitudinal transect through the South Atlantic. The higher the values, the cooler the inferred surface-water temperatures (after Wei and Wise, 1990b). See Figure $8 \mathrm{~A}$ for the locations of these sites.

Antarctica. This is apparently because the ice-volume and salinity effects virtually canceled each other out at their subantarctic locality. Shackleton and Kennett (1975), however, concluded from their analysis that sea ice could have been present during the early Oligocene but not an ice sheet.

In Figure 4, regression lines were drawn for the Eocene and Oligocene DSDP data by Keigwin and Corliss (1986), which indicate much lower isotopic gradients than for the Holocene. In addition, the slopes for the Eocene and Oligocene regression lines are the same, indicating similar gradients across latitude. The salinity correction suggested above, plus additional data compiled by Zachos et al. (this volume; see discussions to follow) for more recently drilled ODP high-latitude sites in the Weddell Sea and on the Kerguelen Plateau, however, indicate that the earliest Oligocene gradient was considerably steeper relative to that suggested by Keigwin and Corliss (1986), more similar to that of the present day, as suggested by the biological data outlined above. On this basis, Zachos et al. (this volume) think that an ice sheet could have been supported by the implied sea-surface temperatures.

The above examples illustrate, however, how difficult it is to assess the presence/absence and probable nature of Antarctic ice using stable isotopes alone. Many assumptions that cannot be easily verified by independent evidence need to be made. Investigators agree that more direct evidence of early Oligocene glaciation must be obtained if the fundamental questions on Paleogene glaciation posed previously are to be answered. As a result of the recent exploration efforts, additional evidence is beginning to accumulate.

On the continent, a most unusual line of evidence was developed with the discovery of reworked Cenozoic microfossils, mainly diatoms, in upper Neogene tills of the Sirius Group, a series of glacial deposits in the Transantarctic Mountains (McKelvey et al., 1987, 1991). Recycled diatom fragments were first discovered in the field in 1978 by H. T. Brady, who thought they were contaminants from snow he melted to make the microfossil preparations $(\mathrm{H}$. T. Brady, pers. comm. to $\mathrm{DMH}, 1988)$. Four years later, diatoms in these tills were rediscovered by Harwood (1983), who recognized their possible significance. Webb et al. (1983, 1984, and references therein) then recovered rich Pliocene, Miocene, Oligocene, and Eocene siliceous and calcareous microfossil assemblages in over a third of the Sirius Group samples examined from a variety of locations (Fig. 9). They suggested that the microfossils had been eroded from intracratonic marine basins now buried beneath the East Antarctic ice sheet. The presence of the recycled fossils would indicate that the basins were ice-free or emergent at some times, and their absence might imply times when the basins were occupied by ice. On this basis, Webb et al. (1984) and Harwood et al. (in press; see additional references therein) concluded that an ice sheet may have been present over East Antarctica during the latest Eocene-earliest Oligocene (Fig. 10). ${ }^{7}$

\footnotetext{
${ }^{7}$ Investigators also discovered finger-size pieces of fossil wood and numerous leaf impressions of Nothofagus in tills of the Sirius Group of the Transantarctic Mountains and dated them as Pliocene (Webb and Harwood, 1987; Peterson, 1991; Harwood et al., in press). As a result, Webb and his colleagues postulated a series of major deglaciations of the Antarctic ice sheets during Oligocene to mid-Pliocene times. They considered these ice sheets to have been "temperate" in nature and suggested that Pliocene deglaciations, which may have destroyed much of the ice sheet, occurred as late as 3.4 to $2.8 \mathrm{Ma}$ (Harwood, 1985; Webb et al., 1984; Webb and Harwood, 1987; Harwood et al., in press; D. M. Harwood and P.-N. Webb, unpubl. data, 1990; Barrett, in press; see also Breza, this volume, and Dowsett and Cronin, 1990). After that, a colder, "polar" ice sheet formed, which has existed to the present day. The notion of a strong deglacial event during the mid-Pliocene has been strongly disputed by Prentice and Matthews (1988), Kennett and Barker (1990), and Denton et al. (in press). Kennett and Barker (1990; see also Barker, Kennett, et al., 1988, and Barker et al., 1988) contended that the Leg 113 drilling results show no such event.
} 


\begin{tabular}{r|rr} 
Oligocene & \multicolumn{2}{c}{ Eocene } \\
\hline $30.0-36.5 \mathrm{Ma}$ & $36.6-40.9 \mathrm{Ma}$ & $41.0-45.9 \mathrm{Ma}$
\end{tabular}

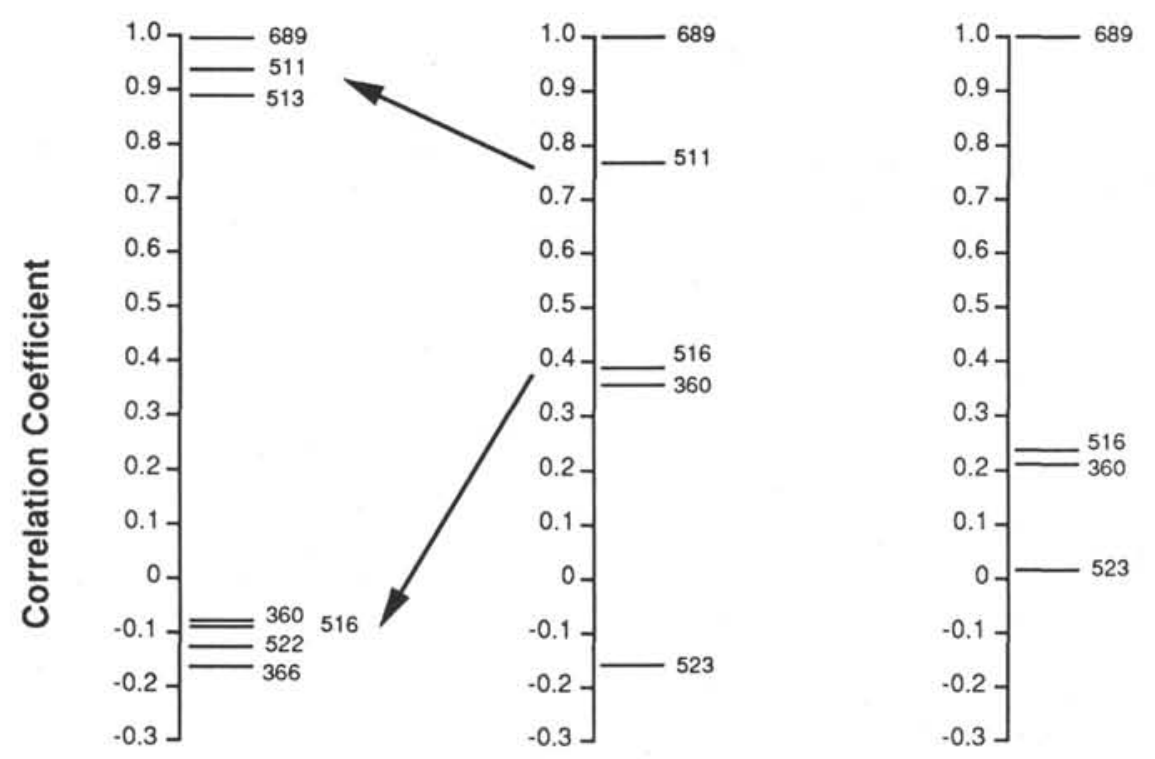

Figure 7. Changes in nannofossil assemblage characteristics across the Eocene/Oligocene boundary expressed by correlation coefficients of the nannoflora for the sites in Figure 6 in relation to southernmost Site 689 (after Wei and Wise, 1990b).
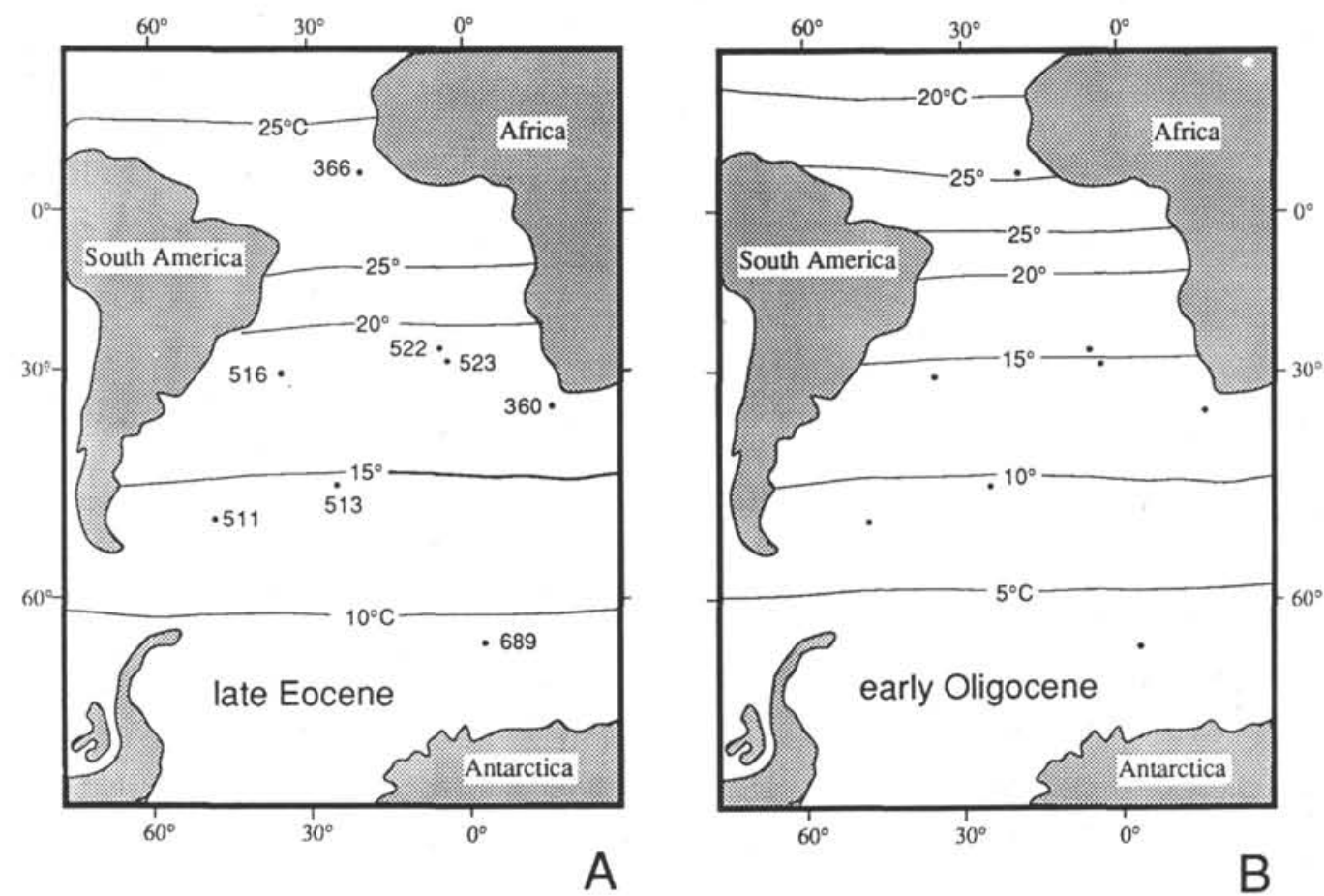

Figure 8. Estimated surface temperatures of the South Atlantic Ocean during the late Eocene (A) and early Oligocene (B) based on oxygen isotopic data and latitudinal biogeographic gradient data. For simplicity, possible inflections of the isotherms caused by circulation patterns are not shown. 


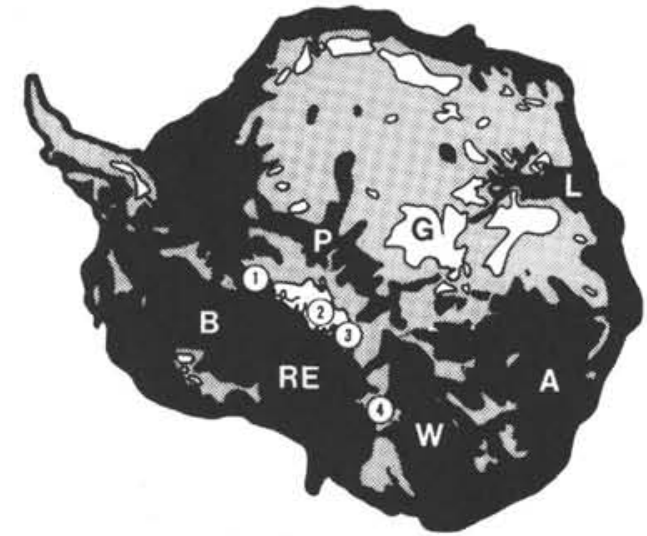

PRESENT SUBGLACIAL GEOGRAPHY

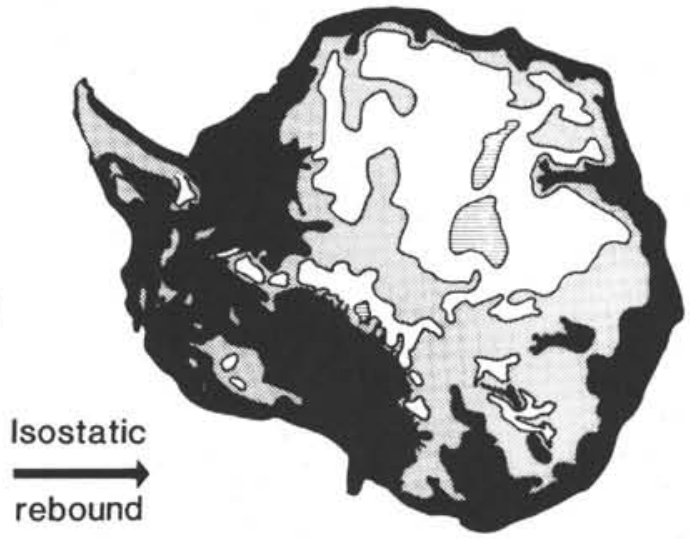

DEGLACIAL ADJUSTED GEOGRAPHY

Figure 9. Maps showing the present and isostatically adjusted geography of subglacial Antarctica (after Drewry, 1983). Black represents depth from $1000 \mathrm{~m}$ below sea level to sea level. Stippling represents elevations from 0 to $1000 \mathrm{~m}$; other contours at $1000-\mathrm{m}$ intervals. Numbered sites in the Transantarctic Mountains identify Sirius Group localities as follows: 1 = Reedy Glacier area; $2=$ Beardmore Glacier area; $3=$ Mt. Sirius area, and $4=$ Dry Valley area. White letters refer to subglacial basins that experienced repeated marine incursions during times of decreased ice volume and elevated sea level. B = Byrd Subglacial Basin, RE = Ross Embayment, P = Pensacola Basin, W = Wilkes Basin, A $=$ Aurora Basin, and $\mathrm{L}=$ Lambert/Amery Basin. The black letter " $\mathrm{G}$ " denotes the Gamburtzev Mountains.

To the north of the Weddell Sea, near the tip of the Antarctic Peninsula, Birkenmajer and Gazdzicki (1986) and Birkenmajer et al. (1986) obtained a K-Ar radiometric date more than $26.6 \mathrm{Ma}$ (probably ca. 29.5 Ma) on andesitic-dacitic lavas that overlie Paleogene glaciomarine sediments and till thought to be Oligocene in age (Birkenmajer et al., 1988; Gazdzicki, 1989). Aside from the minimum age provided by the radiometric date, however, the age of the tillite is derived from calcareous nannofossils and foraminifers within the sequence. The till represents the "Polenz Glaciation," which according to Birkenmajer et al. $(1988$, p. 9) is the most extensive of the several Cenozoic cryospheric events recorded in Antarctica.

The Oligocene age attributed to the assemblage mentioned above cannot be confirmed. All of the specimens well illustrated by SEM appear to have been reworked from the Eocene. This includes a chalk-encrusted foraminifer that has been illustrated in a number of publications with various interpretations as to age (cf. Gazdzicka and Gazdzicki, 1985; Birkenmajer and Gazdzicki, 1986; and Gazdzicki, 1989); a middle Eocene age appears to be most likely for the specimen based on the presence of the nannofossil Chiasmolithus gigas (Wise, 1988). Gazdzicka and Gazdzicki (1985) report from the assemblage, but do not illustrate, a specimen of Coronocyclus nitescens (Kamptner), which Birkenmajer et al. (1988) used to place a maximum age of ca. 31-32 Ma (late early Oligocene) on the glacial deposits in question. Virtually identical forms, however, have been described from the Eocene by Hay et al. (1966) as Coronocyclus serratus, which some consider to be a junior synonym of $C$. nitescens (Perch-Nielsen, 1985). Other specimens from neptunian dikes through the glacial unit in question are said to contain specimens of the Oligocene(?)-Pliocene Sphenolithus abies. The specimen illustrated (Birkenmajer et al., 1988 , plate 1, fig. 14), however, is poorly preserved, displays no apical spine, and cannot be identified as $S$. abies, which most specialists consider to be middle Miocene to middle Pliocene in age (Perch-Nielsen, 1985).

With the resumption of Antarctic deep-sea drilling in 1987 after an 8-yr hiatus, ODP Leg 113 drilled Site 693 on the East Antarctic margin in the Weddell Sea (Fig. 1). There, a 47-m-thick sequence of Oligocene diatomaceous muds (Fig. 11) containing ice-rafted sands and dropstones (Fig. 12) was dated at $33 \mathrm{Ma}$ (early Oligocene). These deposits along the continental slope (present-day water depth $=2359 \mathrm{~m}$ ) provided the first unequivocal evidence of Paleogene ice-rafting beyond the inland seas and shelves of Antarctica (Leg 113 Shipboard Scientific Party, 1987). The base of this sequence is separated by a disconformity from mid-Cretaceous sediments below (Barker, Kennett, et al., 1988). Erosion, possibly induced by the onset of glacial activity at sea level in the Weddell Sea, erased any sedimentary record of the sharp earliest Oligocene climatic event recorded elsewhere in the isotopic record. Offshore on Maud Rise, where a complete latest Eocene-early Oligocene transition was recorded in carbonate sediments at Site 689, no IRD was detected in the lowermost Oligocene (Barker, Kennett, et al., 1988, 1990). Nevertheless, Wise et al. (1987) interpreted the ice-rafted debris at Site 693 as evidence of the presence of an early Oligocene East Antarctic ice sheet. Kennett and Barker (1990), however, did not consider the evidence gathered during Leg 113 strong enough to postulate the existence of such an ice sheet. They judged the amount of lower Oligocene IRD to be minor relative to that in the Neogene, although the amount of gravel recorded by Grobe et al. (1990, figs. 2 and 3) in those cores is comparable with that in most Neogene samples, except for higher amounts in the latest Miocene. The amount of IRD noted in the lower Oligocene by Grobe et al. (1990), however, appears to have been understated as a result 

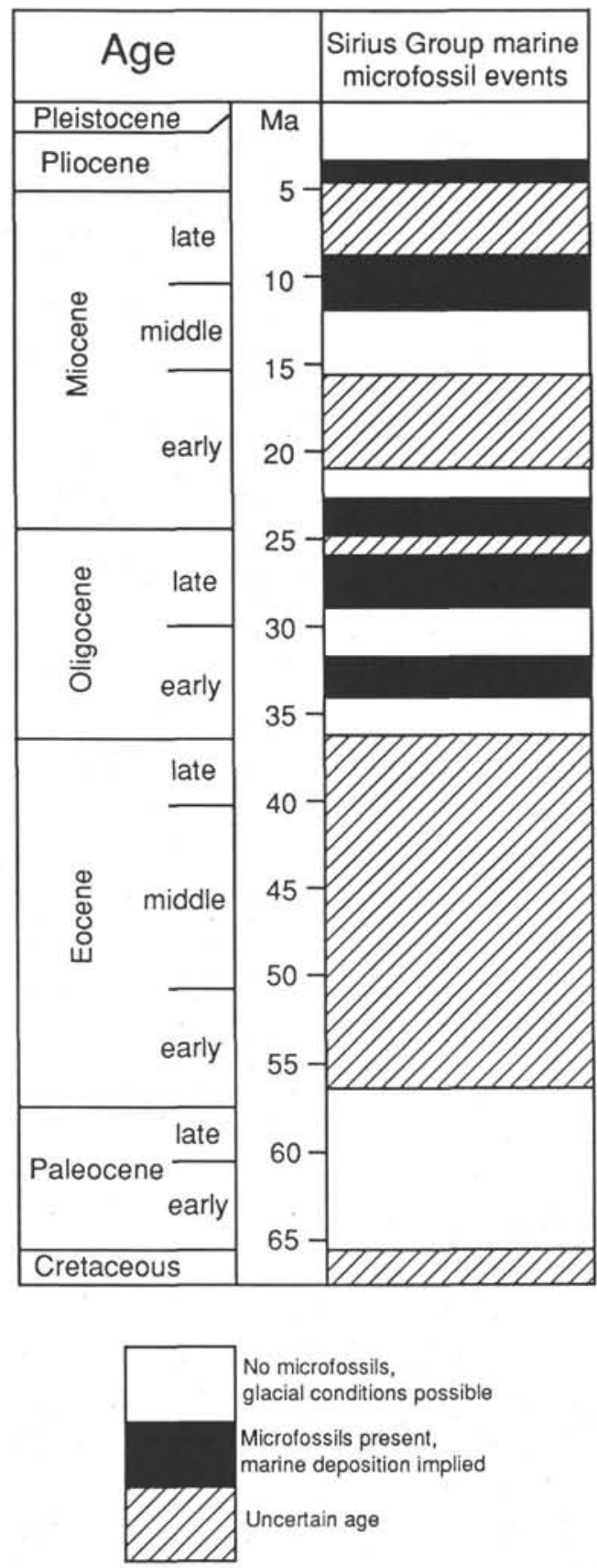

Figure 10. Episodes of marine deposition in the Wilkes-Pensacola basins as indicated by the presence of diatoms and other marine microfossils reworked into the Sirius Group tills (see Fig. 9) (after Harwood, 1983; Harwood et al., in press). For the post-Paleocene interval, the absence of such fossils could indicate times that these basins were occupied by an ice cover.

of their sample spacing. For instance, they report in their text no gravel in Core 113-693B-18X, although significant amounts of IRD and dropstones are evident in the two photographs of that core (Figs. 12A and B).

A predominance of illite in the clay fractions of the Oligocene cores at Site 693 attests to a dominance of physical weathering processes onshore (Grobe et al., 1990; Robert and Maillot, 1990). Through their clay mineral analyses, Robert and Maillot (1990) showed that a major change from chemical to physical weathering processes occurred on East Antarctica at some time around the Eocene/Oligocene boundary, indicating the onset of a colder climate. This resulted in a change from smectite- to illite-dominated clay mineral assemblages at Maud Rise Sites 689 and 690, 700 km northeast of Site 693 (Fig. 1). Thin beds of nannofossil ooze in the upper Oligocene at Site 693, however, indicate brief intervals of climate amelioration on East Antarctica during that epoch (Wei and Wise, 1990b).

Meanwhile, two holes drilled on the Antarctic continental shelf in the Ross Sea area by a New Zealand team recovered upper Oligocene to lower Miocene glacial sediments in the MSSTS-1 drill core (Barrett, 1986; Barrett et al., 1987a) and glacial marine sediments as old as $36 \mathrm{Ma}$ (earliest Oligocene) at the nearby CIROS-1 drill site (Barrett et al., 1989; see also Wei, this volume, Chapter 64). Harwood et al. (1989a) reviewed criteria for dating the CIROS- 1 drill core and revised previous ages for the base of the MSSTS-1 core. The 702-mlong CIROS-1 core hole provided the most complete Paleogene glacial record to date and the only one for which an attempt has been made to correlate glacial pulses with eustatic sea-level drops (Fig. 13).

The drill rig at the CIROS-1 site was located on present-day ephemeral sea ice, but the presence of lodgment tills at this location indicated that the ice front extended at times during the Oligocene well beyond that of the present day. Deep-water mudstone units, interbedded with the glacial tills, suggest that when ice sheets were present, there was wide variation in ice margin position and ice volume. The initial interpretation of the sequence suggested that the early Oligocene ice stemmed from valley glaciers along the Transantarctic Mountains that reached sea level, and that this alpine glaciation was followed in the late Oligocene by the full-scale development of several ice sheets in East Antarctica that advanced repeatedly over the drill site (Barrett et al., 1987b, 1991). Variations in water depth and glacial extent indicate considerable changes in the ice sheet during the Oligocene (Fig. 13), which are not reflected in the deep-sea isotope records (left portion of Fig. 13). There is a considerable difference between the ice volume estimates rendered by the isotope studies of Miller et al. (1987) and Prentice and Matthews (1988); the latter estimate an Oligocene ice volume as much as twice that of the present day. From their interpretation of the physical record of the CIROS-1 core, Barrett et al. (1989) suggested an ice volume intermediate between the estimates based on the two isotope studies. They also correlated the intensification of cryospheric activity during the mid-Oligocene with the major Oligocene sea-level drop, now dated by Haq et al. (1987) at $30 \mathrm{Ma}$ (Fig. 13).

Pollen and a fossil leaf recovered in CIROS-1 (Mildenhall, 1989; Hill, 1989; see also Barrett et al., 1989) identify a "cool to cold temperature" terrestrial climate on the flanks of the adjacent transantarctic mountains, where coastal enclaves of vegetation persisted through repeated phases of glacial advances in the late Oligocene. Harwood et al. (in press) think that the "temperate" character and repeated growth/decay of continental-scale glaciations recorded in CIROS- 1 provide a good analog for subsequent pre-Pleistocene glacial-deglacial variations. Their example from the CIROS-1 core demonstrates how physical evidence from the Antarctic continent itself can be critical in constraining and rendering more accurate interpretations of the distal proxy (i.e., deep-sea) records.

Further drilling by the JOIDES Resolution in Prydz Bay, Antarctica (Fig. 1) by Leg 119 (Leg 119 Shipboard Scientific Party, 1988; Barron, Larsen, et al., 1989, 1991) penetrated over $100 \mathrm{~m}$ of lower Oligocene diamictites interpreted as lodgment tills and glaciomarine sediments deposited at and 
Site 693

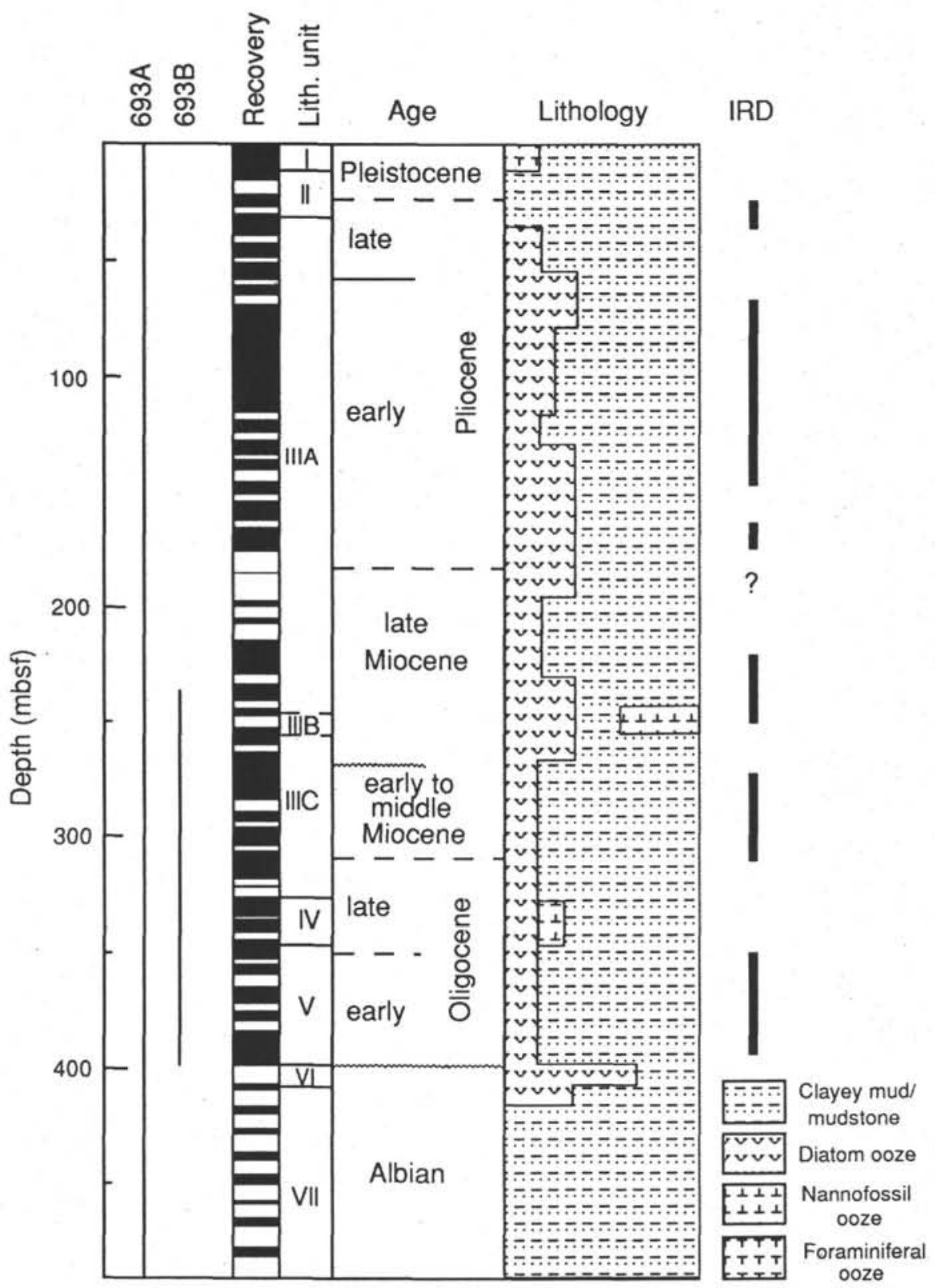

Figure 11. Stratigraphy for two holes at Site 693 on the continental slope of the Weddell Sea off the margin of East Antarctica showing the interval with appreciable ice-rafted debris (IRD) in the lower Oligocene and nannofossil ooze in the upper Oligocene (Barker et al., 1988). IRD occurrences from Grobe et al. (1990); black indicates recovered intervals (from Wise et al., 1991).

below sea level (Fig. 14). Below these sediments are more diamictites, which magnetostratigraphy indicated could be late Eocene to latest middle Eocene in age. The areal extent (as shown by seismic stratigraphy) and overcompacted nature of these sediments indicate that grounded ice in the past extended at least $140 \mathrm{~km}$ beyond the limits of the present-day ice shelf. This convinced the Leg 119 scientists that full-scale ice-sheet development had taken place over East Antarctica by early Oligocene time or possibly earlier (Leg 119 Shipboard Scientific Party, 1988; Barron et al., 1991a). In addition to the above, Leg 119 encountered lower Oligocene quartz sands and granules at Sites 738 and 744 on the southern Kerguelen Plateau (Fig. 1), some or all of which they speculated could have been ice-rafted from East Antarctica, West Antarctica or from islands on the plateau itself (Barron, Larsen, et al., 1989). The presence of lower Oligocene IRD in these cores has been confirmed by Ehrmann (1991) as well as by our own studies of the material.

During cruise Leg 120 to the Central Kerguelen Plateau, lower Oligocene IRD was recovered at Site 748 at a shallowwater depth $(1250 \mathrm{~m})$ and at $58^{\circ} 26.45^{\prime} \mathrm{S}$ latitude (Leg 120 Scientific Party, 1988; Fig. 1). The physiologic and tectonic 
A

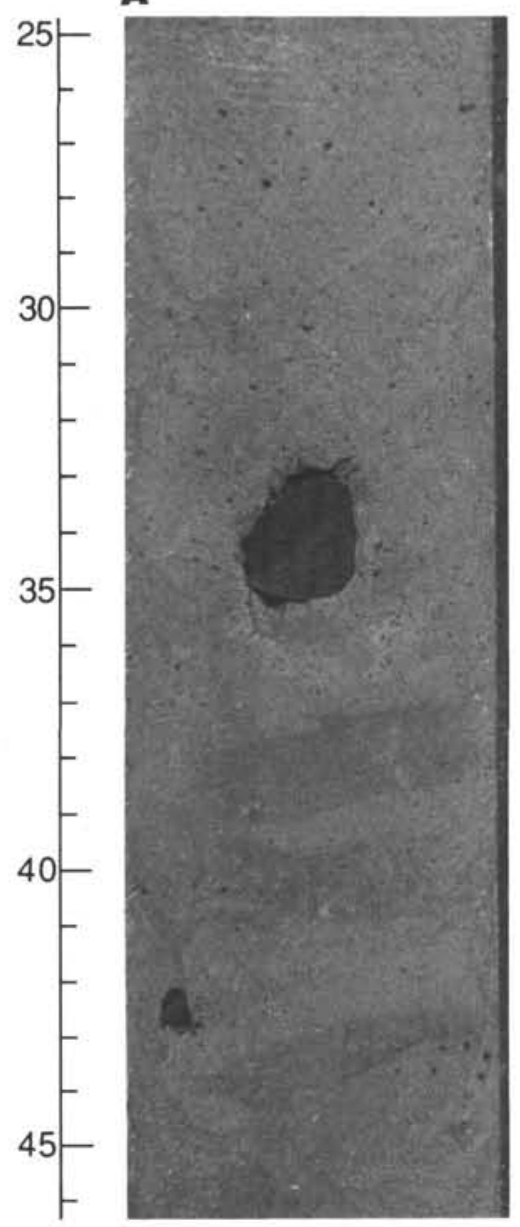

B

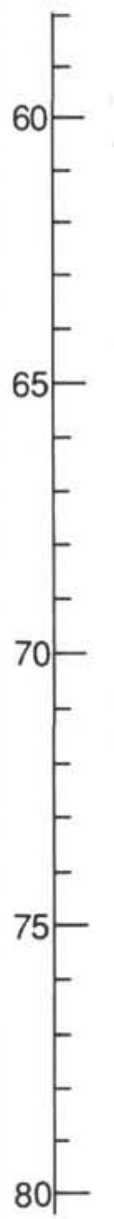

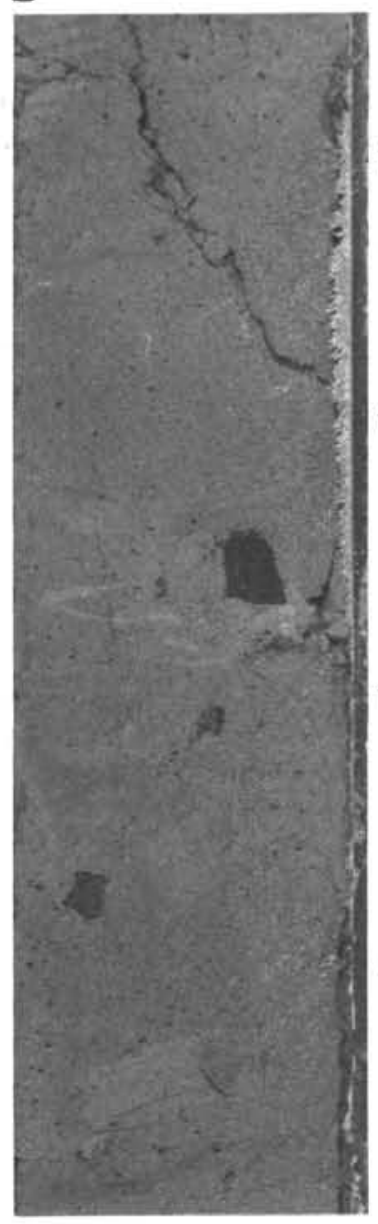

C

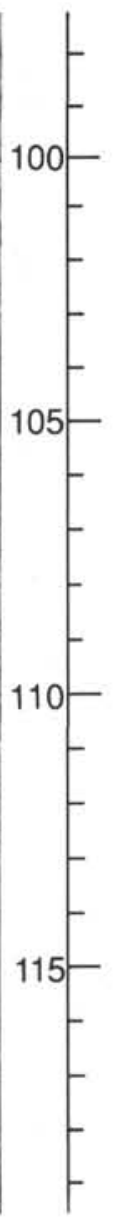

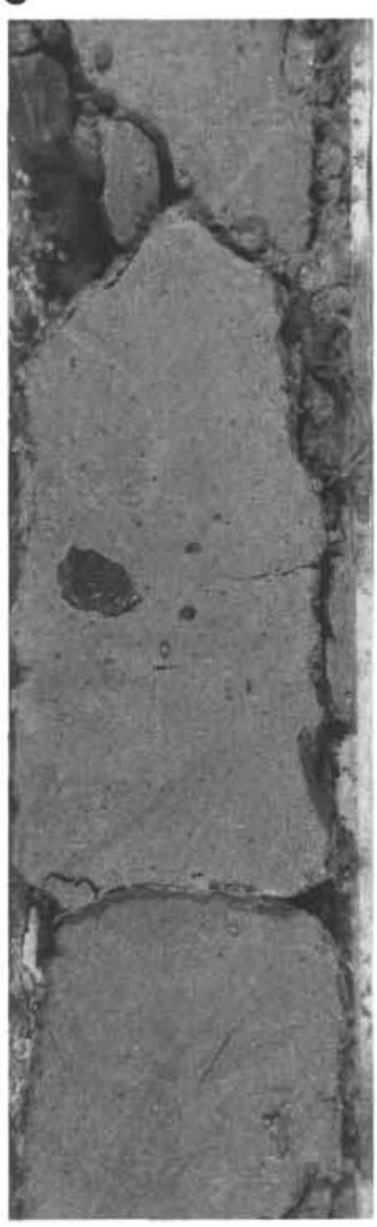

Figure 12. Ice-rafted debris from the lower Oligocene cores of Site 693, Weddell Sea (photographs courtesy of S. O'Connell). A. Section 113-693B-18X-1, 24.5-46.5 cm. B. Section 113-693B-18X-2, 58-80.5 cm. C. Core 113-693B$15 \mathrm{X}-1,97-119.5 \mathrm{~cm}$.

setting of the site and the coarse size of the material ruled out transport of the clastic materials by turbidity currents, nepheloid layers, or wind. The IRD is contained within a stratum of biosiliceous nannofossil ooze (Fig. 15) and is composed of predominately fine to coarse sand-sized material consisting of quartz, altered feldspars, and minor amounts of mica and heavy minerals (Breza and Wise, this volume). A large portion of the quartz grains are highly angular with fresh conchoidal fractures and other surface textures that, according to Krinsley and Donahue (1968), are characteristic of glacially derived material (Figs. 16A-16C). Scanning electron microscope, energy dispersive X-ray, and petrographic studies also confirm the presence of a heavy mineral suite characteristic of metamorphic or plutonic source rocks (e.g., Fig. 16D), indicating ice-rafting from East Antarctica rather than from local sources on the Kerguelen Plateau (a volcanic edifice) or from the devitrification of volcanic ash (Breza et al., 1988; Breza and Wise, this volume).

The IRD at Site 748 is earliest Oligocene in age (35.8-36 $\mathrm{Ma}$; see Appendix). It coincides with a dramatic increase in the percentage of cold-water calcareous nannofossils (Fig. 17, from Wei et al., this volume), as well as a complementary increase in $\delta^{18} \mathrm{O}$ values of surface-dwelling planktonic foraminiferal of $0.6 \%$, and of $1.0 \%$ in intermediate depth forms. The sharp positive shift in benthic foraminiferal values seen at other sites around the globe is recorded as a $1.2 \%$ increase here, and benthic foraminiferal $\delta^{13} \mathrm{C}$ values increase by $0.9 \%$ (Figs. 18 and 19, from Zachos, et al., this volume). The percent calcium carbonate in the sediment drops from $\sim 95 \%$ to $\sim 75 \%$ at the same point in the core (Fig. 18).

A similar coincidence of lower Oligocene IRD with an increase in stable isotope values and biosiliceous material and a decrease in $\mathrm{CaCO}_{3}$ plus a change in clay mineral assemblages was reported at Leg 119 Sites 738 and 744 to the south $\left(63^{\circ}\right.$ and $62^{\circ} \mathrm{S}$ latitude, respectively) (Barron et al., 1991a; Ehrmann, 1991; Barrera and Huber, 1991). The IRD at Site 738 , however, is about $1 \mathrm{~m} . \mathrm{y}$. younger than that at the other two Southern Kerguelen Plateau sites (see Appendix for age models of these occurrences).

As noted previously, the occurrence of lower Oligocene IRD at Site 748 some $1000 \mathrm{~km}$ north of the Antarctic continent (the lowest latitudinal occurrence known for the early Oligocene) and its coincidence with the sharp $\delta^{18} \mathrm{O}$ shift led Breza et al: (1988), Zachos et al. (1989), Breza and Wise (this volume), and Zachos et al. (this volume) to postulate the existence of an earliest Oligocene ice sheet on the Antarctic continent.

The stratigraphic occurrences of reported Paleogene glacial and glaciomarine sediments are compared in Figure 20. Some of the stable isotope records on which interpretations of cryospheric development have been made are reproduced in Figures $2,3,13,18,19$, and 20 (right). Some of the evidence 


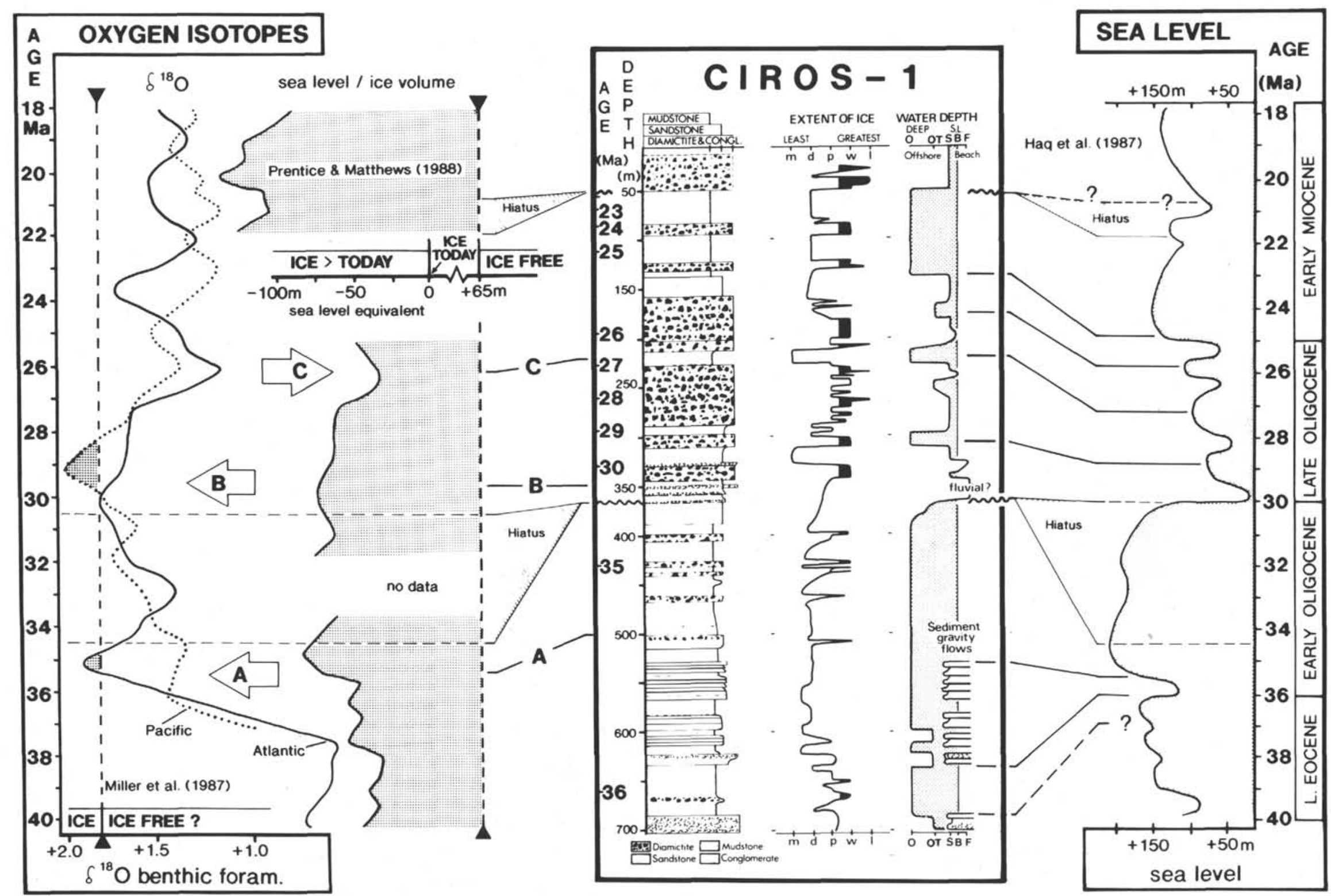

Figure 13. Stratigraphy of the CIROS-1 drill core from the Ross Sea showing inferred variation in ice extent and water depth (center) and correlations with the sea level curve of Haq et (1987), the smothed oxygen isotope curves for benthic foraminifers from the Atlantic and Pacific of Miller et al. (1987), and an ice-volume curve based on the difference between benthic and planktonic oxygen isotope data from Prentice and Matthews (1988). Figure is from Barrett et al. (1989), who note that in comparison with their interpretation of the physical record 
Ingrid

Christensen

Prydz Bay

Shelf

Coast
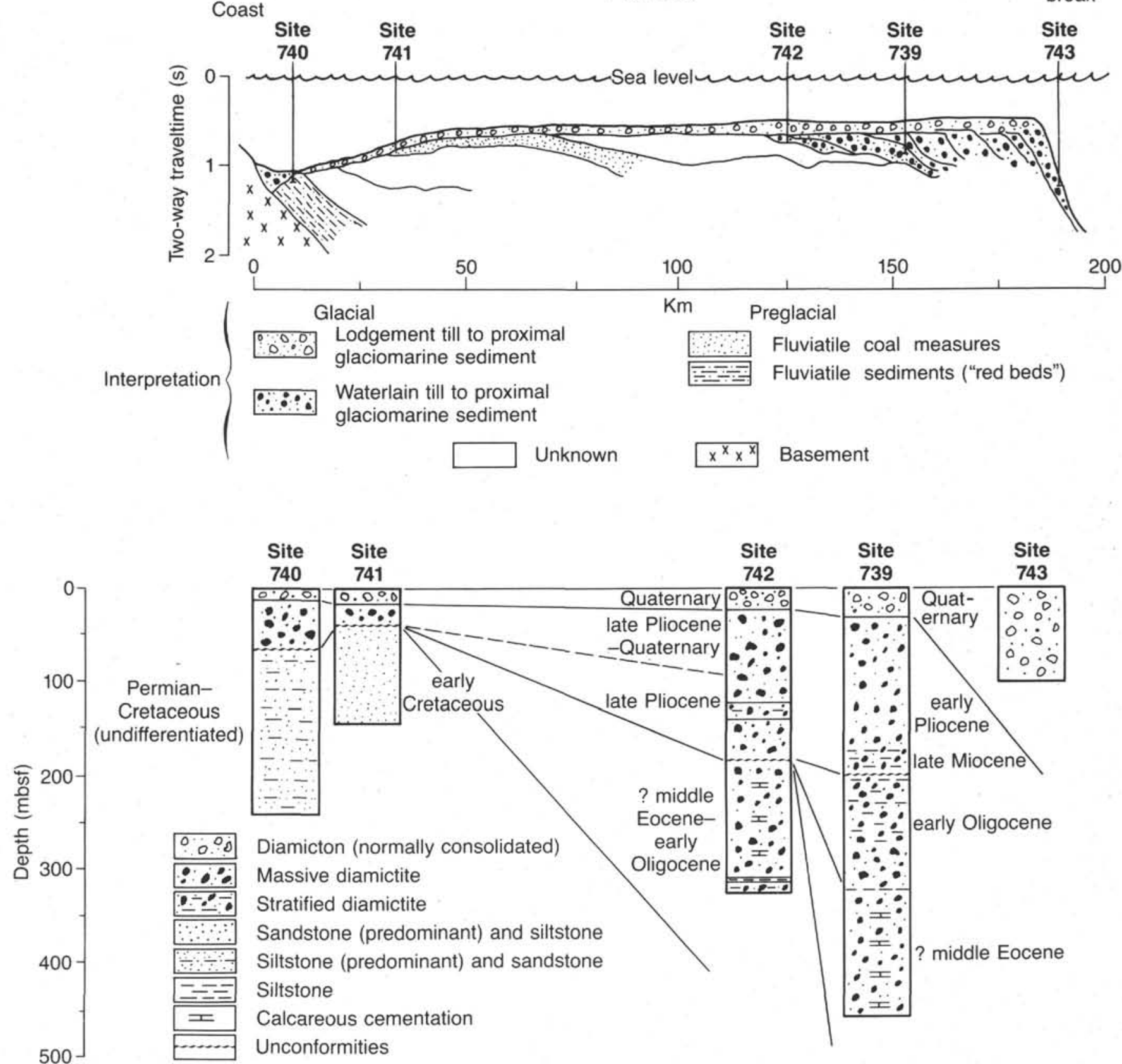

Figure 14. Sediment facies recovered by Leg 119 drilling in Prydz Bay showing presence of massive, glaciomarine diamictites in lower Oligocene and possibly older sequences (from Leg 119 Shipboard Scientific Party, 1988).

is highly interpretative, and in some instances the same evidence has been cited to support both sides of the issue. We can summarize the main arguments that can be made in favor of the existence of an early Oligocene ice sheet(s) on Antarctica as follows:

1. The benthic and/or planktonic foraminiferal stable isotope records reflect evidence of an ice-volume effect; therefore an ice sheet must have been in existence (Matthews and Poore, 1980; Miller and Fairbanks, 1983; Keigwin and Keller, 1984; Hsü et al., 1984; Shackleton et al., 1984; Wise et al.,
1985; Miller and Thomas, 1985; Keigwin and Corliss, 1986; Shackleton, 1986; Zachos et al., this volume). If the planktonic foraminifers did not show a significant ice-volume effect, tropical and mid latitude sea surface paleotemperatures would be unacceptably low (Poore and Matthews, 1984).

2. The sharp positive stable isotope shift is the most profound of the Cenozoic and is correlated with the development of the psychrosphere (Shackleton and Kennett, 1975) and with ice-rafting well beyond the margins of the Antarctic continent at Site 748 (Breza et al., 1988; Zachos et al., 1989; Breza and Wise, this volume; Zachos et al., this volume), all 

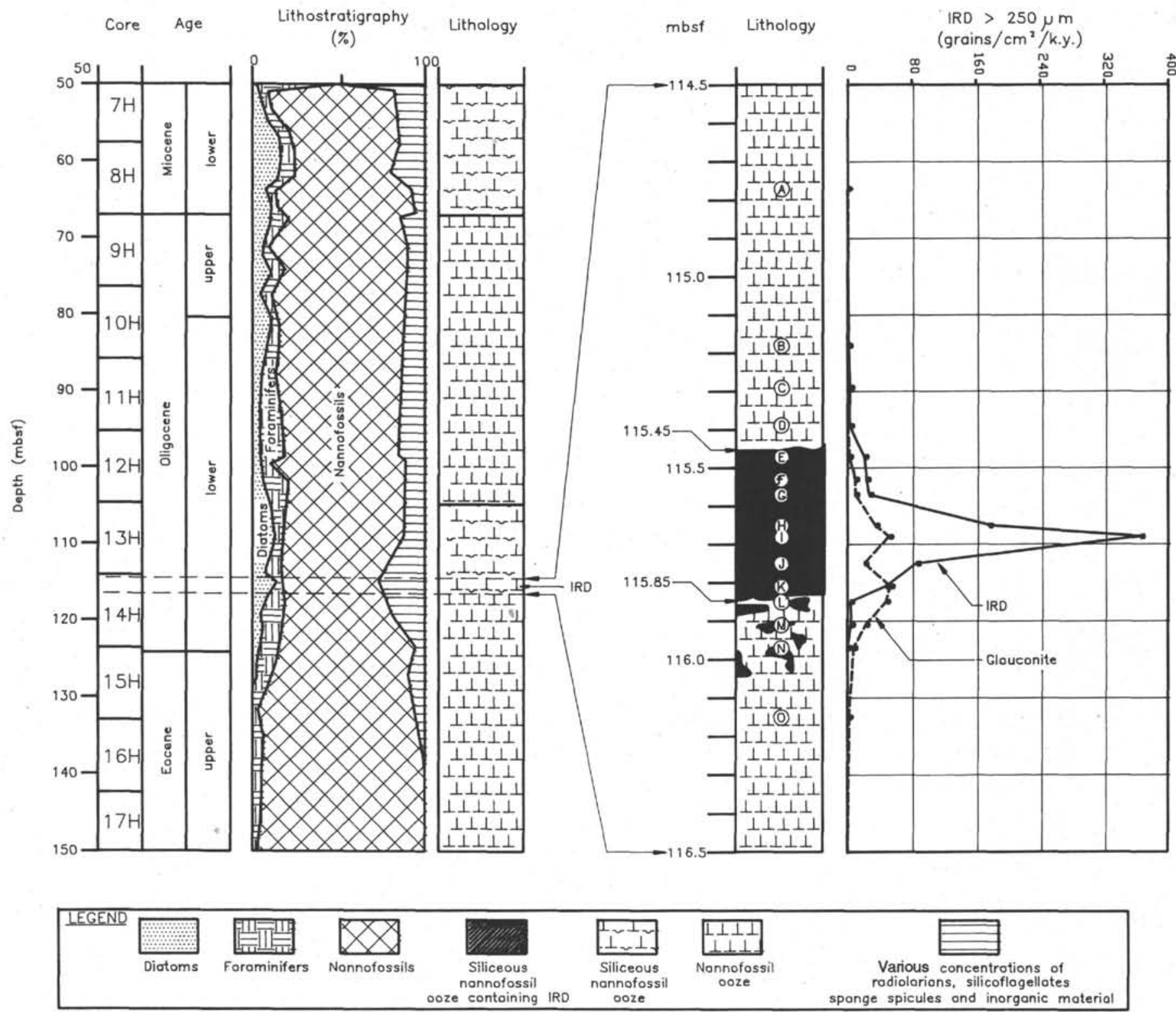

Figure 15. Occurrence of lower Oligocene ice-rafted debris (IRD) in a siliceous nannofossil ooze in Hole 748B on the Kerguelen Plateau, 1000 $\mathrm{km}$ north of East Antarctica, which was the source for the material. Lithology and sediment components determined from smear slide analysis. The graph shows the vertical extent of the ice-rafted event and its apparent accumulation rate (from Breza and Wise, this volume). Letters " $A$ " through " $O$ " refer to intervals of the samples analyzed for IRD.

of which suggests a major cryospheric event. A similar correlation can be made at Sites 738 and 744 (Barron et al., 1991a).

3. Paleontologic data show a significant cooling and a steepening of latitudinal gradients during the earliest Oligocene that resulted in the reorganization of planktonic biogeographic provinces (Haq et al., 1977, 1979; Kennett, 1978; Sancetta, 1979; Wei and Wise, 1990b, in press; Wei et al., this volume).

4. Glaciomarine sediments have been discovered at three widely spaced localities around Antarctica (Weddell Sea, Ross Sea, and Prydz Bay). Such widespread glaciation must be supported by an ice sheet (Leg 119 Shipboard Scientific Party, 1988; Wise et al., 1991).

5 . IRD has been detected as much as $1000 \mathrm{~km}$ beyond the Antarctic margin; the source is most likely East Antarctica
(Breza et al., 1988; Wise et al., 1991; Breza and Wise, this volume). Transport over these distances through waters warmer than those of today at those latitudes requires large icebergs. Such icebergs must have been calved from ice sheets, not valley glaciers (Mercer, 1973, 1978).

6. During the Oligocene, grounded ice in both the Ross Sea and Prydz Bay extended well beyond the limits of the presentday ice front, thereby implying extensive ice in the form of an ice sheet (Barron, Larsen, et al., 1989; Barron et al., 1991a; Barrett et al., 1989).

7. Sedimentary evidence in CIROS-1 argues against a significant influence of sea ice on sedimentation in the western Ross Sea (Barrett, 1989; Barrett et al., 1989); therefore, a sea-ice mechanism may not have been a significant factor in the development of the psychrosphere, as suggested by Shackleton and Kennett (1975). The mere cooling of Antarctic 
A

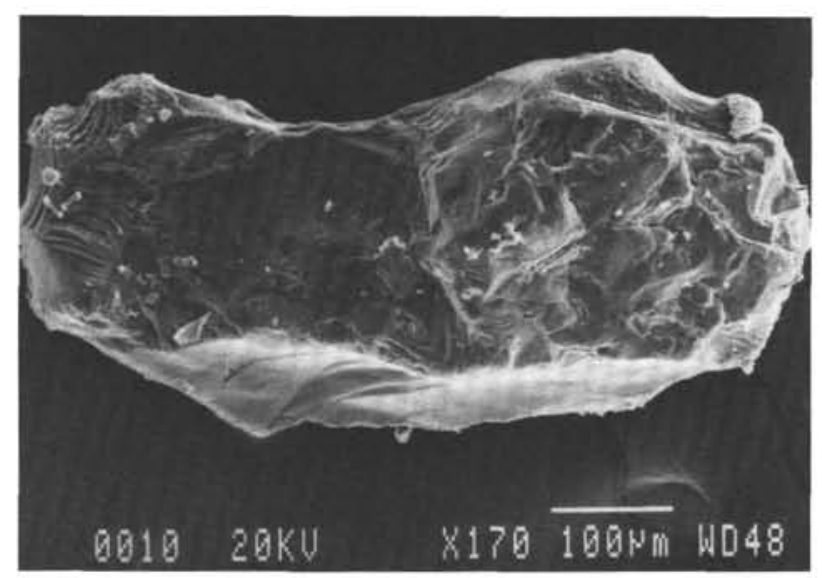

C

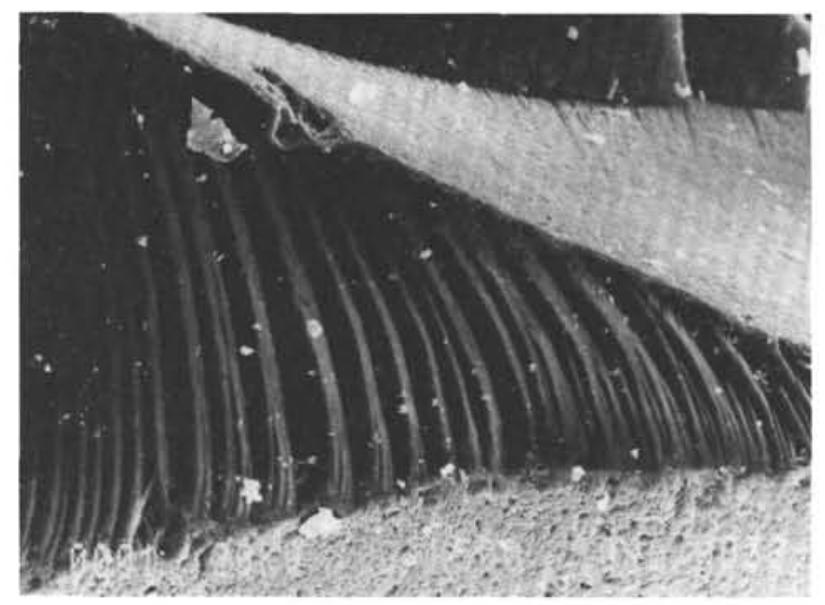

B

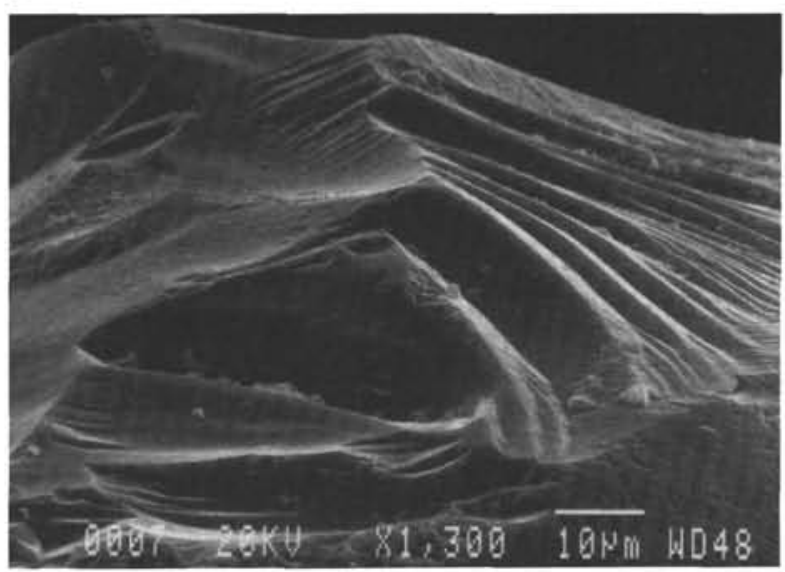

D

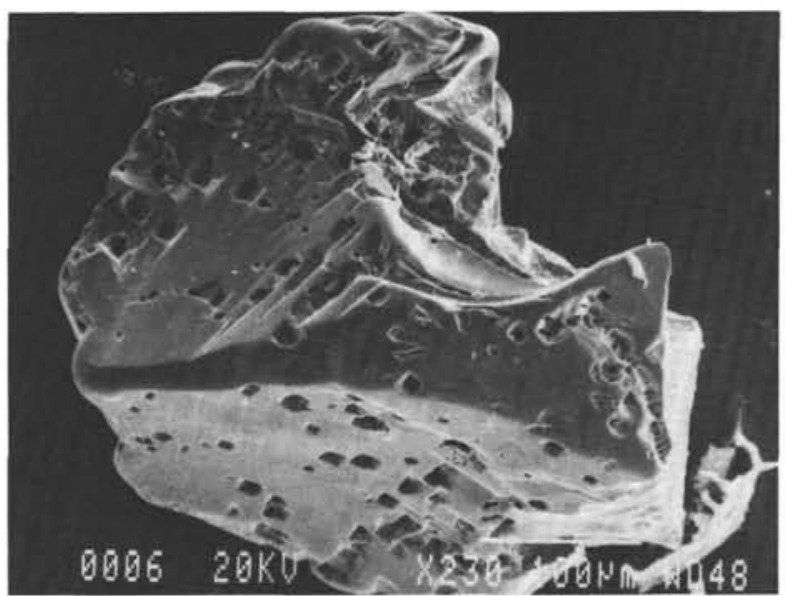

Figure 16. Scanning electron micrographs of sand-size clastic grains of IRD from the lower Oligocene siliceous nannofossil ooze stratum indicated in Figure 15 (from Breza and Wise, this volume). A. Quartz grain showing sharp angular outline and smooth dish-shaped conchoidal fractures, textures characteristic of glacial environments (Sample 120-748B-14H-2, 7-9 cm, $\times 120$ ). B. Quartz grain with arc-shaped, steplike fractures (Sample 120-748B-14H-1, 145-149 cm, ×900). C. Quartz grain with arc-shaped, steplike fractures bounded above and below by etch pits along the unbroken grain surface; fractures are characteristic of glacial environments (Sample 120-748B-14H-1, 145-149 cm, X400). D. Etched (V-shaped markings), subangular garnet grain indicative of a plutonic or metamorphic source on the East Antarctic craton (Sample 120-748B-14H-2, 7-9 cm, $\times 160$ ).

surface waters (as the coldest in the Oligocene ocean) and the profound effects of the grounding of the ice sheet at sea level might also suffice.

8. The absence of recycled upper Eocene or lower Oligocene marine microfossils in the Sirius Group tills of the Transantarctic Mountains (Fig. 9) may indicate that the interior seaways of Antarctica were covered by glacial ice at that time (Harwood et al., 1983; Webb et al., 1984), although emergence of the basins above sea level and limited recovery could also explain their absence.

Arguments against the presence of a significant early Oligocene ice sheet on Antarctica include the following:

1. There is no sedimentary evidence in the CIROS-1 cores to suggest extensive formation of sea ice in the Ross Sea (Barrett et al., 1989). This could imply that climate was not sufficiently cold to support an ice sheet. Sea ice can form in the absence of an ice sheet, as it does today in the northern Sea of Japan, which is the best ventilated of all marginal seas (Shipboard Scientific Party, 1990). Thus, winter-sea ice for- mation, even in moderate amounts, may account for the initiation of the psychrosphere during the earliest Oligocene (Shackleton and Kennett, 1975).

2. Beech forests continued to persist on Antarctica, at least in refugia, throughout the entire Oligocene (Kemp and Barrett, 1975; Mildenhall, 1989). This evidence, which includes a fossil Nothofagus leaf in the upper Oligocene of the CIROS-1 core (Hill, 1989), could imply mild climates and the absence of an ice sheet (Kennett, 1977). ${ }^{8}$

3. There is no profound sea-level drop recorded in the earliest Oligocene that would correspond to the formation of an ice sheet (see Vail et al., 1977; Haq et al., 1987). Elaborate models to explain this discrepancy with the stable isotopic record rely on seismic stratigraphic interpretation and still await rigorous testing (Miller et al., 1985).

\footnotetext{
${ }^{8}$ On the other hand, ice sheet modeling by Oerlemans (1982) suggests that continental scale ice sheets are still possible under conditions warm enough to support beech forests in Antarctica (Barrett et al., 1989). Evidence of beech vegetation is found in sediments as young as Pliocene (Webb and Harwood, 1987; see discussion by Bartek et al., 1991).
} 


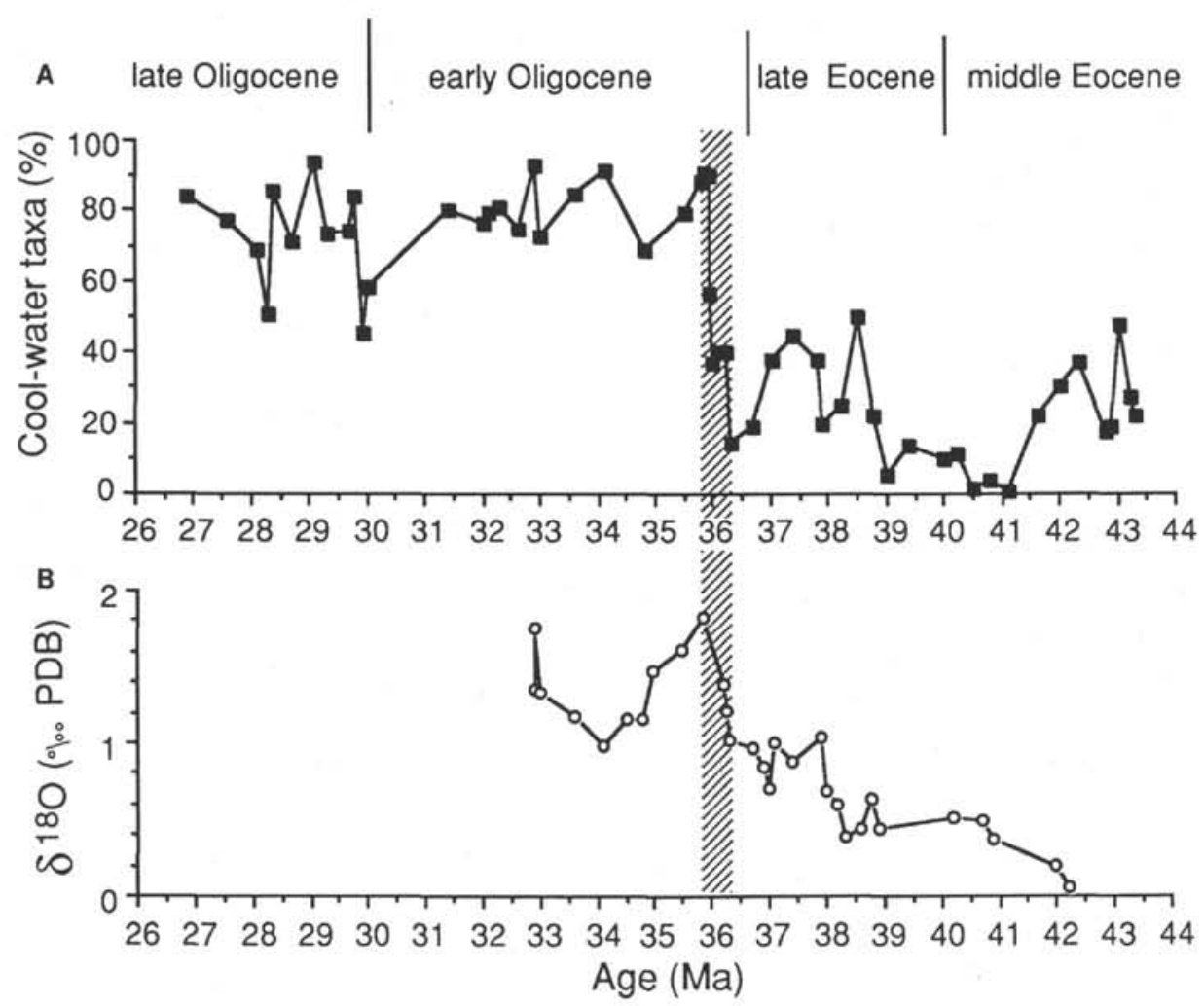

Figure 17. A. Abundance change of cool-water calcareous nannofossil taxa (chiasmoliths + Isthmolithus recurvus + Reticulofenestra daviesii) through time at Site 748 . B. Changes in $\delta^{18} \mathrm{O}$ values of planktonic foraminifers (Chiloguembelina cubensis) through time at this site (data from Zachos et al., this volume). Note the abrupt increase in cool-water taxa and the large positive shift in $\delta^{18} \mathrm{O}$ planktonic foraminiferal values indicated by the shaded bar (from Wei et al., this volume, fig. 13).

4. Conditions around Antarctica were sufficiently warm to allow the accumulation of nannofossils (sometimes of surprising diversity) in the Ross Sea and Prydz Bay during much of the early Oligocene (Edwards and Waghorn, 1989; Wei, this volume, Chapter 64; Wei and Thierstein, 1991) and of nannofossil ooze at Site 693 on the East Antarctic margin during the late Oligocene (Wei and Wise, 1990a). This may well imply the absence of an ice sheet.

5. The IRD along the Antarctic margin could have been transported by small but very "dirty" icebergs calved from valley glaciers.

6. The Oligocene IRD at Site 693 is volumetrically minor (Kennett and Barker, 1990); IRD at Site 748 represents a very short-lived event (Breza and Wise, this volume) that does not reoccur there until the late Miocene and could be of only local significance.

7. The stable isotope record is difficult to interpret, as it is inherently ambiguous, and detailed information is still lacking (Kennett and Barker, 1990). The available data can be interpreted reasonably without resorting to an appeal to a significant Oligocene ice sheet (Savin et al., 1975; Shackleton and Kennett, 1975; Savin, 1977; Woodruff et al., 1981). ${ }^{9}$

\footnotetext{
${ }^{9}$ Although Williams et al. (1985) accepted this interpretation, they noted that an ice-volume correction may eventually prove necessary. Oberhänsli and Toumarkine (1985, pp. 143-144) studied a transect of DSDP Leg 73 sites on the Walvis Ridge, but they avoided taking a position, noting the following: "The interpretation of the increase in Oxygen-18 at the Eocene/Oligocene boundary is still controversial. ... Further studies will prove whether, or to what extent, a continental glaciation contributed to this increase."
}

8. The present-day continental shelves of Antarctica have been eroded and depressed by the action and weight of the ice sheets; thus the shelf depths there are presently much deeper than along other continents. During the early Oligocene, the Antarctic shelves would have been much shallower; thus, it would be possible for valley glaciers to ground much farther out on these shelves relative to today (Wise et al., 1991; Anderson, in press; Anderson et al., 1991). No ice sheet, therefore, is needed to explain the fact that ice was grounded farther out into Prydz Bay and the Ross Sea during the Oligocene relative to today.

\section{Paleogeographic Reconstructions for the Early Oligocene}

At this writing, the majority of investigators favor the presence of not only a late Oligocene ice sheet, but of an early Oligocene ice sheet as well, at least as a temporary feature. The present authors share this view and envision a temperate ice sheet that underwent considerable growth and decay at various times during the Oligocene. Investigators agree that where independent lines of evidence coincide (e.g., where a strong positive oxygen isotopic shift is recorded in the same samples as appreciable IRD), then an ice sheet can be postulated, no matter how ephemeral it may have been. Such data for the earliest Oligocene at Site $\mathbf{7 4 8}$ on the Kerguelen Plateau is considered compelling evidence for the existence of a major ice sheet, even if for a limited time (Kennett and Barker, 1990).

The major remaining contention centers on the persistence and nature of the Oligocene ice sheet(s). More direct evidence 


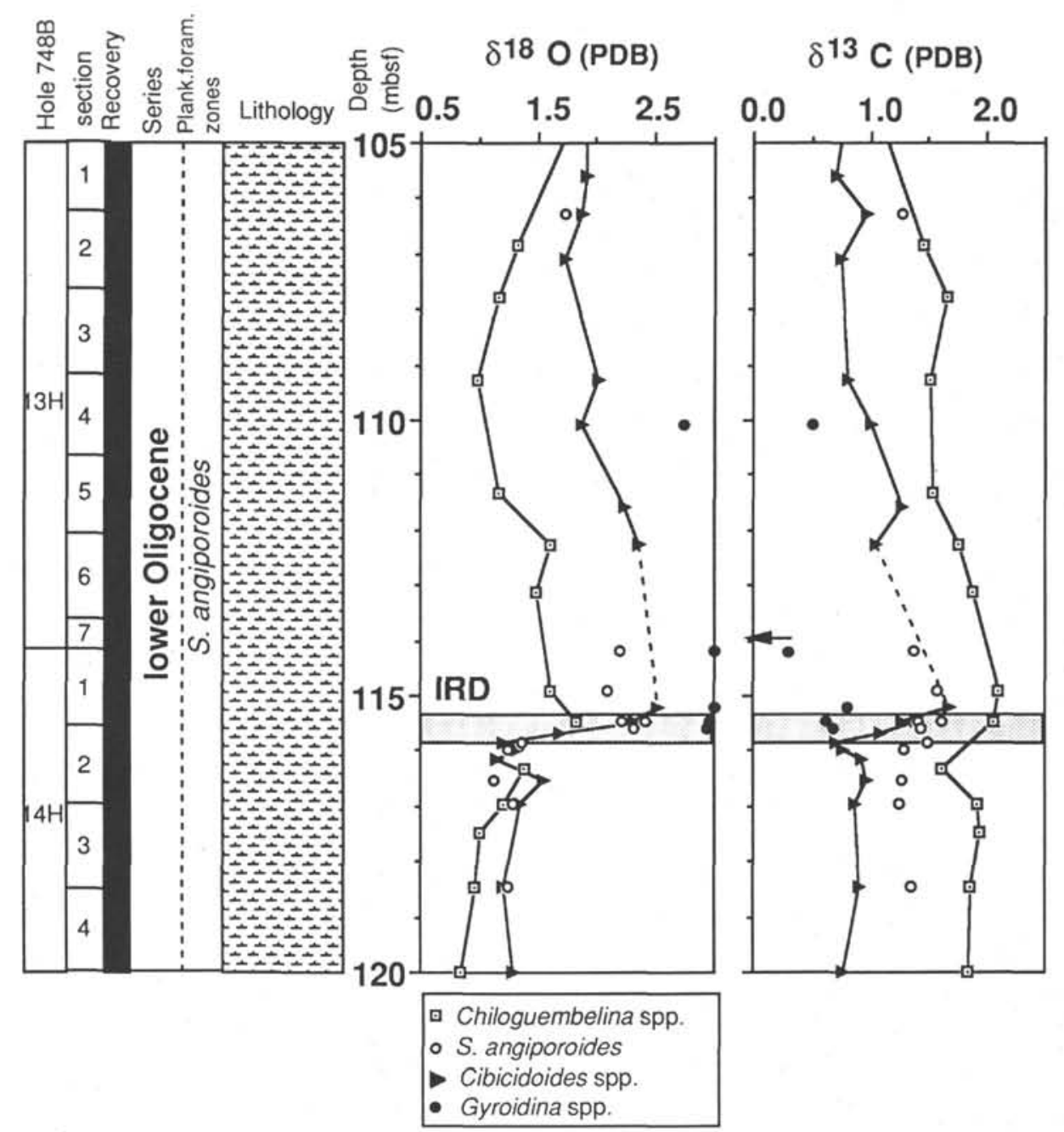

Figure 18. Percentages of carbonate and stable isotope data of ostracodes, and planktonic and benthic foraminifers plotted vs. depth across the middle Eocene-Oligocene interval at Site 748 (from Zachos et al., this volume, fig. 3).

from the continent is needed to settle this matter as well as such issues as the timing of deglaciations, including those suggested for the Pliocene.

If one does postulate the existence of Oligocene continental ice sheets, then there are additional questions to consider. For instance, some authors have speculated on the location, nature, and development of the ice sheet. On her paleogeographic maps, Kemp (1978) indicated an interior "ice cover" over east Antarctica near the Ross Sea during the early Oligocene and an "ice cap" that reached sea level along the southern Ross Sea and the coast of Wilkes Land during the late Oligocene. Kvasov and Verbitzky (1981) used modeling experiments to help calculate the size and position of the ice sheet since the beginning of the Oligocene. In their model Antarctic glaciation would have begun with a series of coalescing valley glaciers in the Gamburtzev Mountains (Fig. 9, “G"') (also see Denton et al., 1971). Kvasov and Verbitzky (1981) mapped several stages in a progressive growth of the ice sheet through the Oligocene-Miocene with a maximum expansion at $5 \mathrm{Ma}$, before an early Pliocene warming and possible disintegration of the West Antarctic ice sheet as postulated by Ciesielski and Weaver (1974; see also Footnote 2 and Fig. 2).

Webb et al. (1984) took into account the possibility of subglacial intracratonic basins on Antarctica (Fig. 10) and postulated the existence of interior seaways through this region during the nonglacial intervals of the Cenozoic; during glacial intervals these seaways would have been filled with ice. Harwood et al. (in press) believe numerous ice sheets of various sizes have developed over this region since at least the late Eocene. These authors concluded that the Oligocene through middle Pliocene ice sheets were "temperate" in nature and flat (pancake-like) in shape, and that colder, "polar" ice sheets (high, dome-shaped) as we know them today only developed during the past $2.4 \mathrm{~m}$.y. At that time glacial conditions intensified at both poles, leading to the reglaciation of Antarctica and the initiation of Northern Hemisphere glaciations. Because of this change in the character of the Antarctic ice sheets, they suggested that the present ice sheet and the processes by which it influences oceanic and continental records are not good analogs by which to characterize those of the Oligocene or Miocene.

Wise et al. (1985) also speculated on the probable location and extent of ice on the continent during the early Oligocene. They envisioned an intermediate stage between the presentday conditions and an "ice-free world," and they postulated the presence of a moderate-sized ice sheet on East Antarctica. They noted that ice sheets on both hemispheres today are not centered on, and probably were not initiated in, mountain 

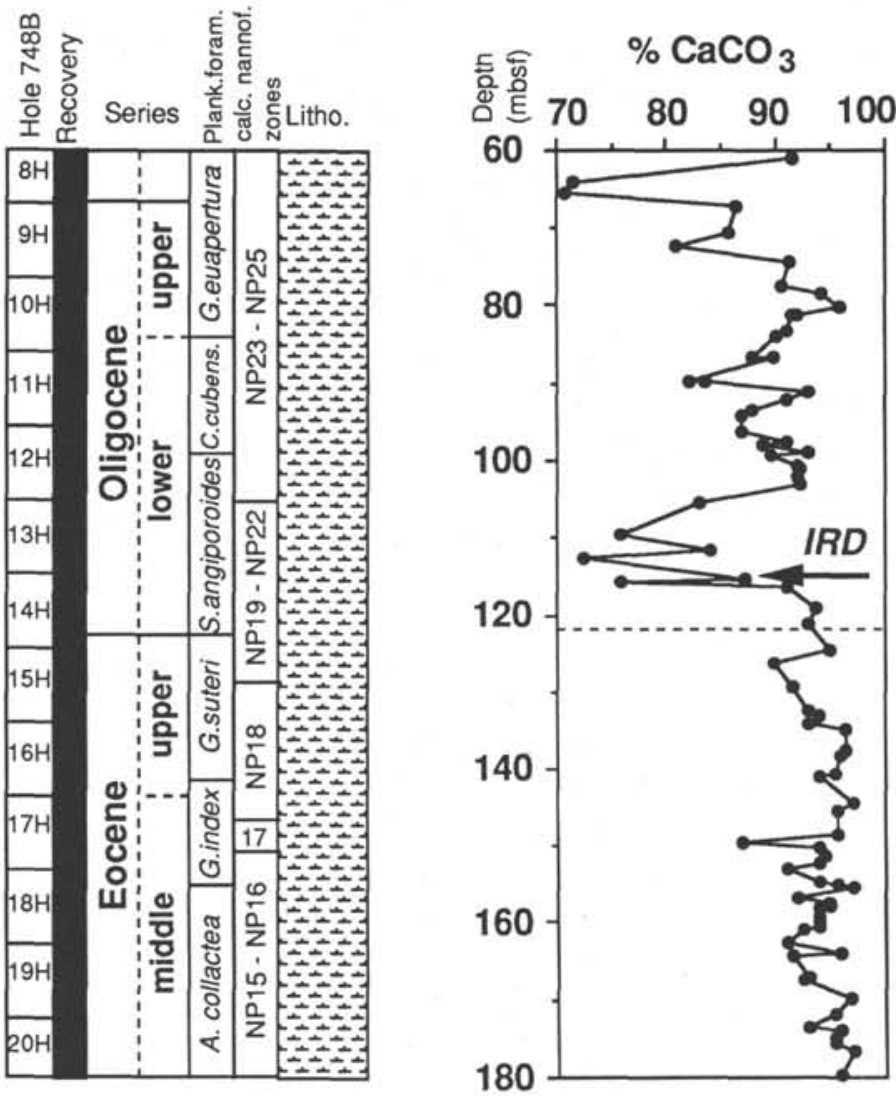

$\delta 180(\mathrm{PDB})$

$\delta^{13} \mathrm{C}(\mathrm{PDB})$

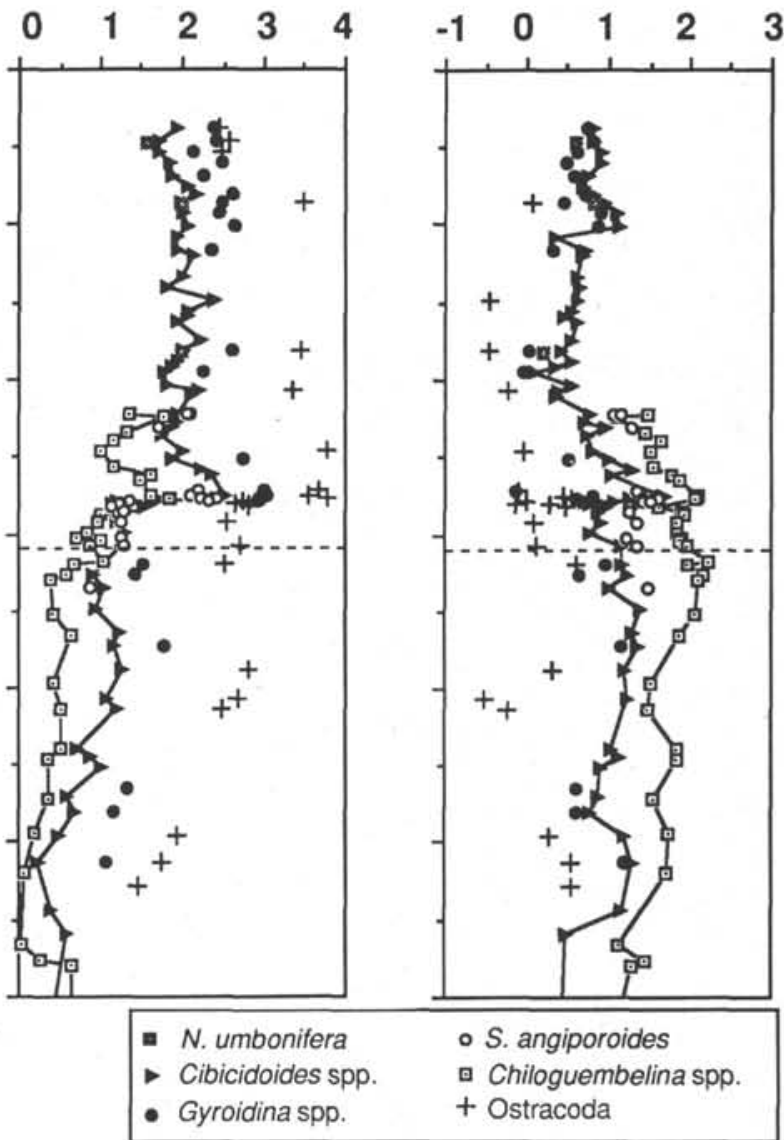

Figure 19. Correlation of Site 748 carbon and oxygen isotope data with occurrence of IRD in the lower Oligocene (from Zachos et al., this volume, fig. 5).

ranges but instead occupy the lowlands (Denton et al., 1971). Ice sheet formation in Antarctica during the Oligocene, therefore, probably began at comparatively low elevations $(2500$ $3000 \mathrm{~m}$ ) on plateaus of the East Antarctic craton. Such topographic highs are evident over this region on present-day subglacial maps (e.g., Drewry, 1983, and Fig. 10). In addition to low temperatures, moisture sources necessary to nourish the ice mass would likely have been the interior seas, such as those postulated by Zinsmeister (1978) and Webb et al. (1984) as well as the newly expanding seaway between Australia and Antarctica (Bartek, 1989; Bartek et al., in press). Like the North American and NW European Pleistocene ice sheets, the Antarctic ice sheet could have advanced and retreated great distances across the continent and onto the then shallower continental shelves over geologically short periods of time.

Wise et al. (1985) thought that the early Oligocene ice sheet was more or less "hidden" on the interior of the continent and that, if it did reach sea level, any ice-rafting would have been rather localized. As mentioned previously, however, the more recent drilling in the Weddell and Ross seas and off Prydz Bay has shown that ice-rafting did extend some distance beyond the continent. The IRD from Site 748 was recovered from a siliceous nannofossil ooze sequence; thus, the waters over the site must have been warmer during the early Oligocene than today. This would limit the travel distance of any icebergs and would require especially large icebergs to reach this location. The shortest travel distance would be for icebergs emanating from Prydz Bay, but any such bergs would have to travel north-northeast to reach the sites along the Kerguelen Plateau at which lower Oligocene IRD has been reported. This would require drifting against the prevailing circulation pattern (the east wind drift) in the region today. Either circulation patterns were quite different during the early Oligocene, or the bergs must have come from further east, perhaps as far way as the Ross Sea. The latter seems unlikely, however, considering that the surface temperatures were higher than today, and any bergs reaching the Kerguelen Plateau would have to be of extraordinary size, perhaps from shelf ice.

Kemp (1978) pointed out that the ice margin controls the position of the circumpolar easterlies. If only a moderate-size ice sheet were present and it reached the margin only briefly and intermittently during the earliest Oligocene, then the position of the easterlies may have fluctuated considerably in relation to the East Antarctic margin. Furthermore, Prydz Bay is today the most northerly of the Antarctic margin drill sites discussed (Fig. 20). According to some reconstructions (e.g., Scotese et al., 1988), it would have been positioned an additional $5^{\circ}$ farther north during the early Oligocene. Thus, the easterly Antarctic coastal current may have been only weakly developed or even absent in this region. The westerlies, therefore, were probably dominant offshore from the present-day Prydz Bay, and if the easterlies did move offshore during peak glacial events, they would have occupied only a narrow belt relative to today. It may have been quite possible for large bergs to have crossed this belt (if it did exist), to become entrained in the westerly current, and to eventually drift over the Southern Kerguelen Plateau as suggested in 


\begin{tabular}{|c|c|c|c|c|c|c|c|c|c|c|c|c|c|c|c|}
\hline \multirow{2}{*}{\begin{tabular}{|c|} 
Region \\
Site
\end{tabular}} & \multicolumn{3}{|c|}{ Ross Sea } & \multirow{2}{*}{\begin{tabular}{|c|}
$\begin{array}{c}\text { Marie } \\
\text { Byrd Land }\end{array}$ \\
$\begin{array}{c}\text { Mt. } \\
\text { Petras }\end{array}$ \\
\end{tabular}} & \multirow{2}{*}{$\begin{array}{c}\begin{array}{c}\text { Weddell } \\
\text { Sea }\end{array} \\
\mathrm{ODP} \\
693^{5}\end{array}$} & \multicolumn{2}{|c|}{$\begin{array}{l}\text { Prydz } \\
\text { Bay }\end{array}$} & \multicolumn{3}{|c|}{$\begin{array}{l}\text { Kerguelen } \\
\text { Plateau }\end{array}$} & \multirow{2}{*}{\begin{tabular}{|l|}
$\begin{array}{l}\text { Antarctic } \\
\text { Peninsula }\end{array}$ \\
$\begin{array}{l}\text { King } \\
\text { George } \\
\text { Island }\end{array}$ \\
\end{tabular}} & \multicolumn{4}{|c|}{ Southeast Pacific ${ }^{\circ}$} \\
\hline & $\begin{array}{l}\text { DSDP, } \\
270\end{array}$ & MSSTS-1 $1^{2}$ & CIROS-1 ${ }^{3}$ & & & $\begin{array}{l}\text { ODP } \\
739 \\
\end{array}$ & $\begin{array}{l}\text { ODP } \\
742\end{array}$ & $\begin{array}{l}\text { ODP } \\
738^{7}\end{array}$ & $\begin{array}{l}\text { ODP } \\
744^{7}\end{array}$ & $\begin{array}{l}\text { ODP } \\
748^{\circ} \\
\end{array}$ & & $\begin{array}{c}\text { Eltanin } \\
13-4\end{array}$ & $\begin{array}{c}\text { Eltanin } \\
24-8\end{array}$ & $\begin{array}{c}\text { Eltanin } \\
24.9\end{array}$ & $\begin{array}{c}\text { Eltanin } \\
24-10 \\
\end{array}$ \\
\hline Latitude & $77^{\circ} \mathrm{S}$ & $78^{\circ} \mathrm{S}$ & $77^{\circ} \mathrm{S}$ & $76^{\circ} \mathrm{S}$ & $71^{\circ} \mathrm{S}$ & $67^{\circ} \mathrm{S}$ & $67^{\circ} \mathrm{S}$ & $63^{\circ} \mathrm{S}$ & $62^{\circ} \mathrm{S}$ & $58^{\circ} \mathrm{S}$ & $62^{\circ} \mathrm{S}$ & $58^{\circ} \mathrm{S}$ & $43^{\circ} \mathrm{S}$ & $41^{\circ} \mathrm{S}$ & $38^{\circ} \mathrm{S}$ \\
\hline
\end{tabular}

$\delta^{18} \mathrm{O}(\% \circ \mathrm{PDB})$

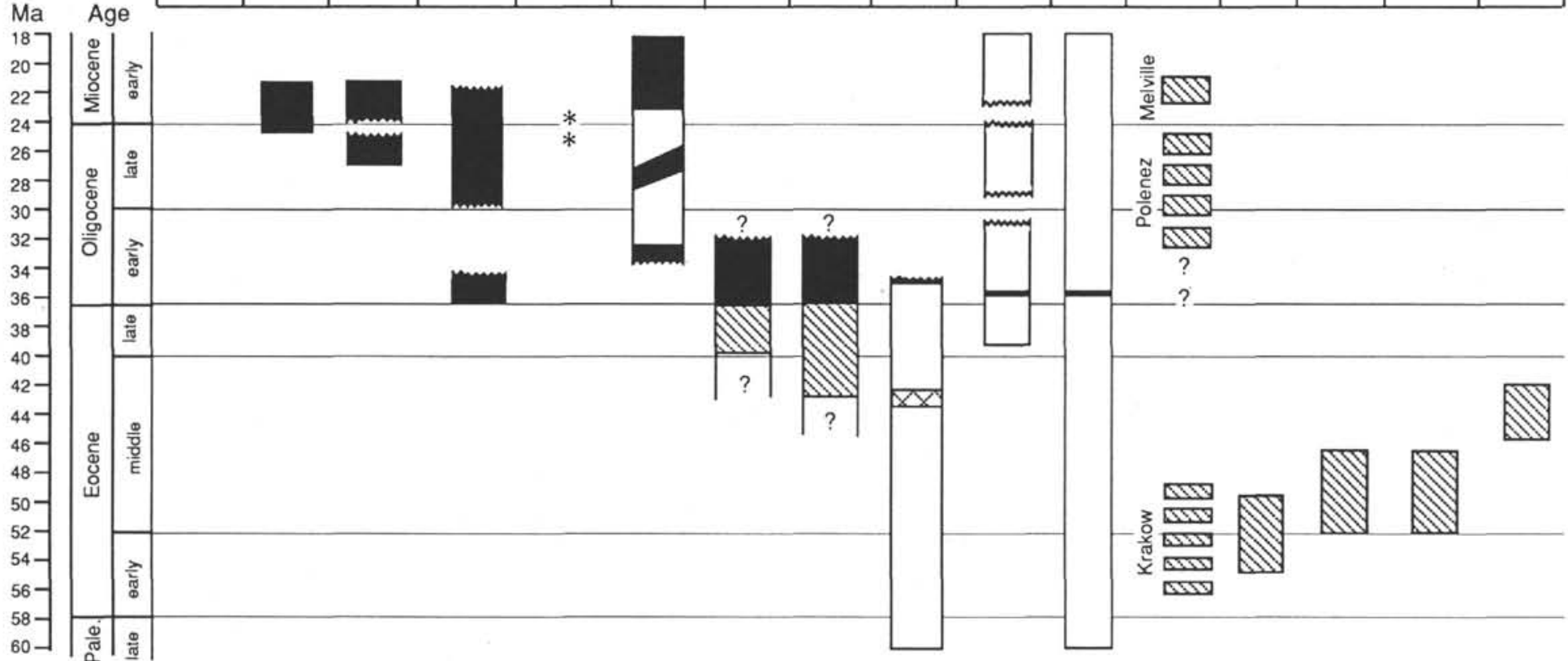
$3 \quad 2 \quad 1 \quad 0 \quad-1$

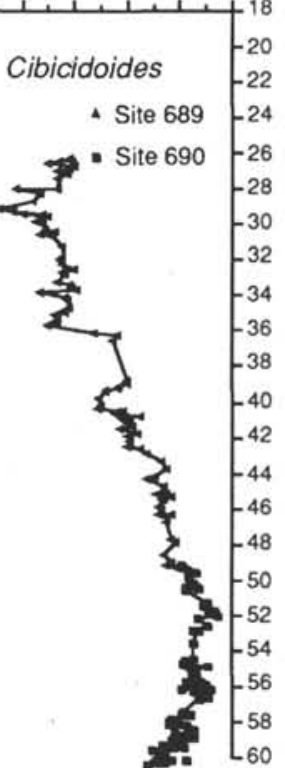
Reported glacial/glaciomarine sediment well documented and dated
NIV Reported glacial/glaciomarine sediment

XXV IRD considered to be mann Disconformity

* Hyaloclastite

Figure 20. Occurrences of known or suspected Paleogene IRD and glaciomarine sediments (after Wise et al., 1991). Oxygen isotope curve from Sites 689 and 690 (right) is from Kennett and Stott (1990). 1 = Hayes, Frakes, et al. (1975); 2 = Barrett (1986), Harwood et al. (1989a); 3 = Harwood et al. (1989a); $4=$ LeMasurier and Rex (1982, 1983); 5 = Barker, Kennett, et al. (1988); 6 = Barron et al. (1991a); 7 = Wei (this volume, Chapter 64); $8=$ Breza et al. (1988), Breza and Wise (this volume); $9=$ Birkenmajer et al. (1988); $10=$ Wei (this volume, Chapter 63); and $11=$ Ehrmann (1991). 

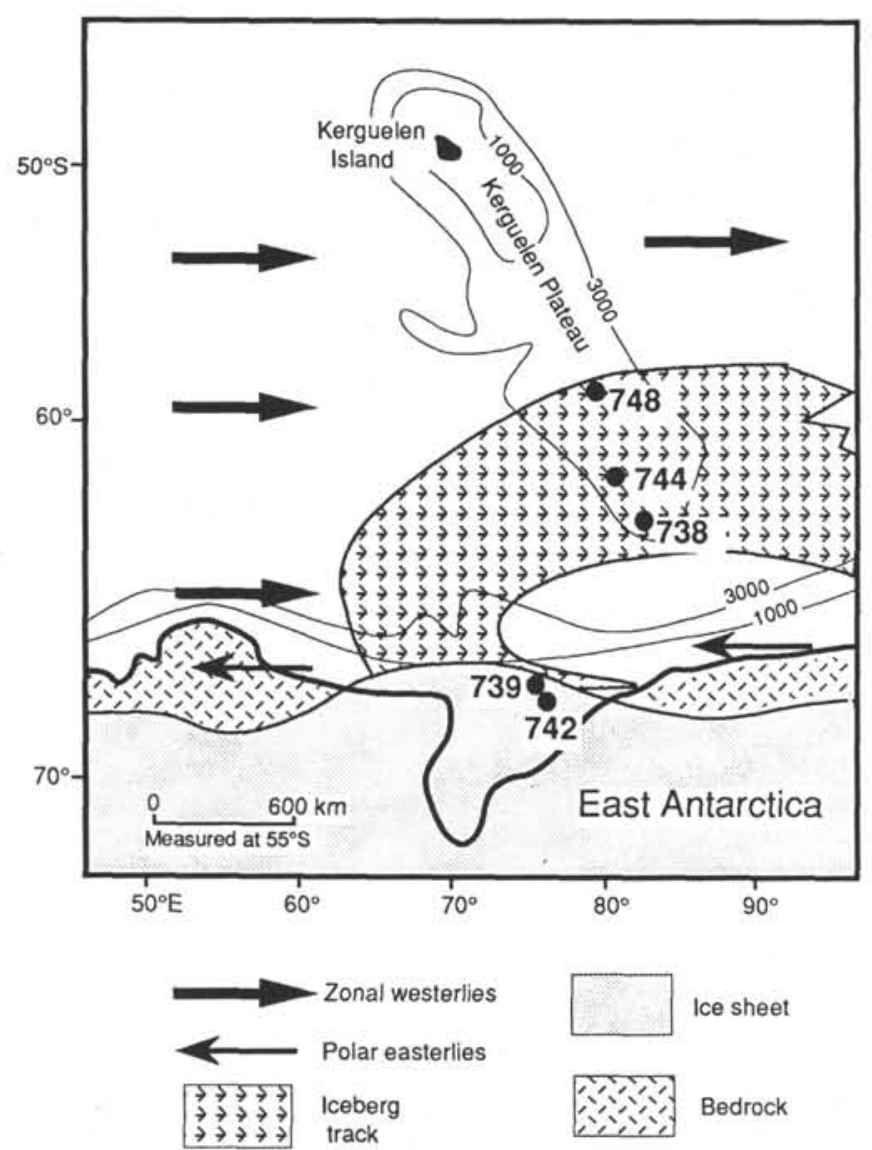

Figure 21. Speculative paleogeographic reconstruction for the Lambert Graben/Prydz Bay region for the earliest Oligocene ice advance showing a lobe of a moderate size East Antarctic ice sheet extending through the embayment toward the shelf break (Sites 739 and 742). The polar easterlies would tend to drift calving icebergs to the west, but the configuration of the shoreline would force surface currents north where the bergs would become entrained in currents driven by the zonal westerlies. Eventually the bergs would drift over the Kerguelen Plateau where lower Oligocene IRD has been observed at Sites 738,744 , and 748 .

Figure 21. If the easterlies were not well developed off Prydz Bay, the icebergs could have followed an even more direct track to the Southern Kerguelen Plateau.

Another interesting point for speculation is the relative size of the Oligocene ice sheet in comparison with the modern ice sheet and any that preceded it during the late Eocene. Zachos et al. (this volume) approach this problem by recalculating the latitudinal surface-water $\delta^{18} \mathrm{O}$ gradients of Keigwin and Corliss (1986; see Fig. 4) for the late Eocene and early Oligocene in view of the new high latitude isotopic data derived from their study and from Leg 113 to the Weddell Sea (Site 689, Maud Rise, $65^{\circ} \mathrm{S}$; Stott et al., 1990). The most negative planktonic foraminiferal $\delta^{18} \mathrm{O}$ values were chosen from each site to better reflect surface-water conditions, and the data for the late Eocene and early Oligocene were fit to polynomial (quadratic) regression curves (Fig. 22).

The early Oligocene high-latitude surface-water temperatures were clearly much lower than estimated by the original reconstruction of Keigwin and Corliss (1986), in agreement with the independent line of evidence offered by the nannofossil evidence from Legs 113 and 120 (Fig. 17 of this paper and fig. 14 from Wei et al., this volume). As noted previously,

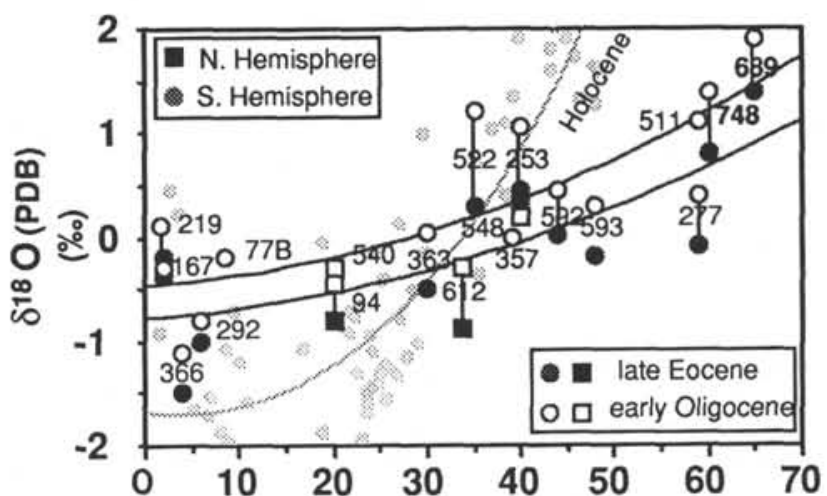

Figure 22. Latitudinal surface-water $\delta^{18} \mathrm{O}$ gradients of the late Eocene and early Oligocene (from Zachos et al., this volume, fig. 8). The $\delta^{18} \mathrm{O}$ values of surface-dwelling planktonic foraminifers are plotted vs. the "absolute" latitude of the site corrected for past plate motions.

however, it is difficult to estimate how much of the earliest Oligocene change in $\delta^{18} \mathrm{O}$ values for the planktonic and benthic foraminifers should be attributed to an ice-volume increase vs. a temperature decrease. At present, independent estimates derived from isotopic vs. biological latitudinal gradients provide somewhat different results.

Zachos et al. (this volume) find that the late Eocene and early Oligocene planktonic foraminiferal $\delta^{18} \mathrm{O}$ values from Sites 748 and 689 are as much as $0.75 \%$ to $1.0 \%$ ( $\left(3^{\circ}-4^{\circ} \mathrm{C}\right)$ higher than the values predicted from the gradients derived by Keigwin and Corliss (1986) (cf. Figs. 4 and 22), and the early Oligocene gradient shows a slightly greater slope than the late Eocene gradient toward the high latitudes (Fig. 22). The mean offset in latitudinal isotopic gradients from the late Eocene to early Oligocene at low latitudes is about $0.3 \%$ to $0.4 \%$, which Zachos et al. (this volume) suggest may be attributable to ice-volume change (assuming a constant tropical sea-surface temperature). The additional offset between the curves at $65^{\circ}$ latitude is $0.6 \%$. Zachos et al. (this volume) attribute the difference of $0.2 \%$ to $0.3 \%$ in the earliest Oligocene to lowered temperatures at the high latitudes. By similar reasoning, the $1.0 \%$ to $1.2 \%$ increase recorded by benthic foraminifers in the earliest Oligocene could represent the combined affects of a $3^{\circ}-4^{\circ} \mathrm{C}$ decrease in deep-water temperatures and a $0.4 \%$ ice-volume signal. This latter value agrees with the $0.4 \%$ o ice-volume effect suggested from isotope studies by Keigwin and Keller (1984) and Miller et al. (1987) and the $0.3 \% 0-0.5 \%$ correction by Wise et al. (1985).

After the global isotopic shift, the Oligocene benthic foraminiferal $\delta^{18} \mathrm{O}$ values from Site 748 (Fig. 19), as well as those from Sites 689 and 690 on Maud Rise $\left(1.94 \% \%_{-}-2.65 \%\right.$ according to Stott and Kennett, 1990), remain well above the threshold value of $1.8 \%$ that Miller et al. (1987) set for the existence of an Antarctic ice sheet. By this line of reasoning, one would have to assume the existence of such an ice sheet throughout the Oligocene, unless one assumes the possibility of higher salinity values rather than lower temperatures ( $\mathrm{Za}-$ chos et al., this volume). However, Wei and Wise (in press) argue that salinity values were probably lower rather than higher in the surface waters adjacent to Antarctica during the early Oligocene (see Fig. 4).

In contrast to the above, Wei et al. (this volume) attribute a much greater percentage of the surface-water isotopic change in the earliest Oligocene to temperature change. They note that the increase in the percentage of cool-water nannofossils at this time is the most drastic at anytime during the 


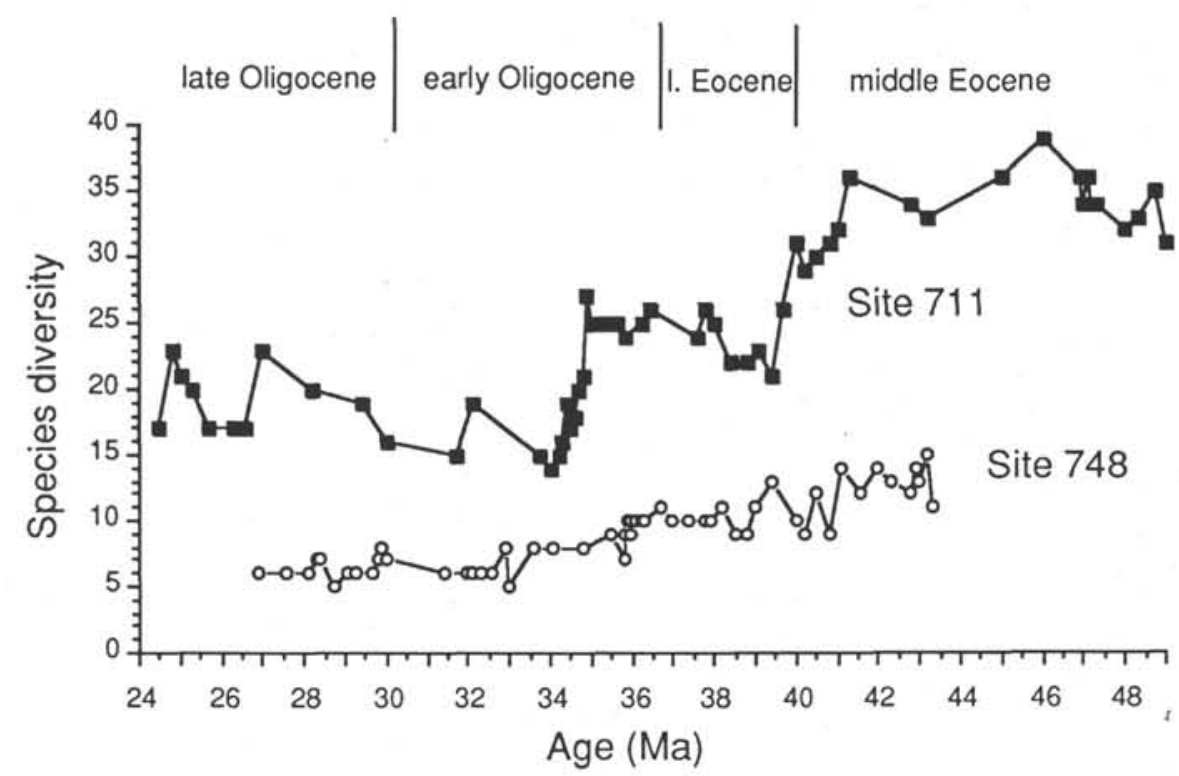

Figure 23. Calcareous nannofossil simple species diversity change through time, Sites 711 and 748 (from Wei et al., this volume).

Eocene-Oligocene interval (Fig. 17), a result mirrored at Site 689 at $65^{\circ} \mathrm{S}$ in the Weddell Sea (Wei et al., this volume, fig. 14). The latitudinal thermal gradient in the surface waters must have increased considerably at this time. These authors find that the abundance change of cool-water taxa at Site 748 (from ca. $20 \%$ to $>90 \%$ ) is comparable with the change from $\sim 30^{\circ}$ to $65^{\circ} \mathrm{S}$ latitude in the late Eocene South Atlantic, where a surface-water temperature difference of at least $4^{\circ} \mathrm{C}$ has been estimated (Shackleton and Boersma, 1981). If this value is accepted for this particular site, then the temperature drop would account for at least a $0.9 \%$ o increase in the $\delta^{18} \mathrm{O}$ values of planktonic foraminifers recorded by Zachos et al. (this volume). The remaining $0.1 \%$ o or less increase in $\delta^{18} \mathrm{O}$ values would then be attributed to an increase of ice volume on Antarctica (see further discussion by Wei et al., this volume).

The results of both of these methods of estimating temperature change and ice volume are considered preliminary, and a refinement of these methods and the resulting estimates is the subject of current research. High-resolution sampling, study of additional sites, improved statistical techniques for handling the data, and further attempts to account for salinity effects on the isotopic values as suggested by Wise et al. (1991; see also Fig. 4) may lead to useful refinements and a better resolution of the differences in the estimates produced by the two methods described above.

Dramatic cooling of the surface waters in the high latitudes surrounding the continent during the earliest Oligocene, however, is implied by both the stable isotopic and nannofossil data, and is the expected response for an ice sheet that reached sea level at several points around the continent. The effect was immediate and profound as it affected phytoplankton populations. One can postulate a similar effect on bottomwater isotopic values, and Boersma (1985, and references therein) suggested a migration of deep water benthic foraminifers to shallower depths as a result of cooling of deep water masses. Nevertheless, benthic foraminiferal and ostracod assemblages were little affected in terms of faunal turnover and species diversity (Thomas, 1990, and references therein; Benson, 1975, Benson et al., 1985). How could such a major environmental event not have a more drastic effect on these benthic organisms? The answer may lie in the fact that the earliest Oligocene decrease in high-latitude temperatures was small in comparison with the longer term trend for the Eocene, where benthic values increased as much as $1.50 \%$ (Figs. 2 and 20). Low-latitude values had increased by about $0.5 \%$. This may suggest that Eocene benthic foraminiferal assemblages had already been exposed to considerable cooling, particularly in the high latitudes, and major faunal overturn on the Kerguelen Plateau and elsewhere had already taken place starting in the late middle Eocene (Mackensen and Berggren, this volume). In this sense, the early Oligocene benthic faunas may have been preadapted to the trauma of further cooling and, thus were little affected by the earliest Oligocene event. Similarly, the nannofossil assemblages showed little change in diversity at either high or low latitudes (Fig. 23), although the extinction of large-bodied, many-rayed discoasters (Discoaster barbadiensis and D. saipanensis) occurred close to the Eocene/Oligocene boundary at low latitudes (Bukry, 1973).

The above explanation may not be considered satisfactory to specialists who work with benthic faunas, and more research clearly needs to be done on this problem. To date, the high latitude nannoplankton are the only surface-water group that has been documented to show a drastic change in the earliest Oligocene (Wei et al., this volume) coincident with the dramatic shift in the isotopic composition of the benthic and planktonic foraminifers. Similar analyses need to be performed on the high latitude planktonic foraminifers to see if they exhibit a similar rapid assemblage change in the earliest Oligocene.

Another question that has been pondered is the triggering mechanism that produced the formation of the first ice sheet on the continent. Kennett (1977) suggested that the development of the Antarctic Ocean by plate tectonics isolated Antarctica and led to its cooling and subsequent cryospheric development. The cooling began around 52-53 Ma (Fig. 20), and the development of the Tasmanian seaway may have led to the Eocene/Oligocene cryospheric threshold event (Kennett, 1977). Bartek (1989) and Bartek et al. (in press) suggest that in addition to the thermal isolation of Antarctica, the development of the seaway between Antarctica and the Aus- 
tro-New Zealand landmasses produced an atmospheric system that allowed ice-sheet formation. By this model, seasonal low pressure systems along the Antarctic coast would have produced onshore winds that transported moist air onto the cold interior of the continent, increasing precipitation and leading to the formation of the first ice sheet. Zachos et al. (this volume) review this type of "snow gun" hypothesis in light of ice-sheet size and critical temperatures at the ice margin or in the surrounding oceans. Bartek (1989) and Bartek et al. (in press) and others argue that ice-sheet formation may have begun as early as the late Eocene.

\section{Eocene Glacial Ice?}

If an ice sheet did exist on Antarctica during the earliest Oligocene, could one have been present there during the Eocene? Even before DSDP drilling in the Southern Ocean, there were reports of ice-rafting during the Eocene. Margolis and Kennett (1971) reported scattered quartz grains with surface textures considered indicative of glacial environments in lower to middle Eocene nannofossil oozes recovered in Eltanin piston cores from the southeast Pacific Ocean. These cores were taken at present-day latitudes between $38^{\circ}$ and $57^{\circ} \mathrm{S}$. In addition to the surprisingly low latitudes of some of the cores $\left(38^{\circ} \mathrm{S}\right.$, beyond the present-day limits of ice-rafting), there is the possibility that the quartz grains could be Quaternary contaminants introduced from the top of the sequences by the coring process. Mercer $(1973,1978)$ argued that botanical and oxygen isotopic evidence suggested incompatibly warm early Eocene paleoclimates for ice-rafting to the mid latitudes, that the sands could have been introduced from shelfal areas by turbidites, and that unless independent confirming evidence is presented, the hypothesis of ice-rafting for these clastics could not be accepted. The cores have been reexamined by Wei (this volume, Chapter 63), who states that downcore contamination is unlikely, particularly for Eltanin Core 24-10, which apparently penetrated no Neogene sediment. He also applied modern nannofossil zonations to confirm and refine the early-middle Eocene age dates for the cores, the stratigraphic positions of which are plotted in Figure 20.

In addition to the above, Birkenmajer et al. (1986) reported a tillite on King George Island in the northern Antarctic Peninsula beneath a lava flow dated at $49.4 \pm 5$ Ma (their "Krakow" glaciation). One can assign a maximum Eocene age to this material, which contains reworked Cretaceous and Paleogene coccoliths, the youngest of which are early Eocene in age, according to Birkenmajer et al. (1988). If the age of this material could be better constrained, it might indicate a local alpine glacial source for the IRD reported by Margolis and Kennett (1971). As mentioned previously, however, Mercer $(1973,1978)$ contended that only ice sheets are capable of producing bergs large enough to survive drift through warm waters to the mid latitudes, and that the available evidence for Eocene paleoclimates did not support the existence of such ice sheets. In this respect, the trend of the more recently acquired stable isotope record of Eocene paleoclimates (Fig. 20, right; see also Stott et al., 1990, and Zachos et al., this volume) is not significantly different from those available to Mercer (Fig. 2). By the same logic, however, it can be argued that, if the evidence of Margolis and Kennett for IRD is valid, then an Eocene ice sheet must have existed (Wei, this volume, Chapter 63).

Both Kennett (1978) and Kemp (1978) considered limited ice cover on Antarctica during the Eocene a distinct possibility, but they thought that it may have been confined to alpine glaciers in elevated coastal areas, such as West Antarctica (Kennett and Shackleton, 1976). Kemp, however, also spec- ulated that limited ice development occurred near the pole and adjacent to the Ross Sea (Kemp, 1978, fig. 5).

Although the oldest firm dates for the glaciomarine sediments drilled at CIROS-1 (Barrett et al., 1989) and in Prydz Bay (Barron, Larsen, et al., 1989) are earliest Oligocene in age, older undated glacial sediments exist below those welldated intervals, and there has been speculation that these units could be upper Eocene or possibly middle Eocene in age. Edwards and Waghorn (1989) suggested as much for the CIROS-1 core, although Wei (this volume, Chapter 64) found upper Eocene-lower Oligocene assemblages in the sequence. Barron et al. (1991b; see also Leg 119 Shipboard Scientific Party, 1988) present paleomagnetic correlations which, if correct, indicate an age of $41 \mathrm{Ma}$ for the base of Site 742 in Prydz Bay. In support of the notion of late Eocene continental glaciation, Harwood et al. (in press) noted that the first clear covariance in two key ice-volume proxies (positive oxygen isotope trends and low sea levels) occur during the earliest late Eocene.

Barron, Larsen, et al. (1989) also noted isolated clasts at the tops of some Eocene cores from the southern Kerguelen Plateau Sites 738 and 744 , but commented that these may be downhole contaminants. Among these, Ehrmann (1991) reported gneissic or granitic rock fragments from Sections 119-738B-13H-1 and $-11 \mathrm{H}-1$ as well as terrigenous sand grains from Sections $119-738 \mathrm{~B}-13 \mathrm{H}-1$ and $-14 \mathrm{X}-1$. He assumed that this material, in sediments dated as middle Eocene (42.5-43.5 $\mathrm{Ma})$, had been transported by icebergs and that isolated valley glaciers on Antarctica had reached sea level at this time. The second author of this paper reexamined these cores and confirmed the presence of Neogene contaminants, many of them manganese coated, in these intervals. The Eocene samples in question listed by Ehrmann (1991, appendix 4) had all been taken near the top of each core (Section 1, 48-52 cm) during routine shipboard sampling, and the sampling devices had penetrated to the core liners where they apparently encountered most of the contaminants. Such contaminants commonly cave downhole from the surface between coring runs, and end up incorporated in the top of the next core taken.

Thus, although the results of ODP drilling at Sites 739 and 742 in Prydz Bay suggest the possibility of middle to late Eocene glacial activity, the reported early to middle Eocene occurrences of IRD remain problematic. Nevertheless, the stable isotope record shows a major cooling during the earlymiddle Eocene (Shackleton and Kennett, 1975; Oberhänsli et al., 1984) that may coincide with a major sea-level drop (Vail et al., 1977; Haq et al., 1987). A major canyon-cutting episode has been suggested for this interval along continental margins (Miller et al., 1987, 1990), which is also a time of cooling and diminished diversity among calcareous microfloras in the high southern latitudes (Pospichal and Wise, 1990; Kennett and Barker, 1990). Of the several Eltanin cores redated by Wei (this volume, Chapter 64), Core $24-10$ is the most likely to contain in situ IRD because there is no Neogene material upsection to serve as a possible source of contamination. The lower age range assigned this core coincides with a stepwise drop in benthic $\delta^{18} \mathrm{O}$ values at about 42-43 Ma (Fig. 20).

Evidence in the way of a "smoking gun" for Eocene continental glaciation, however, has yet to be recognized. Nevertheless, in the eyes of some workers this is just a matter of time and future exploration. Modeling experiments of Cretaceous and Eocene climates by Barron et al. (1981), Barron (1987), and Sloan and Barron (1990) indicate how difficult it would be to maintain "equable" global climates above freezing at middle and high latitudes, particularly within continental interiors, unless currently unknown forcing mech- 
anisms influenced past climates. Frakes and Francis (1988) recently reviewed the Phanerozoic record of ice-rafted deposits and concluded that ice-rafted sediments can be found at high paleolatitudes for all systems except for the Triassic, and that the possibility that an ice-free Earth ever existed appears to be small.

\section{SUMMARY AND CONCLUSIONS}

The Paleogene cryospheric history of Antarctica continues to be an intriguing but controversial topic because of a general dependence on indirect evidence of glaciation, such as the "proxy" stable isotopic record from the world's oceans, the occurrence of clastic materials in the Southern Ocean variously interpreted as IRD, changes in clay mineral assemblages, changes in the diversities of microfossil assemblages and in the steepness of latitudinal biotic gradients, the presence of hiatuses in the deep-sea record, and correlations with eustatic sea-level curves. Together with modeling studies, seismic stratigraphic analyses of continental margin sequences, and studies of Tertiary outcrops on land, these widely disparate lines of evidence studied by an equally diverse array of specialists represent data bases fragmented across widely separated geographic regions and disciplinary fields. This disparity of methods, approaches, and data bases has inevitably engendered controversy (Bartek, 1989; Bartek et al., in press).

Controversy has been beneficial because the questions raised have fueled the need not only for interdisciplinary studies and international cooperation, but for more detailed data of higher quality and for more direct evidence of glacial history from the Antarctic continent itself. The pertinent data bases rapidly expanded during the 1980 s and continue to do so (1) through renewed efforts at drilling in the Southern Ocean and along the continental margins and marginal seas of Antarctica; (2) through the acquisition of more detailed stable isotope records from high-quality (HPC and APC) drill cores, including those acquired during Legs 113,119 , and 120 ; (3) through the discovery of recycled microfossils in younger till deposits on Antarctica; and (4) through the radiometric dating of till/lava sequences in the Antarctic Peninsula. These studies have brought to light considerable new evidence of Paleogene glaciation and have pushed evidence for such glaciation further back in time.

Most investigators believe that continental ice sheets were present on East Antarctica during the Oligocene, including the earliest Oligocene. They were not necessarily permanent features, but probably went through many advances and contractions and may have disappeared completely at times (Harwood et al., in press). They almost certainly disappeared at some point during the early Miocene (Kemp and Barrett, 1975; Miller et al., 1987; Harwood et al., 1989b).

Through its rapid advance during the earliest Oligocene, an ice sheet(s) reached sea level at several widely scattered localities around the continent but perhaps only briefly at some locations. According to current age models, two episodes of ice-rafting are recorded on the Kerguelen Plateau, each about $1 \mathrm{~m} . \mathrm{y}$. apart (Appendix). There is no strong indication of the earliest Oligocene event in the eustatic sea-level record of many areas, perhaps due to the brevity of the advances. Alternatively, and probably more likely, evidence of an earliest Oligocene sea-level drop has been removed or obscured by the more widely recognized midOligocene eustatic event (Vail et al., 1977).

Nevertheless, the effect of ice reaching sea level at several points around the continent was immediate and profound, causing significant reorganization of circulation systems (see discussions by Breza et al. and Zachos et al., this volume) and a sharp cooling of surface waters around the continent, as noted in the surface dwelling nannoplankton assemblages and in the stable isotopic records of planktonic foraminifers. In addition, there were changes in clay-mineral assemblages and $\mathrm{CaCO}_{3}$ contents of the sequence containing the IRD. Ehrmann (1991) notes that the clay-mineral change precedes the arrival of Oligocene IRD on the Kerguelen Plateau, suggesting that rivers were carrying the products of a physical weathering regime to the sea ahead of the ice advancing over the continent.

The magnitude and extent of the early Oligocene cryospheric events seem to have been underestimated in some previous studies. At Site 693 and those studied on the Kerguelen Plateau, the amount of lower Oligocene IRD deposited was not equaled or exceeded until late Miocene or early Pliocene times. This is in contrast to the record in the CIROS-1 core of the Ross Sea where there is a considerable increase in glacial debris in the middle Oligocene, a phenomenon not seen in the IRD record of the Weddell Sea or on the Kerguelen Plateau. This could reflect changes in iceberg tracks or a diminution of glacial activity in these local areas following the early Oligocene. An alternative hypothesis could be that much easily erodible regolith material was removed during the initial ice advance of the early Oligocene, leaving a diminished supply on the denuded bed-rock surface to be incorporated during subsequent glacial episodes (Warnke, 1970; Ehrmann, 1991).

The Oligocene ice sheets were temperate in nature; thus, they probably exhibited different shape and flow characteristics compared with the "polar"' ice sheet on Antarctica today. Although Oligocene climates were milder than those of today, the ice sheets apparently could have grounded farther out on the continental margins because the shelves were shallower in the Paleogene than they are today (Anderson, in press; Anderson et al., 1991).

A major unresolved question is "how can one reliably partition the temperature and ice-volume signals responsible for the earliest Oligocene $\delta^{18} \mathrm{O}$ shift?"' By analyzing Eocene and Oligocene latitudinal isotopic gradients, Zachos et al. (this volume) attribute about $0.4 \%$ of the shift to an ice volume effect. Thomas (1991) favors a relatively large ice volume signal such as this because she sees no major and sudden corresponding assemblage changes in the way of extinctions and diversity changes among the benthic foraminifers, as would be expected from a major temperature change. On the other hand, Wei et al. (this volume) attribute up to $0.9 \%$ or $90 \%$ (rather than only $60 \%$ ) of the isotopic signal in the surface waters to temperature change rather than to ice volume, and this is more compatible with the rather modest sea level change recorded for the earliest Oligocene in the Vail sea level curve (Haq et al., 1987). The truth may lie somewhere in between these views. A holistic approach to the problem, incorporating as many independent lines of evidence as possible, will be necessary to provide a better estimate of the components that make up the isotopic signal. Better isotopic data from the equatorial latitudes is also badly needed as few high resolution data for gradient studies exist from that region.

Tantalizing evidence in the way of undated till deposits below well-dated lower Oligocene glaciomarine sequences along the Antarctic margin and possible IRD beyond (Fig. 20) suggest the presence of glaciers during the late Eocene and possibly during the early-middle Eocene. There is no agreement as to whether an ice sheet was present at any time during the Eocene, however, particularly during the early-middle Eocene. Breza et al. (1989) contended that the evidence from Site 748 constituted the "smoking gun" that proved conclu- 
sively the existence of an earliest Oligocene ice sheet on Antarctica. The as-yet-undated diamictites below lower Oligocene sequences at Prydz Bay Sites 739 and 742 may eventually prove to be the "smoking gun" that will indicate the presence of a late Eocene ice sheet. However, current technology and the inability to obtain conclusive age dates on this sequence have not allowed the "smoke" to be detected, if indeed it exists.

Because of the crucial role of Antarctic glaciation in the climatic history of the planet, exploration efforts should continue if we are to answer the outstanding questions that continue to fuel controversy: When did Cenozoic Antarctic glaciation begin, when did an ice sheet first form, and what has been the history of this ice sheet(s)? Clearly Antarctica has had a long Cenozoic cryospheric history. The quest now is for more detailed knowledge of that history. As enumerated by Kennett and Barker (1990), there are several elements that make up the cryosphere (alpine and coastal glaciers, small ice sheets, land- and marine-based major ice sheets, ice shelves, and various degrees of sea ice development). A major goal is to identify better these elements in the geologic record so that more refined and detailed histories of Antarctic glaciation can be written. To refine the Paleogene glacial record further will require concerted efforts on an international scale (Webb, 1990), for which this latest series of ODP Antarctic cruises concluded by Leg 120 provides a significantly broader foundation and perspective from which to plan.

\section{ACKNOWLEDGMENTS}

We are grateful to John B. Anderson, James P. Kennett, David Lazarus, Suzanne O'Connell, and Ellen Thomas for thorough and helpful critical reviews of this paper. Eva M. Barbu provided a most conscientious editor's review on this and the other papers we submitted to this volume; Kim Hall assisted in many ways. Much of the manuscript was derived from a paper by Wise et al. (1991), which was incorporated here with little modification of figures or wording, and we thank Academic Press for permission to reproduce figures and text that appeared in that article. These include Figures 1-16 and 20-21 from the present paper. Dr. Suzanne O'Connell kindly took the photographs of ODP Leg 113 cores. Mr. Dennis Cassidy, Curator of the FSU Antarctic Research Facility, provided numerous literature references and Antarctic piston core samples, which complemented those provided by the Ocean Drilling Program. The study was supported by NSF Grant No. DPP 8917976, USSAC funds, and an equipment grant from the Amoco Foundation.

\section{REFERENCES}

Anderson, J. B., in press. The antarctic continental shelf: results from recent marine geologic and geophysical investigations. In Tingey, R. (Ed.), Antarctic Geology: Oxford (Oxford Univ. Press).

Anderson, J. B., Bartek, L. R., and Thomas, M. A., 1991. Seismic and sedimentologic record of glacial events on the Antarctic Peninsula shelf. In Thomson, M. R. A., Crame, J. K., and Thomson, J. W. (Eds.), Geological Evolution of Antarctica: Cambridge (Cambridge Univ. Press), 687-691.

Barker, P. F., Carlson, R. L., Johnson, D. A., et al., 1983. Init. Repts. DSDP, 72: Washington (U.S. Govt. Printing Office).

Barker, P. F., Kennett, J. P., et al., 1988. Proc. ODP, Init. Repts., 113: College Station, TX (Ocean Drilling Program).

1990. Proc. ODP, Sci. Results, 113: College Station, TX (Ocean Drilling Program).

Barker, P. F., Kennett, J. P., and Leg 113 Shipboard Scientific Party, 1988. Weddell Sea palaeoceanography: preliminary results of ODP Leg 113. Palaeogeogr., Palaeoclimatol., Palaeoecol., 67:75-102.
Barrera, E., and Huber, B. T., 1991. Paleogene and early Neogene oceanography of the southern Indian Ocean: Leg 119 foraminifer stable isotope results. In Barron, J., Larsen, B., et al., Proc. ODP, Sci. Results, 119: College Station, TX (Ocean Drilling Program), 693-718.

Barrett, P. J. (Ed.), 1986. Antarctic Cenozoic history from the MSSTS-1 drillhole, McMurdo Sound. DSIR Bull. N. Z., 237:1171.

1989. Antarctic Cenozoic history from the CIROS-1 drillhole, McMurdo Sound. DSIR Bull. N. Z., 245:1-254.

, in press. Antarctica and global climate change-a geological perspective. In Harris, C. M., and Stonehouse, B. (Eds.), Antarctic and Global Climatic Change: Cambridge (Scott Polar Res. Inst. and Belhaven Press).

Barrett, P. J., Elston, D. P., Harwood, D. M., McKelvey, B. C., and Webb, P.-N., 1987a. Mid-Cenozoic record of glaciation and sealevel change on the margin of the Victoria Land basin, Antarctica. Geology, 15:634-637.

Barrett, P. J., Hall, K. J., Hambrey, M. J., Pyne, A. R., and Robinson, P. H., 1987b. Cenozoic glacial and tectonic history from CIROS-1, McMurdo Sound. 5th Int. Symp. Antarct. Earth Sci., Cambridge, 12. (Abstract)

Barrett, P. J., Hambrey, M. J., Harwood, D. M., Pyne, A. R., and Webb, P.-N., 1989. Synthesis. In Barrett, P. J. (Ed.), Antarctic Cenozoic History from CIROS-1 Drill Hole, McMurdo Sound. DSIR Bull. N.Z., 45:241-251.

Barrett, P. J., Hambrey, M. J., and Robinson, P. H., 1991. Cenozoic glacial and tectonic history from CIROS-1, McMurdo Sound. In Thomson, M.R.A., Crame, J. K., and Thomson, J. W. (Eds.), Geological Evolution of Antarctica: Cambridge (Cambridge Univ. Press), 651-656.

Barron, E. J., 1987. Eocene equator-to-pole surface ocean temperatures: a significant climate problem? Paleoceanography, 2:729739.

Barron, E. J., and Peterson, W. H., 1991. The Cenozoic ocean circulation based on ocean General Circulation Model results. Palaeogeogr., Palaeoclimatol., Palaeoecol., 83:1-28.

Barron, E. J., Thompson, S. L., and Schneider, S. H., 1981. An ice-free Cretaceous? results from climate model simulations. Science, 212:501-508.

Barron, J., Larsen, B., et al., 1989. Proc. ODP, Init. Repts., 119: College Station, TX (Ocean Drilling Program).

Barron, J., Larsen, B., and Baldauf, J. G., 1991a. Evidence for late Eocene to early Oligocene Antarctic glaciation and observations on late Neogene glacial history of Antarctica: results from Leg 119. In Barron, J., Larsen, B., et al., Proc. ODP, Sci. Results, 119: College Station, TX (Ocean Drilling Program), 869-893.

Barron, J. A., Baldauf, J. G., Barrera, E., Caulet, J.-P., Huber, B. T., Keating, B. H., Lazarus, D., Sakai, H., Thierstein, H. R., and Wei, W., 1991b. Biochronologic and magnetochronologic synthesis of Leg 119 sediments from the Kerguelen Plateau and Prydz Bay, Antarctica. In Barron, J., Larsen, B., et al., Proc. ODP, Sci. Results, 119: College Station, TX (Ocean Drilling Program), 813-848.

Bartek, L. R., III, 1989. Sedimentology and stratigraphy of McMurdo Sound and the Ross Sea, Antarctica: implications for glacial history and analysis of high latitude marginal basins [Ph.D. dissert.]. Rice Univ., Houston, TX.

Bartek, L. R., Sloan, L. C., Anderson, J. B., and Ross, M. I., in press. Evidence from the antarctic continental margin of late Paleogene ice sheets: a manifestation of plate reorganization and synchronous changes in atmospheric circulation over the emerging Southern Ocean? In Prothero, D. R., and Berggren, W. A. (Eds.), Eocene-Oligocene Climate and Biotic Evolution: Princeton (Princeton Univ. Press).

Bartek, L. R., Vail, P. R., Anderson, J. B., Emmet, P. A., and Wu, S., 1991. The effect of Cenozoic ice sheet fluctuations in Antarctica on the stratigraphic signature of the Neogene. J. Geophys. Res., 96(B4):6753-6778.

Benson, R. A., 1975. The origin of the psychrosphere as recorded in changes of deep-sea ostracode assemblages. Lethaia, 8:69-83.

Benson, R. H., Chapman, R. E., and Deck, L. T., 1985. Evidence from the Ostracoda of major events in the South Atlantic and world-wide over the past 80 million years. In Hsü, K. J., and 
Weissert, H. (Eds.), South Atlantic Paleoceanography: Cambridge (Cambridge Univ. Press), 325-350.

Birkenmajer, K., Deletala, M. C., Narebski, W., Nicoletti, M., and Petrucciani, C., 1986. Geochronology of Tertiary island-arc volcanics and glacigenic deposits, King George Island, South Shetland Islands (West Antarctica). Bull. Pol. Acad. Sci. Earth Sci., $34: 257-273$.

Birkenmajer, K., Dudziak, J., and Tokarski, A. K., 1988. Palaeogene calcareous nannoplankton from a neptunian dyke in the Low Head Member: its bearing on the age of the Polonez Glaciation in West Antarctica. Stud. Geol. Pol., 95:7-25.

Birkenmajer, K., and Gazdzicki, A., 1986. Oligocene age of the Pectin Conglomerate on King George Island, West Antarctica. Bull. Pol. Acad. Sci. Earth Sci., 34:219-226.

Boersma, A., 1985. Oligocene benthic foraminifers from North Atlantic sites: benthic foraminifers as water-mass indexes in the North and South Atlantic. In Bougault, H., Cande, S. C., et al., Init. Repts. DSDP, 82: Washington (U.S. Govt. Printing Office), 611627.

Breza, J. R., Wise, S. W., Jr., and Ocean Drilling Program Leg 120 Shipboard Scientific Party, 1988. Lower Oligocene ice-rafted debris on the central Kerguelen Plateau, ODP Leg 120: evidence for east Antarctica continental glaciation. Geol. Soc. Am. Abstr. Programs, 20:A69. (Abstract)

Breza, J. R., Wise, S. W., Zachos, J. C., and the ODP Leg 120 Shipboard Party, 1989. Lower Oligocene ice-rafted debris at $58^{\circ} \mathrm{S}$ on the Kerguelen Plateau: the "smoking gun" for the existence of an early Oligocene ice sheet on East Antarctica. Third Int. Conf. Paleo-oceanography, Cambridge, U.K., No. 24. (Abstract)

Broecker, W. S., 1989. The salinity contrast between the Atlantic and Pacific Oceans during glacial time. Paleoceanography, 4:207-212.

Brunn, A. F., 1957. Deep sea and abyssal depths. Mem. Geol. Soc. Am., 67:641-672.

Bukry, D., 1973. Low-latitude coccolith biostratigraphic zonation. In Edgar, N. T., Saunders, J. B., et al., Init. Repts. DSDP, 15: Washington (U.S. Govt. Printing Office), 685-703.

Ciesielski, P. F., and Weaver, F. M., 1974. Early temperature changes in the Antarctic Seas. Geology, 2:511-515.

Cisne, J. L., and Rabe, B. D., 1978. Coenocorrelation: gradient analysis of fossil communities and its applications in stratigraphy. Lethaia, 11:342-363.

Craig, H., and Gordon, L. I., 1965. Deuterium and oxygen-18 variations in the ocean and the marine atmosphere. Proc. Stable Isotopes Oceanogr. Stud. and Paleotemp., Spoleto, 2:1-87.

Denton, G. H., Armstrong, R. L., and Stuiver, M., 1971. The late Cenozoic glacial history of Antarctica. In Turekian, K. K. (Ed.), The Late Cenozoic Glacial Ages: New Haven (Yale Univ. Press), 267-306.

Denton, G. H., Prentice, M. L., and Burckle, L. H., in press. Cenozoic history of the Antarctic ice sheet. In Tingey, R. J. (Ed.), Geology of Antarctica: Oxford (Oxford Univ. Press).

Devereux, I., 1967. Oxygen isotope palaeotemperatures on New Zealand Tertiary fossils. N. Z. J. Sci., 10:988-1011.

Dorman, F. H., 1966. Australian Tertiary palaeotemperatures. J. Geol., 74:49-61.

Dowsett, H. J., and Cronin, T. M., 1990. High eustatic sea level during the middle Pliocene: evidence from the southeastern U.S. Atlantic Coastal Plain. Geology, 18:435-438.

Drewry, D. J. (Ed.), 1983. Antarctica: Glaciological and Geophysical Folio: Cambridge (Scott Polar Res. Inst.).

Edwards, A. R., and Waghorn, D. B., 1989. Calcareous nannofossils. In Barrett, P. J. (Ed.), Antarctic Cenozoic History from the CIROS-1 Drillhole, McMurdo Sound. DSIR Bull. N. Z., 245:145149.

Ehrmann, W. U., 1991. Implications of sediment composition on the Southern Kerguelen Plateau for paleoclimate and depositional environment. In Barron, J., Larsen, B., et al., Proc. ODP, Sci. Results, 119: College Station, TX (Ocean Drilling Program), 185-210.

Epstein, S. and Mayer, T., 1953. Variations in $\mathrm{O}^{18}$ content of waters from natural sources. Geochim. Cosmochim. Acta, 27:213-224.

Frakes, L. A., and Francis, J. E., 1988. A guide to Phanerozoic cold polar climates from high-latitude ice-rafting in the Cretaceous. Nature, 333:547-549.
Gazdzicka, E., and Gazdzicki, A., 1985. Oligocene coccoliths of the Pecten Conglomerate, West Antarctica. Neues Jahrb. Geol. Palaeontol. Monatsh., 12:727-735.

Gazdzicki, A., 1989. Planktonic foraminifera from the Oligocene Polonez Cove Formation of King George Island, West Antarctica. Pol. Polar Res., 10:47-55.

Grobe, H., Fütterer, D. K., and Spie $\beta$, V., 1990. Oligocene to Quaternary sedimentation processes on the Antarctic continental margin, ODP Leg 113, Site 693. In Barker, P. F., Kennett, J. P., et al., Proc. ODP, Sci. Results, 113: College Station, TX (Ocean Drilling Program), 121-131.

Haq, B. U., Hardenbol, J., and Vail, P. R., 1987. Chronology of fluctuating sea levels since the Triassic. Science, 235:1156-1167.

Haq, B. U., Okada, H., and Lohmann, G. P., 1979. Paleobiogeography of the Paleocene/Eocene calcareous nannoplankton from the North Atlantic Ocean. In Tucholke, B. E., Vogt, P. R., et al., Init. Repts. DSDP, 43: Washington (U.S. Govt. Printing Office), 617629.

Haq, B. U., Premoli-Silva, I., and Lohmann, G. P., 1977. Calcareous plankton paleobiogeographic evidence for major climatic fluctuations in the early Cenozoic Atlantic Ocean. J. Geophys. Res., 82:3861-3876.

Harwood, D. M., 1983. Diatoms from the Sirius Formation, Transantarctic Mountains. Antarct. J. U.S., 18:98-100.

1985. Late Neogene climatic fluctuations in the high southern latitudes: implications of a warm Gauss and deglaciated Antarctic continent. S. Afr. J. Sci., 81:239-241.

Harwood, D. M., Barrett, P. J., Edwards, A. R., Rieck, J. J., and Webb, P.-N., 1989a. Biostratigraphy and chronology. In Barrett, P. J. (Ed.), Antarctic Cenozoic History from CIROS-1 Drill Hole, McMurdo Sound. DSIR Bull. N. Z., 245:231-239.

Harwood, D. M., Scherer, R. P., and Webb, P.-N., 1989b. Multiple Miocene marine productivity events in West Antarctica as recorded in upper Miocene sediments beneath the Ross Ice Shelf (Site J-9). Mar. Micropaleontol., 15:91-115.

Harwood, D. M., Webb, P.-N., and Barrett, P. J., in press. Cenozoic glacial history of Antarctica: evidence for multiple glacial/deglacial cycles and marine sedimentation in Antarctic interior basins. Paleoceanography.

Harwood, D. M., Webb, P.-N., McKelvey, B. C., Mercer, J. H., and Stott, L. D., 1983. Late Neogene and Paleogene diatoms in high-elevation deposits of the Transantarctic Mountains. Geol. Soc. Am. Abstr. Programs, 20:59. (Abstract)

Hay, W. W., Mohler, H. P., and Wade, M. E., 1966. Calcareous nannofossils from Nal'chik (northwest Caucasus). Eclogae Geol. Helv., 59:379-399.

Hayes, D. E., Frakes, L. A., et al., 1975. Init. Repts. DSDP, 28: Washington (U.S. Govt. Printing Office)

Hill, R. S., 1989. Fossil leaf. In Barrett, P. J. (Ed.), Antarctic Cenozoic History from the CIROS-1 Drillhole, McMurdo Sound: DSIR Bull. N. Z., 245:143-144.

Hsü, K. J., McKenzie, J. A., Oberhänsli, H., Weissert, H., and Wright, R. C., 1984. South Atlantic Cenozoic paleoceanography. In Hsü, K.J., LaBrecque, J. L., et al., Init. Repts. DSDP, 73: Washington (U.S. Govt. Printing Office), 771-785.

Keigwin, H. D., and Corliss, B. H., 1986. Stable isotopes in late middle Eocene to Oligocene foraminifera. Geol. Soc. Am. Bull., 97:335-345.

Keigwin, H. D., and Keller, G., 1984. Middle Oligocene cooling from equatorial Pacific DSDP Site 77B. Geology, 12:16-19.

Kemp, E. M., 1978. Tertiary climatic evolution and vegetation history in the southeast Indian Ocean region. Palaeogeogr., Palaeoclimatol., Palaeoecol., 24:169-208.

Kemp, E. M., and Barrett, P. J., 1975. Antarctic glaciation and early Tertiary vegetation. Nature, 258:507-508.

Kennett, J. P., 1977. Cenozoic evolution of Antarctic glaciation, the circum-Antarctic Ocean, and their impact on global paleoceanography. J. Geophys. Res, 82:3843-3860.

1978. The development of planktonic biogeography in the Southern Ocean during the Cenozoic. Mar. Micropaleontol. 3:301-345.

Kennett, J. P., and Barker, P. F., 1990. Latest Cretaceous to Cenozoic climate and oceanographic developments in the Weddell Sea, Antarctica: an ocean-drilling perspective. In Barker, P. F., 
Kennett, J. P., et al., Proc. ODP, Sci. Results, 113: College Station, TX (Ocean Drilling Program), 937-960.

Kennett, J. P., and Shackleton, N. J., 1976. Oxygen isotopic evidence for the development of the psychrosphere $38 \mathrm{~m} . \mathrm{y}$. ago. Nature, 260:513-515.

Kennett, J. P., and Stott, L. D., 1990. Proteus and Proto-oceanus: ancestral Paleogene oceans as revealed from Antarctic stable isotopic results: ODP Leg 113. In Barker, P. F., Kennett, J. P., et al., Proc. ODP, Sci. Results, 113: College Station, TX (Ocean Drilling Program), 865-880.

Krinsley, D., and Donahue, J., 1968. Environmental interpretation of sand grain surface features by electron microscopy. Geol. Soc. Am. Bull, 79:743-748.

Kvasov, D. D., and Verbitzky, M. Y., 1981. Causes of Antarctic glaciation in the Cenozoic. Quat. Res., 15:1-17.

Leg 113 Shipboard Scientific Party, 1987. Glacial history of Antarctica. Nature, 328:115-116.

Leg 119 Shipboard Scientific Party, 1988. Early glaciation of Antarctica. Nature, 333:303-304.

Leg 120 Scientific Drilling Party, 1988. ODP at Kerguelen Plateau: Leg 120 explores origins and history. Geotimes, 33:12-16.

LeMasurier, W. E., and Rex, D. C., 1982. Volcanic record of Cenozoic glacial history in Marie Byrd Land and western Ellsworth Land: revised chronology and evaluation of tectonic factors. In Craddock, C. (Ed.), Antarctic Geoscience: Madison (Univ. Wisconsin Press), 725-734.

1983. Rates of uplift and the scale of ice level instabilities recorded by volcanic rocks in Marie Byrd Land, West Antarctica. In Oliver, R. L., James, P. R., and Jago, J. B. (Eds.), Antarctic Earth Science: Cambridge (Cambridge Univ. Press), 663-670.

Margolis, S. V., and Kennett, J. P., 1971. Cenozoic paleoglacial history of Antarctica recorded in subantarctic deep-sea cores. Am. J. Sci., 271:1-36.

Matthews, R. K., and Poore, R. Z., 1980. Tertiary $\delta^{18} \mathrm{O}$ record and glacio-eustatic sea-level fluctuations. Geology, 8:501-506.

McKelvey, B. C., Webb, P.-N., Harwood, D. M., and Mabin, M.C.G., 1987. The Dominion Range Sirius Group-a late Pliocene-early Pleistocene record of the ancestral Beardmore Glacier. 5th Int. Symp. on Antarct. Earth Sci., Cambridge, 97. (Abstract)

1991. The Dominion Range Sirius Group-a record of the late Pliocene-early Pleistocene Beardmore Glacier. In Thomson, M.R.A., Crame, J. A., and Thomson, J. W. (Eds.), Geological Evolution of Antarctica: Cambridge (Cambridge Univ. Press), 683-686.

Mercer, J. H., 1973. Cainozoic temperature trends in the southern hemisphere: Antarctic and Andean glacial evidence. In van Zinderen Bakker, E. M, (Ed.), Paleoecology of Africa and of the Surrounding Islands and Antarctica (Vol. 8): Cape Town (Balkema), 85-114.

1978. Glacial development and temperature trends in the Antarctic and in South America. In van Zinderen Bakker, E. M. (Ed.), Antarctic Glacial History and World Palaeoenvironments: Rotterdam (Balkema), 73-93.

1983. Cenozoic glaciation in the Southern Hemisphere. Annu. Rev. Earth Planet. Sci., 11:99-132.

Mildenhall, D. C., 1989. Terrestrial palynology. In Barrett, P. J. (Ed.), Antarctic Cenozoic History from CIROS-1 Drill Hole, McMurdo Sound. DSIR Bull. N. Z., 245:119-127.

Miller, K. G., and Fairbanks, R. G., 1983. Evidence for Oligocenemiddle Miocene abyssal circulation changes in the western North Atlantic. Nature, 306:250-252.

Miller, K. G., Fairbanks, R. G., and Mountain, G. S., 1987. Tertiary oxygen isotope synthesis, sea level history, and continental margin erosion. Paleoceanography, 2:1-19.

Miller, K. G., Kent, D. V., Brower, A. N., Bybell, L. M., Feigenson, M. D., Olsson, R. K., and Poore, R. Z., 1990. Eocene-Oligocene sea-level changes on the New Jersey coastal plain linked to the deep-sea record. Geol. Soc. Am. Bull., 102:331-339.

Miller, K. G., Mountain, G. S., and Tucholke, B. E., 1985. Oligocene glacio-eustasy and erosion on the margins of the North Atlantic. Geology, 13:10-13.

Miller, K. G., and Thomas, E., 1985. Late Eocene to Oligocene benthic foraminiferal isotopic record, Site 574, equatorial Pacific.
In Mayer, L., Theyer, F., Thomas, E., et al., Init. Repts. DSDP, 85: Washington (U. S. Govt. Printing Office), 771-777.

Mix, A. C., 1987. The oxygen isotope record of glaciation. In Ruddiman, W. F., and Wright, H. E. (Eds.), North America and Adjacent Oceans During the Last Glaciation. Geol. Soc. Am., Geol. North Am., K-3:111-135.

Mix, A. C., and Ruddiman, W. F., 1984. Oxygen-isotope analyses and Pleistocene ice volumes. Quat. Res., 21:1-20.

Muza, J. P., Williams, D. F., and Wise, S. W., Jr., 1983. Paleogene oxygen isotope record for Deep Sea Drilling Project Sites 511 and 512, subantarctic South Atlantic Ocean: paleotemperatures, paleoceanographic changes, and the Eocene/Oligocene boundary event. In Ludwig, W. J., Krasheninnikov, V. A., et al., Init. Repts. DSDP, 71, Pt. 1: Washington (U.S. Govt. Printing Office), 409422.

Oberhänsli, H., McKenzie, J. A., Toumarkine, M., and Weissert, H., 1984. A paleoclimatic and paleoceanographic record of the Paleogene in the central South Atlantic (Leg 73, Sites 522, 523, 524). In Hsü, K. J., LaBrecque, J. L., et al., Init. Repts. DSDP, 73; Washington (U.S. Govt. Printing Office), 737-748.

Oberhänsli, H., and Toumarkine, M., 1985. The Paleogene oxygen and carbon isotope history of Sites 522, 523, and 524 from the central South Atlantic. In Hsü, K. J., and Weissert, H. J. (Eds.), South Atlantic Paleoceanography: Cambridge (Cambridge Univ. Press), 125-147.

Oerlemans, J., 1982. A model of the Antarctic ice sheet. Nature, 297:500-553.

Perch-Nielsen, K., 1985. Cenozoic calcareous nannofossils. In Bolli, H. M., Saunders, J. B., and Perch-Nielsen, K. (Eds.), Plankton Stratigraphy: Cambridge (Cambridge Univ. Press); 427-554.

Peterson, C., 1991. Leafing through Antarctica's balmy past. New Scient., 129:20.

Poore, R. Z., and Matthews, R. K., 1984. Oxygen isotope ranking of late Eocene and Oligocene planktic foraminifers: implications for Oligocene sea-surface temperatures and global ice-volume. Mar. Micropaleontol., 9:111-134.

Pospichal, J. J., and Wise, S. W., Jr., 1990. Paleocene to middle Eocene calcareous nannofossils of ODP Sites 689 and 690, Maud Rise, Weddell Sea. In Barker, P. F., Kennett, J. P., et al., Proc. ODP. Sci. Results, 113: College Station, TX (Ocean Drilling Program), 613-638.

Prentice, M. L., and Matthews, R. K., 1988. Cenozoic ice-volume history: development of a composite oxygen isotope record. Geology, 16:963-966.

Robert, C., and Maillot, H., 1990. Paleoenvironments in the Weddell Sea area and Antarctic climates, as deduced from clay mineral associations and geochemical data, ODP Leg 113. In Barker, P. F., Kennett, J. P., et al., Proc. ODP, Sci. Results, 113: College Station, TX (Ocean Drilling Program), 51-70.

Rye, N. M., and Sommer, M. A., II., 1980. Reconstruction of paleotemperature and paleosalinity regimes with oxygen isotopes. In Rhoads, D. C., and Lutz, R. A. (Eds.), Skeletal Growth of Aquatic Organisms: New York (Plenum), 169-202.

Sancetta, C., 1979. Paleogene Pacific macrofossils and paleoceanography. Mar. Micropaleontol., 4:363-398.

Savin, S. M., 1977. The history of the earth's surface temperature during the past 100 million years. Annu. Rev. Earth Planet. Sci., $5: 319-355$

Savin, S. M., Douglas, R. G., and Stehli, F. G., 1975. Tertiary marine paleotemperatures. Geol. Soc. Am. Bull., 86:1499-1510.

Schlich, R., Wise, S. W., Jr., et al., 1989. Proc. ODP, Init. Repts., 120: College Station, TX (Ocean Drilling Program).

Scotese, C. R., Gahagan, L. M., and Larson, R. L., 1988. Plate tectonic reconstructions of the Cretaceous and Cenozoic ocean basins. Tectonophysics, 155:27-48.

Shackleton, N. J., 1986. Paleogene stable isotope events. Palaeogeogr., Palaeoclimatol., Palaeoecol., 57:91-102.

Shackleton, N. J., and Boersma, A., 1981. The climate of the Eocene ocean. J. Geol. Soc. London, 138:153-157.

Shackleton, N. J., Hall, M. A., and Boersma, A., 1984. Oxygen and carbon isotope data from Leg 74 foraminifers. In Moore, T. C., Jr., Rabinowitz, P. D., et al., Init. Repts. DSDP, 74: Washington (U.S. Govt. Printing Office), 599-644. 
Shackleton, N. J., and Kennett, J. P., 1975. Paleotemperature history of the Cenozoic and the initiation of Antarctic glaciation: oxygen and carbon isotope analyses in DSDP Sites 227,279 , and 281. In Kennett, J. P., Houtz, R. E., et al., Init. Repts. DSDP, 29 : Washington (U.S. Govt. Printing Office), 743-756.

Shipboard Scientific Party, 1990. Introduction, background, and principal results of Leg 128 of the Ocean Drilling Program, Japan Sea. In Ingle, J. C., Jr., Suyehiro, K., von Breymann, M. T., et al., Proc. ODP, Init. Repts., 128: College Station, TX (Ocean Drilling Program), 5-38.

Sloan, L. C., and Barron, E. J., 1990. Equable climates during Earth history. Geology, 18:489-492.

Stott, L. D., Kennett, J. P., Shackleton, N. J., and Corfield, R. M., 1990. The evolution of Antarctic surface waters during the Paleogene: inferences from stable isotopic composition of planktonic foraminifers, ODP Leg 113. In Barker, P. F., Kennett, J. P., et al., Proc. ODP, Sci. Results, 113: College Station, TX (Ocean Drilling Program), 849-863.

Thomas, E., 1990. Late Cretaceous through Neogene deep-sea benthic foraminifers (Maud Rise, Weddell Sea, Antarctica). In Barker, P. F., Kennett, J. P., et al., Proc. ODP, Sci. Results, 113: College Station, TX (Ocean Drilling Program), 571-594. in press. Middle Eocene-late Oligocene bathyal benthic foraminifera (Weddell Sea): faunal changes and implications for ocean circulation. In Prothero, D. A., and Berggren, W. A. (Eds.), Eocene-Oligocene Climatic and Biotic Evolution: Princeton(Princeton Univ. Press).

Vail, P. R., Mitchum, R. M., Jr., Todd, R. G., Widmier, J. M., Thompson, S., III, Sangree, J. B., Bubb, J. N., and Hatelid, W. G., 1977. Seismic stratigraphy and global changes of sea level. In Payton, C. E. (Ed.), Seismic Stratigraphy-Applications to Hydrocarbon Exploration: AAPG Mem., 26:49-221.

Warnke, D. A., 1970. Glacial erosion, ice rafting, and glacial marine sediments: Antarctica and the Southern Ocean. Am. J. Sci., 269:276-294.

Webb, P.-N., 1990. The Cenozoic history of Antarctica and its global impact. Antarct. Sci., 2:2-21.

Webb, P.-N., and Harwood, D. M., 1987. Terrestrial flora of the Sirius Formation: its significance for late Cenozoic glacial history. Antarct. J. U.S., 22:7-11.

Webb, P.-N., Harwood, D. M., McKelvey, B. C., Mercer, J. H., and Stott, L.D., 1983. Late Neogene and older Cenozoic microfossils in high elevation deposits of the Transantarctic Mountains: evidence for marine sedimentation and ice volume variation on the East Antarctic craton. Antarct. J. U.S., 18:96-97.

1984. Cenozoic marine sedimentation and ice-volume variation on the East Antarctic craton. Geology, 12:287-291.

Wei, W., and Thierstein, H. R., 1991. Upper Cretaceous and Cenozoic calcareous nannofossils of the Kerguelen Plateau (southern Indian Ocean) and Prydz Bay (East Antarctica). In Barron, J., Larsen, B. et al., Proc. ODP, Sci. Results, 119: College Station, TX (Ocean Drilling Program), 467-494.

Wei, W., and Wise, S. W., Jr., 1990a. Biogeographic gradients of middle Eocene-Oligocene calcareous nannoplankton in the South Atlantic Ocean. Palaeogeogr., Palaeoclimatol., Palaeoecol., 79:29-61.

1990b. Middle Eocene to Pleistocene calcareous nannofossils recovered by Ocean Drilling Program Leg 113 in the Weddell Sea. In Barker, P. F., Kennett, J. P., et al., Proc. ODP, Sci.
Results, 113: College Station, TX (Ocean Drilling Program), 639-666.

in press. Latitudinal biogeographic gradient of late Paleogene calcareous nannoplankton in the South Atlantic Ocean. Proc. Int. Nannoplankton Assoc. Meeting, Florence, 1989. Mem. Sci. Geol., Univ. Padova.

Williams, D. F., Thunell, R. C., Hodell, D. A., and VergnaudGrazzini, C., 1985. Synthesis of late Cretaceous, Tertiary, and Quaternary stable isotope records of the South Atlantic based on Leg 72 DSDP core material. In Hsü, K. J., and Weissert, H. (Eds.), South Atlantic Paleoceanography: Cambridge (Cambridge Univ. Press), 283-324.

Wise, S. W., Gombos, A. M., and Muza, J. P., 1985. Cenozoic evolution of polar water masses, southwest Atlantic Ocean. In Hsü, K. J., and Weissert, H. (Eds.), South Atlantic Paleoceanography: Cambridge (Cambridge Univ. Press), 205-241.

Wise, S. W., Jr., 1988. Mesozoic-Cenozoic history of calcareous nannofossils in the region of the Southern Ocean. Palaeogeogr., Palaeoclimatol., Palaeoecol., 65:157-179.

Wise, S. W., Jr., Breza, J. R., Harwood, D. M., and Wei, W., 1991. Paleogene glacial history of Antarctica. In McKenzie, J. A., Müller, D. W., and Weissert, H. (Eds.), Controversies in Modern Geology: Cambridge (Cambridge Univ. Press).

Wise, S. W., Jr., Hay, W. W., O'Connell, S., Barker, P. F., Kennett, J. P., Burckle, L. H., Egeberg, P. K., Fütterer, D. K., Gersonde, R. E., Golovchencko, X., Hamilton, N., Lazarus, D. B., Mohr, B., Nagao, T., Pereira, C.P.G., Pudsey, C. J., Robert, C. M., Schlandl, E., Spie $\beta$, V., Stott, L. D., Thomas, E., and Thompson, K.F.M., 1987. Early Oligocene ice on the Antarctic continent. Geol. Soc. Am. Abstr. Programs, 19:893. (Abstract)

Woodruff, F., Savin, S. M., and Douglas, R. G., 1981. Miocene stable isotope record: a detailed deep Pacific Ocean study and its paleoclimatic implications. Science, 212:665-668.

Zachos, J. C., Breza, J., and Wise, S. W., 1989. A high latitude, southern Indian Ocean middle Eocene to Oligocene Paleoclimatic record. Eos, 15:375. (Abstract)

Zinsmeister, W. J., 1978. Effect of formation of the West Antarctic ice sheet on shallow water marine faunas of Chile. Antarct. J. U.S., $13: 25-26$.

Date of initial receipt: 27 October 1990

Date of acceptance: 1 May 1991

Ms 120B-205

\section{APPENDIX}

\section{Occurrence of Lower Oligocene Ice-rafted Debris} on the Southern Kerguelen Plateau

Lower Oligocene ice-rafted debris has been recorded at three ODP drill sites on the Southern Kerguelen Plateau. Those occurrences at Sites 738,744 , and 748 are diagrammed on the age-depth plots in Figures 24-26, which can be considered as age models for the IRD events. According to these plots, Sites 744 and 748 probably record the same event, which occurred just within $35.8-36.0 \mathrm{Ma}$ (at the top of Subchron 13R and the lowermost part of $13 \mathrm{~N}$ ). The record at southernmost Site 738 , is dated slightly younger, at about $35 \mathrm{Ma}$. If these age models are correct, then two distinct ice-rafting events are recorded on the plateau for the lower Oligocene. 


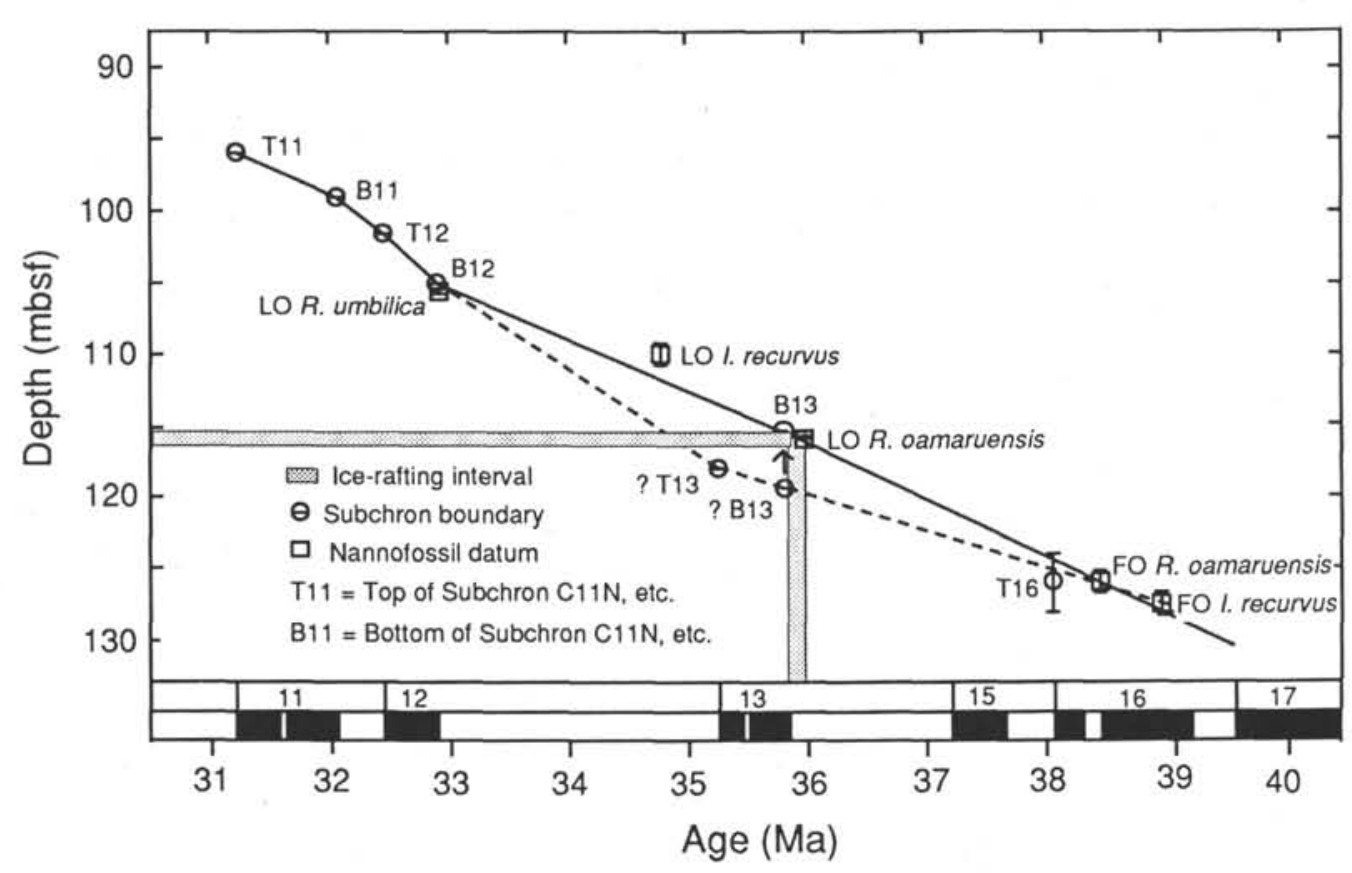

Figure 24. Age-depth curve for the upper Eocene-lower Oligocene interval at Site 748 based on magnetostratigraphy and calcareous nannofossil datums. Dashed lines are based on the previous magnetostratigraphic interpretation given in Schlich, Wise, et al. (1989); solid lines indicate the interpretation of Wei et al. (this volume), which better fits the nannofossil data. Ice-rafting interval described by Breza and Wise (this volume) at this site is indicated by shaded line (from Wei et al., this volume). $\mathrm{LO}=$ last occurrence, FO $=$ first occurrence.

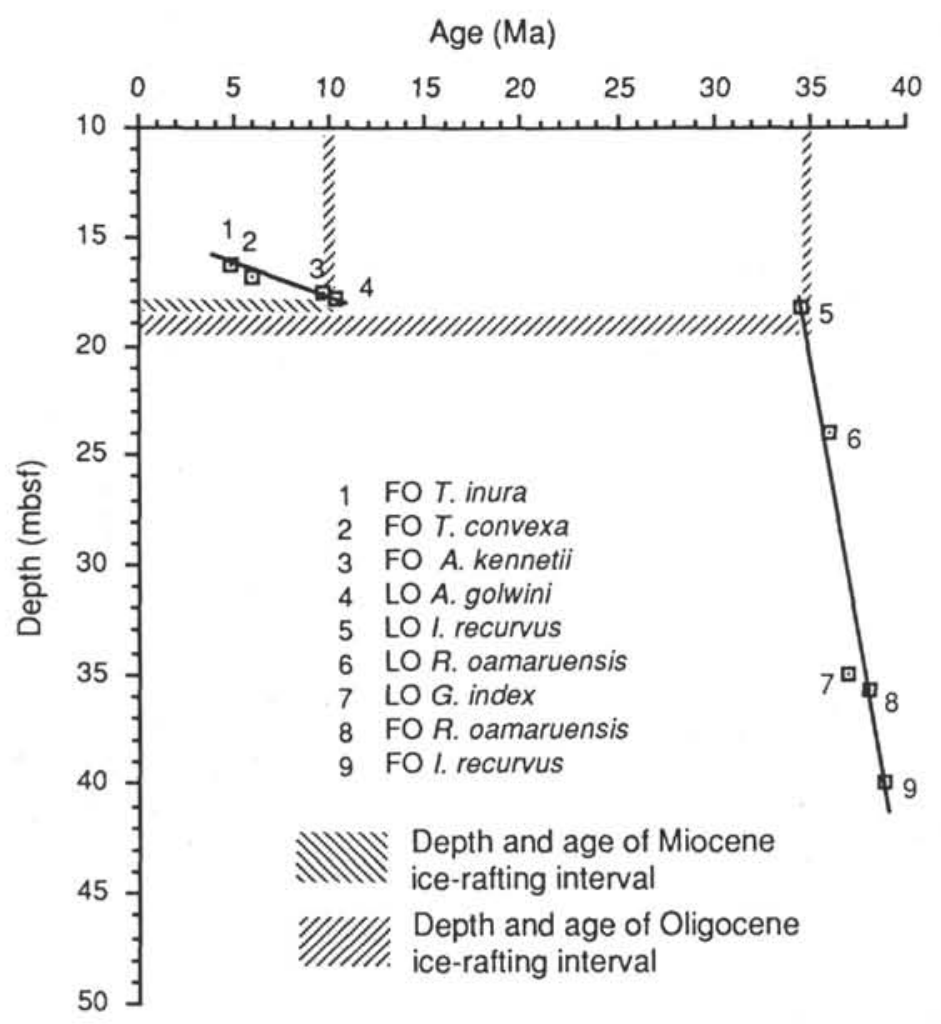

Figure 25. Age-depth curve for Site 738 showing nannofossil abundances and interval containing ice-rafted debris highlighted by hatched lines (after Wei, this volume, Chapter 64). 


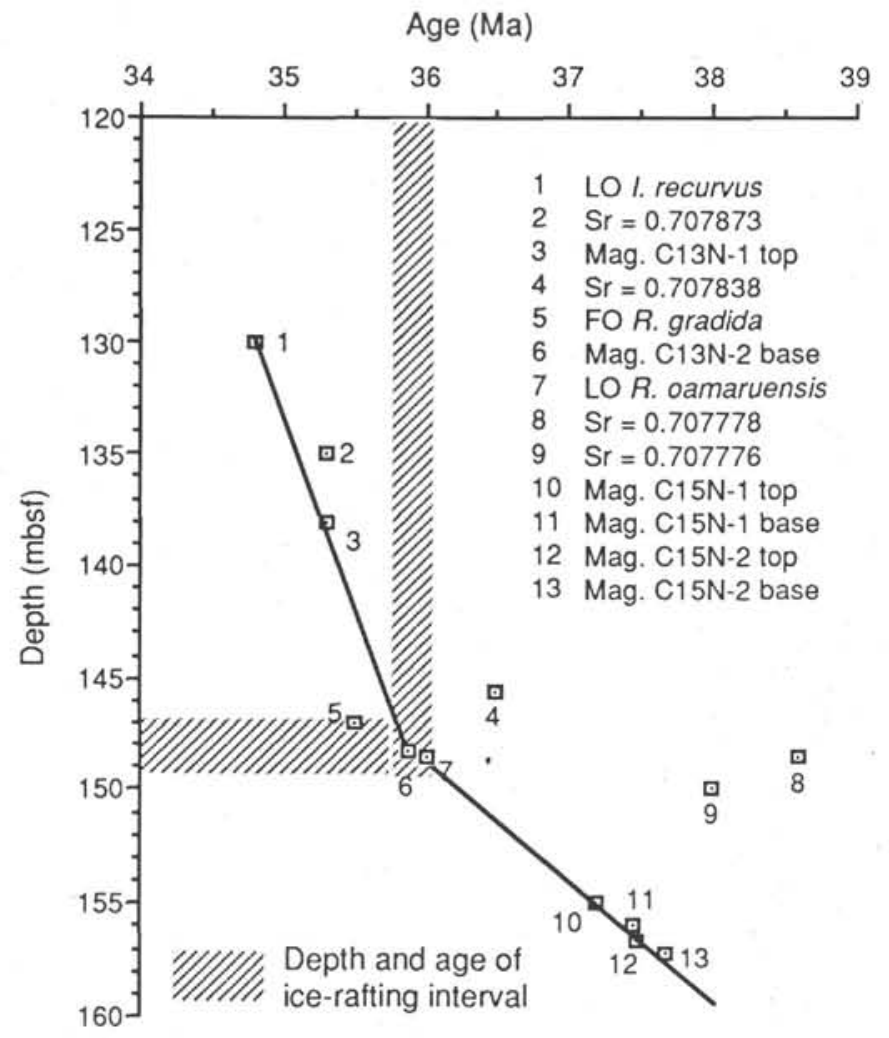

Figure 26. Age-depth curve for Site 744 showing nannofossil abundances and interval containing IRD (after Wei, this volume, Chapter 64). 